UNIVERSIDADE DE SÃO PAULO

FACULDADE DE FILOSOFIA, LETRAS E CIÊNCIAS HUMANAS DEPARTAMENTO DE LINGÜÍSTICA

EM TORNO DA NARRATIVA NARRAÇÃO: A PROPOSTA REVISITADA DO MODELO LABOVIANO DE NARRATIVA ORAL

Priscila Peixinho Fiorindo

São Paulo

2005 
UNIVERSIDADE DE SÃO PAULO

FACULDADE DE FILOSOFIA, LETRAS E CIÊNCIAS HUMANAS

DEPARTAMENTO DE LINGÜÍSTICA

EM TORNO DA NARRATIVA NARRAÇÃO: A PROPOSTA REVISITADA DO MODELO LABOVIANO DE NARRATIVA ORAL

Priscila Peixinho Fiorindo

Dissertação de Mestrado apresentada ao Departamento de Lingüística da Faculdade de Filosofia, Letras e Ciências Humanas da Universidade de São Paulo, sob a orientação da Prof $^{a}$ Dr $^{\mathrm{a}}$ Lélia Erbolato Melo.

São Paulo 


\section{AGRADECIMENTOS}

À Professora Doutora Lélia Erbolato Melo, pela atenção e disponibilidade sempre oferecidas, pelas discussões teóricas e conversas, que tanto contribuíram para o meu crescimento acadêmico e profissional.

Às Professoras Doutoras Elisa Guimarães e Ana Paula Mac-kay, pelas sugestões e indicações que me forneceram no momento do Exame de Qualificação.

Às colegas de equipe do Grupo de Pesquisa em Psicolingüística, GPPL, pelas contribuições teóricas apresentadas e discutidas em reuniões mensais.

Aos meus pais, Máximo e Luiza, pela compreensão e descontração nos momentos difíceis de criação deste trabalho.

Às seis crianças das pré-escolas, que forneceram os dados para que esta pesquisa se realizasse. 
Há maior significado profundo nos contos de fada que me contaram na infância do que na verdade que a vida ensina.

SCHILLER 


\section{RESUMO}

Partindo da idéia de que não há oposição fundamental entre explicação e narração, pois ao contar uma história explicamos e, ao explicar, legitimamos o caráter memorável daquilo que contamos, elegemos como objeto de estudo a relação entre compreensão e produção de histórias orais em seis crianças, de cinco anos, de ambos os sexos, observando o papel da avaliação (Labov, 1972), bem como para identificar a articulação dos processos narrativo/explicativo presentes nas produções infantis. Para tanto, propomos uma análise de narrativa, a partir do modelo apresentado por Labov, mas procedendo de modo diferente do autor, uma vez que ele se ocupou das narrativas de experiências pessoais, onde os locutores se preocupam em reconstruir, até em reviver fatos de seu passado. Nesta perspectiva, adaptamos este modelo de narrativa com o olhar voltado para as histórias orais elaboradas pelas crianças. De acordo com o autor, a avaliação é um dos elementos estruturais da narrativa que tem por finalidade comunicar ao ouvinte o ponto de vista do narrador em relação à história por ele narrada, ou seja, a função avaliativa diz respeito à necessidade que tem o locutor de manter o interesse do interlocutor durante a narração. Considerando que é nosso objetivo estabelecer uma relação entre o narrar e o explicar com base no procedimento da avaliação (Labov), nos apoiamos em alguns autores (Hudelot et al. Veneziano, Halté entre outros) que tratam da explicação. Segundo Hudelot et al. (2003), o termo "explicação" remete a um universo de sentidos, pois para explicar o significado de uma palavra ou de uma ação, é necessário analisar o contexto e o sentido da mesma, de modo que seja possível torná-la inteligível para o interlocutor. Leclaire-Halté (1990) afirma que a explicação, em textos de ficção, surge quando há um problema que deve ser resolvido. Assim, observamos e contrastamos duas situações: (a) produção de histórias orais a partir de desenhos feitos pelas crianças; e (b) a produção de narrativas a partir das histórias lidas pela pesquisadora, apoiando-nos para isso em autores que tratam tanto da comunicação verbal, como da comunicação não-verbal. As conclusões confirmam que, embora as histórias elaboradas nas duas situações apresentem características distintas da linguagem oral e escrita, ambas mantêm em comum a articulação do explicar e do narrar.

Palavras-chave: criança; linguagem oral; narrativa; explicação 


\begin{abstract}
From the idea that there is no fundamental opposition between explanation and narration, because when one tells a story one explains it and explaining we legitimize the memorable character of what we tell, we've elected as the object of our study, the comprehension and production of oral stories in six children of five years old, of both genders, observing the role of the evaluation (Labov,1972) as well as to identify the articulation of narrative/explicative processes present in the children's production. For that, we propose an analysis of the narrative starting from the model presented by Labov, but proceeding in a different way from that of author once he's been dealing with the narratives of personal experience in which the locutor are worried about reconstructing or even reliving facts of their past. In this perspective, we've adapted this model of narrative looking at the oral stories produced by the children. According to the author, the evaluation is one of the structural elements of the narrative which has as its aim communicate to the listener the point of view of the narrator in relation to the story narrated by him, in other words, the evaluative function is concerned about the necessity that the locutor has of keeping the interest of the interlocutor along the narration. Considering that it's our objective to establish a relation between the narrating and explaining based on the procedure of evaluation (Labov), we've found support in some authors (Hudelot et al., Veneziano, Halté among others) that work with explanation. According to Hudelot et al. (2003), the term "explanation" refer a universe of senses, that is to explain the meaning of a word or action it's necessary to analyses its context and sense that it's possible to make the word or action intelligible to the interlocutor. Leclaire-Halté (1990) states that the explanation in fiction texts, arises when there is a problem that must be solved. This way, we've observed and contrasted two situations: (a) production of oral stories through drawings done by the children; and (b) the production of narratives through the stories read by the researcher being supported by authors that deal with both the verbal communication and the non-verbal communication. The conclusions confirm that although the produced stories in both situations present distinct characteristics of oral and written language, both keep the articulation of explaining and narrating in common.
\end{abstract}

Key words: children; oral language; narrative; explanation 


\section{APRESENTAÇÃO PESSOAL}

O interesse pela Psicolingüística surgiu ainda durante a graduação em Letras, mais especificamente, após a elaboração do T.G.I. - Trabalho de Graduação Interdisciplinar, sobre "A didática do conto maravilhoso e desenvolvimento da imaginação", apresentado, em 2001, na Universidade Presbiteriana Mackenzie.

A partir de então, a necessidade de um maior entendimento do processo de aquisição e desenvolvimento da linguagem, foi se tornando cada vez mais evidente para nós, o que nos motivou a dar continuidade aos estudos nesta área, passando por uma seleção com a Prof ${ }^{a} \operatorname{Dr}^{\mathrm{a}}$ Lélia Erbolato Melo, no Programa de Pós-Graduação em Lingüística. Ingressando na Pós-Graduação, ao concluir as disciplinas e realizado o Exame de Qualificação (agosto de 2004), novas perspectivas em relação à compreensão e produção de narrativas pelas crianças pequenas surgiram.

Tendo em vista que o processo de formação de um leitor começa bem antes de ele aprender a decodificar a leitura a partir do texto escrito, o início deste caminho e a sedução pelo mesmo se dão ainda no berço, através dos acalentos e parlendas e, claro, da ambiência de afeto que este processo propicia.

A partir das cantigas de ninar, a criança vai criando ferramentas para se tornar leitor e identificar a espinha dorsal de uma narrativa para reproduzi-la. As histórias não só ensinam como também nos convidam a olhar para dentro, pois apresentam os percalços e deleites que a vida nos reserva.

Considerando o relato, com base em conversas com a orientadora, levando em conta nossa experiência como professora de Língua Portuguesa, no Ensino Fundamental e Médio, na Rede Pública do Estado de São Paulo, percebemos que contar e ouvir histórias são processos de uma arte sem idade, o que confirma o ditado popular: "de uma boa história ninguém escapa".

A partir daí, o interesse em investigar de maneira mais profunda as peculiaridades do desenrolar narrativo, em crianças de cinco anos, aumentou, pois nessa faixa etária, de acordo com Gardner (1994), elas já possuem uma capacidade simbólica 
que permite a elaboração de histórias orais. Nesta perspectiva, temos o propósito de verificar como se processa a articulação entre o narrar e o explicar, tomando como referência o modelo laboviano de narrativa oral. 


\section{SUMÁRIO}

Introdução .08

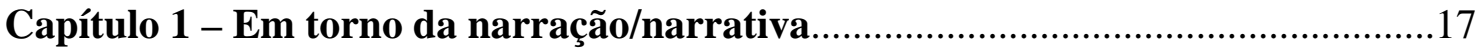

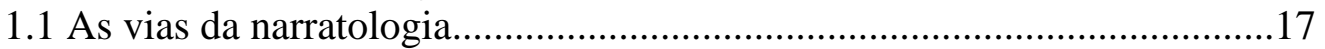

1.2 Algumas perspectivas teóricas sobre o texto narrativo.............................19

1.3 O contar no contexto da Psicanálise...........................................................33

1.4 A função semiótica ou simbólica na criança............................................36

Capítulo 2 - Compreensão e produção na criança...................................................42

$2.1 \mathrm{O}$ papel da memória no processamento do discurso...................................42

2.2 Alguns estudos sobre compreensão e produção..........................................49

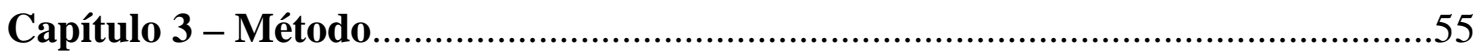

3.1 Procedimento adotado na coleta dos dados e escolha do material.............55

3.2 Seleção dos sujeitos.........................................................................56

3.3 Esclarecimentos complementares..........................................................58

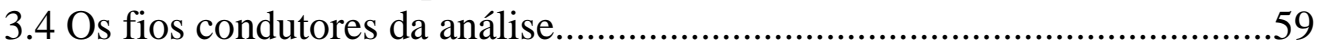

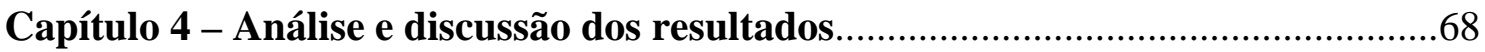

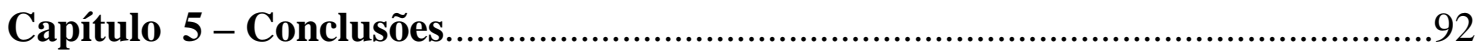

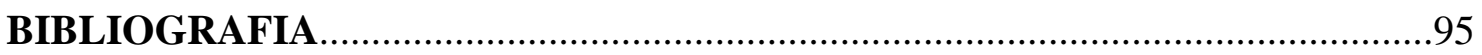

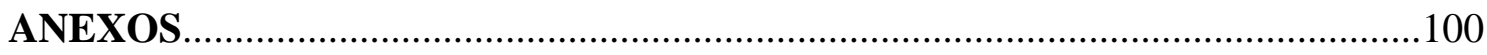

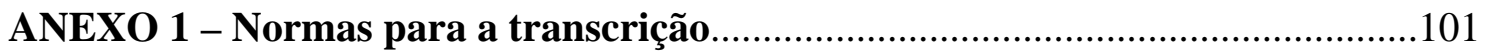

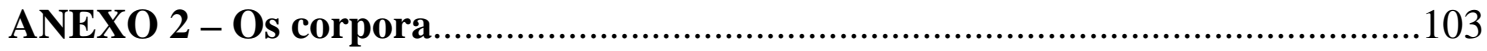

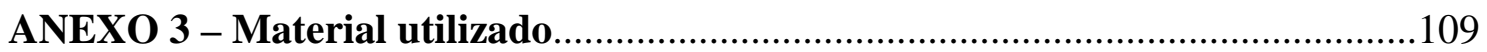

ANEXO 4 - Produção pictográfica dos sujeitos..................................................113 


\section{INTRODUÇÃO}

Considerando que a narrativa é inerente à cultura e que através dela podemos conhecer e desvendar os mistérios que envolvem o ser humano, ela torna-se indispensável ao estudo da evolução cognitiva e lingüística na criança pequena.

A fim de justificarmos o tema em questão, seguem alguns estudos sobre o percurso do desenvolvimento narrativo na criança.

Hudson e Shapiro (1991 apud Spinillo, 2001:76), observaram a produção de narrativas diversas: relatos de experiência pessoal, scripts e histórias de crianças de 4, 6 e 8 anos; a partir daí perceberam que a produção das histórias pelas crianças de oito anos apresentam estrutura narrativa elaborada, contendo - introdução, situaçãoproblema, resolução e um final coerente; as de seis anos apresentam apenas duas categorias da estrutura narrativa - uma situação-problema e um final; e as de quatro anos não mencionam nenhuma dessas características. Como vemos, estes resultados indicam uma progressão na habilidade de produzir histórias que está associada ao aumento da idade.

Rego (1986), a partir da análise de histórias escritas por crianças de $6-7$ anos, identificou diferentes níveis de desenvolvimento na aquisição de um esquema narrativo de história: categoria I (introdução); categoria II (introdução e esboço de uma situaçãoproblema); categoria III (introdução, desfecho e resolução da situação - problema); e categoria IV (estrutura narrativa elaborada).

Spinillo e Pinto (1994), adotando as categorias descritas acima, observaram a produção de histórias de crianças com idades entre 4 e 8 anos e obtiveram os seguintes resultados: as crianças de 4 e 5 anos produzem histórias classificadas nas categorias I (introdução) e II (introdução e uma situação-problema); as crianças entre 6 e 7 anos apresentam produções bastante variadas, entre as categorias II e IV (estrutura narrativa elaborada); e as de 8 anos produzem histórias completas descritas na categoria IV.

Com base nos resultados obtidos, é possível pensar que as variações encontradas nas produções das crianças de 6 e 7 anos possam ser decorrentes do processo formal de alfabetização que elas se encontram, pois as autoras verificaram que crianças da mesma 
idade em séries distintas se diferenciam quanto à qualidade narrativa de suas histórias: as melhores produções eram das crianças alfabetizadas.

Entretanto, mesmo mantendo-se constantes a idade e a escolaridade, Rego (1986) observa grandes variações nas histórias produzidas por crianças recémalfabetizadas. Uma explicação para isso é que a qualidade narrativa das histórias depende, também, de experiências e oportunidades que as crianças têm com as mesmas no ambiente familiar.

Neste sentido, vale mencionar a investigação conduzida por Lins e Silva e Spinillo (1998), baseada na observação de produções de histórias entre crianças de classe média, que interagem ativamente com a linguagem dos textos no âmbito familiar, e as crianças de baixa renda, não expostas às mesmas experiências em casa.

As autoras constataram que, em ambos os grupos (da classe média e de renda baixa), após a alfabetização existe uma progressão na escrita de histórias e que esta habilidade é mais visível nos anos escolares posteriores ao primeiro ano (início da alfabetização). Apesar dessas semelhanças nos dois grupos verificou-se que, após alguns anos de escolaridade, as crianças de classe média apresentam um maior domínio de um esquema narrativo de história em relação às crianças de baixa renda.

De acordo com Massini-Cagliari (1997), para existir a produção de um esquema narrativo completo devemos levar em consideração dois fatores: a coesão e a coerência.

A coerência, de maneira geral, é um fenômeno diretamente ligado à interlocução, enquanto que a coesão encontra-se no nível formal do texto, estabelecendo diversas relações semânticas entre os elementos desse texto.

Para Kock (1989), o conceito de coesão textual “diz respeito a todos os processos de seqüêncialização que asseguram ou tornam recuperável uma ligação lingüística significativa entre os elementos que ocorrem na superfície textual".

A noção de coerência é mais abrangente, pois é estabelecida na interação da interlocução, numa situação comunicativa entre dois usuários da língua. Pode ser vista, neste sentido, como um princípio de interpretabilidade do texto, "ligada à intelegibilidade dele numa situação de comunicação, é a capacidade que o receptor da mensagem (que a interpreta para compreendê-la) tem para calcular o seu sentido" (Kock \& Travaglia, 1989:105). 
Além disso, a coerência também é vista como uma continuidade de sentidos perceptível no texto, possibilitando a criação de um mundo textual de acordo com o conhecimento de mundo registrado na memória. Este conhecimento de mundo e o conhecimento lingüístico serão abordados a seguir quando estivermos tratando da relação entre compreensão e produção na linguagem infantil.

Embora haja um grande número de estudos sobre o desenvolvimento de habilidades para a construção de narrativas na criança, podemos ver que esta capacidade de produzir histórias, até hoje, tem sido discutida em função de aspectos relativos à própria criança: idade, escolaridade, classe social e experiências com textos.

Portanto, a fim de ampliar os estudos nessa área, acreditamos que é relevante considerar outros aspectos quando se avalia o conhecimento que a criança tem sobre histórias, como por exemplo, as situações em que ela é solicitada a produzi-las; como se processa a articulação entre o narrar e o explicar os eventos da história; como o narrador se posiciona durante o ato narrativo.

Neste trabalho a intenção é articular as peculiaridades dos processos narrativo e explicativo, nas histórias infantis, para tanto, abordamos a seguir alguns aspectos relativos à explicação na criança pequena.

Alguns autores como Hudelot, Prenéron \& Orvig (2003) afirmam que o termo "explicação" remete a um universo de sentidos, ou seja, para explicar o significado de uma palavra ou de uma ação, é necessário analisar o contexto e o sentido da mesma, de modo que seja possível torná-la inteligível para o interlocutor.

Os modos de explicação variam, mais freqüentemente, em função dos objetos, de forma que explicamos de várias maneiras os procedimentos adotados em uma determinada situação, ou um sentimento individual e particular, que partilhamos com alguém. Assim, a interlocução infantil mobiliza a criança para a compreensão e domínio de suas relações com os objetos e eventos cotidianos, transformando o mundo ao seu redor num local seguro e previsível. Dessa forma, o discurso explicativo só pode ser considerado em um contexto que tenha relações com outros discursos, e na situação que o determina.

De acordo com Veneziano et al. (2003), a criança começa a sentir necessidade de explicar ao outro as razões de seu próprio comportamento, principalmente quando há 
conflitos entre as intenções da criança e as do outro, e com isso ela introduz uma nova dimensão funcional à comunicação verbal.

As primeiras explicações - situações de pedidos de ajuda - são justificadas pela criança aumentando suas chances de alcançá-los. Outra situação que suscita atos explicativos é a do jogo de ficção, ocorrências em que a criança constrói sozinha este jogo, mas sente necessidade de explicar à mãe a razão de sua ação no jogo ou de certos acontecimentos fictícios. Como vemos a explicação não está diretamente ligada à obtenção de um objetivo próprio.

A relação que a criança tem com o mundo (no que se refere ao nível da prática ou da significação que compõe sua cultura) e com a língua, enquanto modo de decodificação de experiência é diferente se comparado ao adulto. Por isso não se pode usar as mesmas categorias de análise para o estudo do discurso oral na criança.

Neste sentido, a explicação poderia preencher a distância discursiva entre os interlocutores, uma vez que esta se dá, também, por meio das misturas de mundos - nas quais se caracterizam muitas explicações (Hudelot; Préneron e Orvig, 2003).

Ainda de acordo com os autores, é possível dizer que a criança é mais "explicadora" que o adulto devido ao prazer em exibir suas novas descobertas e conquistas. É nesta misturas de universos discursivos que a criança é capaz de dar explicações, quando solicitada e pode produzir variadas condutas explicativas que aparecem sob a forma que os adultos conhecem ("por que...", "porque", "como" etc), ou que só aparecem no confronto com discursos produzidos anteriormente por essa criança.

Se verificarmos a diversidade dos fenômenos ligados à explicação, observamos que existem critérios formais que geram situações nas quais a conduta explicativa se torna inevitável.

Dessa forma, explicar é de fato fazer-se compreender, re-elaborar significações que não existem num espaço dialógico comum entre a criança e o seu interlocutor.

Há três grandes categorias no enunciado explicativo da criança (Hudelot; Préneron e Orvig, op. cit.:32):

1) inicialmente, temos uma relação de justificação ou explicação, em que a ocorrência é devido às perguntas de um adulto; 
2) as explicações espontâneas emergem de um diálogo, onde a criança cria seu mundo com base em sua cultura;

3) finalmente, a própria criança é quem solicita as explicações, através de pedidos de confirmação do adulto.

Assim, podemos considerar duas tipologias para o comportamento explicativo: o pragmático - em que o sentido se encontra na atividade prática, ou na própria interação; e o discursivo - em que a dimensão do discurso faz com que os encadeamentos não aconteçam apenas no campo da ação, mas na partilha de significações. Este segundo tipo de comportamento explicativo (discursivo) também se mostra presente na existência de um problema, um conflito, que deve ser solucionado. Tal dimensão é bastante complexa e envolve outros tipos de conduta como a descrição ou narração.

A seguir, abordamos a explicação juntamente com a narração para verificarmos como os aspectos explicativo e narrativo se relacionam nas histórias de ficção.

De acordo com Leclaire-Halté (1990), a argumentação e a explicação, em textos de ficção, fazem parte das estratégias discursivas. Verificamos estes recursos em uma passagem extraída das primeiras obras de Jules Verne, "Viagem ao centro da Terra"; considerando L (Lindenbrock) e A (Axel):

L1: (...) - Siga-me sobre a costa ocidental da Islândia. Você percebe Reykjawik, sua capital?

A2:- Sim.

L3:- Bem, observe os inumeráveis fjords (golfo escondido das terras escandinavas), destas margens desgastadas pelo mar e pare um pouco embaixo de 65 graus de latitude. O que você vê lá?

A4: - Uma espécie de península semelhante a um osso descarnado, que termina em uma enorme rótula.

L5: - A comparação é justa, meu garoto; agora, você não vê nada sobre esta rótula?

A6: - Sim, um monte que parece ter parado no mar.

L7: - Bem! Esta é a Sneffels.

A8: - A Sneffels?

L9: - Ela mesma, uma montanha alta de 5 mil pés, uma das mais admiradas do mundo, tanto que sua cratera chegou ao centro do globo.

A10: - Mas isto é impossível! Exclamei levantando os ombros e revoltado contra uma parecida suposição.

L11: - Impossivel! Respondeu o professor Lindenbrock num tom severo. E por que isso? 
A12: - Porque esta cratera está evidentemente obstruída pelas larvas, pelas rochas ardentes e então...

L13: - E esta não é uma cratera acabada?

A14: - Acabada?

L15: - Sim. O número de vulcões em atividade na superfície do globo são atualmente por volta de 300: mas existe uma maior quantidade de vulcões extintos. Logo a Sneffels se localiza entre estes últimos, e desde os tempos históricos ela teve uma erupção aquela de 1219; a partir desta época seus resíduos, se apagaram pouco a pouco, ela (cratera) não está mais entre os números de vulcões ativos.(...)

O fragmento apresentado mostra-nos claramente que Axel não tinha vontade de acompanhar seu tio em uma viagem louca. O diálogo estabelecido é uma sucessão de informações feitas ao professor, que não oferece respostas convincentes ao sobrinho, permitindo-lhe contra-argumentar facilmente. Todas as intervenções do sobrinho são tomadas em uma estratégia argumentativa.

A passagem mais nitidamente explicativa surge no turno (9), quando o tio fala da cratera do centro da Terra. Foi aí que Axel achou espaço para contra-argumentar. As falas de Lindenbrock até aqui apresentam informações simples sobre as quais era difícil reagir. Enfim, a afirmação do tio é bastante surpreendente para que Axel tente se opor. Percebemos, então, que argumentação e explicação estão misturadas.

A explicação, segundo a autora, surge quando há um problema de ordem cognitiva a resolver, e a fase de problematização sucede a fase de resolução do problema.

Segundo Jean-François Halté (1988 apud Leclaire -Halté, 1990:18),

o discurso explicativo é metacomunicacional, ou seja, temos um discurso primeiro que é interrompido pela emergência de um obstáculo cognitivo, e uma vez resolvido o problema, o discurso primeiro pode continuar.

O discurso explicativo (Genette,1972) tem a função de colocar em cena os saberes do mundo num dado momento em que ocorre ao mesmo tempo, uma narrativa primeira (informa os eventos da história) e uma segunda narrativa (remete aos personagens, aos eventos contidos na mesma história).

Como vemos, o estudo desta passagem do livro de Jules Verne abre diversas pistas para análise da articulação entre fala de personagens (na narração) e explicação. A primeira pista refere-se ao próprio enlaçamento explicativo, e pode ser associada às seguintes questões: a) qual fenômeno constitui obstáculo? (aqui, o obstáculo se refere à 
definição da cratera que o tio oferece ao sobrinho, o qual não aceita); b) pode-se indicar uma rápida tipologia dos objetos da explicação? (causa - a cratera chegou ao centro do globo; conseqüência - a cratera não está mais entre os vulcões ativos); c) como o obstáculo é manifestado, através das ações dos personagens, verbalmente ou de outra forma? (através das ações do sobrinho ao levantar os ombros de indignação e também verbalmente com as tentativas de explicações do tio); como o personagem explica? (por meio da solicitação do sobrinho, seu interlocutor); e) o que é que orienta a sua escolha? (as contra-argumentações do sobrinho); f) como retorna o primeiro discurso depois da explicação? (o professor continua explicando/narrando); g) como a explicação se articula ao diálogo? (a explicação aparece vinculada ao diálogo dos personagens).

A segunda pista parte das funções do discurso explicativo: h) na narrativa de ficção, os personagens explicam por explicar? (pelo menos aqui não, a explicação surge devido a um obstáculo que deve ser solucionado); i) quais seriam as diversas funções das explicações de personagens - informar, argumentar ou outra? (informar e argumentar); j) e em quais destas funções os personagens se inserem?(eles informam e argumentam). Enfim, as respostas a estas questões contribuem para evidenciar a estrutura narrativa.

Assim como ocorre a explicação nas narrativas de ficção, devido a um problema de ordem cognitiva a ser resolvido, de acordo com Leclaire-Halté, é possível também notarmos a presença desse fenômeno em outro tipo de narrativa (por exemplo: aquela produzida oralmente pela criança), pois a explicação, juntamente com a avaliação (Labov), parecem ser o cerne da produção de histórias e a razão principal para que estas se tornem significativas.

Com base neste pressuposto, nossa intenção é apresentar um exemplo de análise de narrativa, a partir do modelo laboviano (1972), mas procedendo de modo diferente do autor, uma vez que ele se ocupou de narrativas de experiências pessoais, "onde os locutores se preocupam em reconstruir, até em reviver, fatos de seu passado". Neste sentido, procuramos adaptar este modelo da narrativa (fundamentalmente a questão da avaliação) às histórias orais elaboradas por crianças de cinco anos. A função avaliativa diz respeito à necessidade que tem o locutor de manter o interesse do interlocutor durante a narração; a avaliação é um dos elementos estruturais da narrativa que tem por 
finalidade comunicar ao ouvinte o ponto de vista do narrador, em relação à história por ele narrada.

Partindo da idéia de que não há oposição fundamental entre explicação e narração, pois ao contar uma história explicamos e, ao explicar, legitimamos o caráter memorável daquilo que contamos; nosso interesse é aproximar a noção de avaliação, segundo Labov, do conceito de explicação, para verificarmos como os aspectos explicativo e narrativo se articulam nas histórias orais produzidas por crianças, ao mesmo tempo em que nos propomos identificar, também, o estatuto e o lugar que a “explicação" ocupa no interior das produções narrativas.

Na presente pesquisa, consideramos duas situações:

a) histórias orais produzidas a partir de desenhos feitos pelas crianças;

b) histórias orais elaboradas a partir das narrativas lidas em voz alta pela pesquisadora.

Diante das justificativas apresentadas e das duas circunstâncias expostas, levantamos as seguintes hipóteses, que procuraremos confirmar ao longo do presente trabalho:

1) o apoio visual pode auxiliar na construção de narrativas;

2) a compreensão de histórias parece preceder a sua produção;

3) a avaliação (Labov) pode ser o suporte para a produção das histórias.

Assim, se admitimos que a narrativa possa ser desenvolvida a partir de tais hipóteses, e que a sua qualidade pode depender das diferentes situações propostas, algumas questões passam a nos inquietar e o propósito, aqui, é somar esforços para tentarmos respondê-las.

1) É possível concluir que a qualidade narrativa da história produzida pela criança varia em relação à situação em que é solicitada a elaborar sua produção? 
2) Quais as relações entre produzir e compreender histórias? São habilidades relacionadas entre si ou independentes? Compreender histórias é mais fácil que produzilas?

3) O que sustenta a narrativa infantil - que elemento (s) o narrador utiliza para torná-la digna de ser narrada?

Considerando as questões levantadas, nosso propósito é realizar um estudo em torno da compreensão e produção de narrativas orais em crianças de cinco anos, de ambos os sexos, observando o papel e os efeitos da avaliação (Labov, 1972).

Para tanto, temos em vista três objetivos a serem atingidos em nosso estudo:

a) aproximar a noção de avaliação (Labov) do conceito de explicação para verificar como os aspectos narrativo e explicativo se articulam no interior das produções orais dos sujeitos;

b) evidenciar o valor argumentativo que o "contar" explicando adquire na construção dialógica;

c) observar até que ponto o desenho feito pela criança, e/ou as histórias lidas em voz alta pela pesquisadora, contribuem para aprimorar a qualidade narrativa da história. 


\section{CAPÍTULO 1 \\ EM TORNO DA NARRAÇÃO/NARRATIVA}

\subsection{As vias da narratologia}

Considerando a narrativa ser a mais nobre conquista da humanidade - a conquista do próprio homem - pois, conhecer, transmitir e comunicar a aventura de ser revela a busca constante do conhecimento do mundo e de si próprio, verificamos que a sua existência é imprescindível para o estudo do discurso oral, em que se cultivam valores essenciais para a formação do caráter do indivíduo e do pensamento coletivo. Através das histórias, o homem é capaz de sonhar, realizar desejos, construir conceitos para poder atribuir um sentido à vida.

Não podemos ignorar o poder da narrativa e sua importância em todas as culturas, que pela diversidade de suas formas e funções, às vezes, sagradas não podem ser estudadas dissociadas da experiência humana. Seu estudo tem sido ampliado desde o início do século XX pelas diversas disciplinas tradicionais - literatura, lingüística, antropologia, psicologia, sociologia, e constitui, hoje, um campo em sua totalidade: a narratologia.

De acordo com Laforest (1996), a variedade das abordagens narratológicas valoriza em parte duas concepções possíveis de seu objeto - a narração propriamente dita (os processos de elaboração do texto) e a narrativa (o texto elaborado). Estas duas concepções refletem a história recente das ciências humanas, desde o estruturalismo triunfante dos anos 70, o progresso paralelo da pragmática e dos seus diversos movimentos interacionistas, os quais postularam a necessidade de considerar o sujeito falante juntamente com o contexto de toda sua fala, incluindo o interesse que se dá atualmente à compreensão das operações cognitivas em jogo no uso da linguagem.

As duas concepções do objeto da narratologia derivam também em parte do tipo de narrativa à qual se associa. A partir desta perspectiva, é possível traçar uma linha de divisão entre a narrativa escrita (literária) e a narrativa oral, em que a primeira apaga a maior parte dos traços de sua elaboração, e uma vez finalizada atrai rapidamente a 
atenção do leitor sobre sua estrutura global; já a narrativa oral exibe as reformulações sucessivas nas quais ela se constrói temporalmente, e seduz a atenção do ouvinte para a dimensão processual da atividade narrativa.

Segundo Massini-Cagliari (1997), a escrita consiste numa representação da fala, e não uma transcrição dela. Assim, fala e escrita não se coincidem, mesmo sendo modalidades da mesma língua, uma vez que cada uma tem suas regras próprias de realização.

Enquanto a produção ortográfica anula a variação lingüística no nível fonético, a oralidade se ocupa dela. Mas essa não é a única diferença entre as modalidades, um exemplo disso é a afirmação tradicional de que - pelo fato da percepção da fala ocorrer por um canal auditivo e a da escrita por um canal visual - esta tem um caráter duradouro, pois pode ser arquivada pela sua própria natureza gráfica.

$\mathrm{Na}$ oralidade o interlocutor, em geral, tem que estar presente no momento da enunciação, enquanto que, na escrita ele pode se ausentar; e se presente, não precisa ser determinado, podendo ser apenas um interlocutor ideal, que o escritor tem em mente e a quem se dirige no momento da produção do texto.

$\mathrm{Na}$ escrita não ocorre o retorno imediato (feedback) como acontece na fala, em que o ouvinte se posiciona diante do falante, que pode corrigir ou acrescentar informações a seu texto em concordância ou discordância com as intervenções de seu interlocutor.

A presença do interlocutor no momento da oralidade e a inserção de falante e ouvinte em uma mesma situação comunicativa fazem com que a fala possa ser contextualizada pela própria situação de enunciação e pelas circunstâncias externas, presentes nessa situação. A escrita, ao contrário, geralmente tem de ser contextualizada no próprio discurso.

De acordo com Tannen (1982), a linguagem oral é altamente dependente de aspectos contextuais e a coesão é estabelecida através de recursos paralingüísticos e sinais não verbais. Já na escrita a coesão se dá por meio de recursos lexicais e estruturas sintáticas com conectivos explícitos.

Segundo Spinillo (1998), aprender a linguagem escrita requer mais do que uma simples aprendizagem de um código, e exige o domínio de recursos peculiares às formas de representação de palavras, por meio de sinais (escritura) na comunicação 
como: coesão, seqüência lógica, construções e convenções próprias das diversas manifestações gráficas. Assim, a linguagem escrita consiste em um sistema autônomo de um significado, e as noções que a criança tem sobre essa atividade se evidenciam através de suas produções. O domínio das convenções próprias dessa atividade implica em novas formas de processar a linguagem, envolvendo a elaboração de formas mais explícitas de comunicação.

\subsection{Algumas perspectivas teóricas sobre o texto narrativo}

A fim de esboçarmos uma linha cronológica de estudos sobre a estrutura do texto narrativo, começamos por Vladimir Propp ([1928]1970). Como se sabe, é dele o mérito de ter sido o primeiro a tentar formalizar a narrativa, ao extrair sua estrutura.

Propp analisou uma centena de contos maravilhosos russos tradicionais para classificá-los segundo sua estrutura, pois, de acordo com ele, a uniformidade específica do conto não se explica por temas, por motivos, por assuntos, ainda que eles se repitam, mas sim por unidades estruturais em torno das quais estes elementos se agrupam.

Partindo da análise das atitudes dos personagens, o autor percebe que há ações constantes, e as denomina de funções - estas funções ou ações constantes são independentes dos personagens que as praticam e do modo pelos quais são praticadas, isto é, as mesmas ações são realizadas por personagens diferentes e de várias maneiras. Ao término de sua análise, conclui que os contos maravilhosos são constituídos de uma seqüência de 31 funções constantes, ligadas umas às outras por uma relação de implicação, cuja sucessão, no conto, é sempre idêntica. É possível que um conto não apresente todas as funções, mas é impossível que a ordem das funções no conto seja modificada.

Segundo Propp, as 31 funções se dividem em três momentos: seção preparatória (introdução de alguns personagens); primeira seqüência (desenrolar das ações); e segunda seqüência (desfecho das ações).

Embora o folclorista russo insista em afirmar ter sido seu objetivo primordial estudar as funções e não os personagens dos contos maravilhosos, percebemos que ao conceituar função, ele acabou por formular, implicitamente, um conceito de personagem. Assim, além das 31 funções no conto, Propp também define sete 
personagens, tendo cada um sua esfera de ação: o Herói, a Princesa (objeto de busca do herói), o Agressor, o Mandante (que envia o herói em missão), o Doador (que submete o herói a uma primeira prova e o recompensa dando-lhe um Auxiliar), o Auxiliar e o Impostor ao falso herói. A lista das funções e dos personagens de Propp se detém no meio caminho entre a manifestação de superfície concreta do conto ocorrência e a estrutura profunda abstrata do relato arquetípico. $\mathrm{O}$ autor ainda utiliza critérios semânticos para continuar sua análise, estabelecendo uma classificação no interior de cada função, baseada na natureza dos elementos que a preenchem.

Porém, as esferas de ação construídas por Propp não podem ser adaptadas a qualquer narrativa, tendo em vista seu procedimento metodológico e os conceitos por ele formulados a partir da análise dos contos maravilhosos russos.

Nesta perspectiva, Greimas (1964), objetivando ampliar a dimensão genérica dos personagens proppianos para chegar ao estabelecimento de uma matriz actancial passível de ser aplicada a qualquer texto narrativo, propõe que os personagens sejam denominados de actantes (atores), termo utilizado para os seres ficcionais que aparecem sob diferentes roupagens, em cada narrativa particular.

Fundamentando-se nas lições de Propp sobre o personagem no teatro e as observações acerca da funcionalidade das palavras no discurso lingüístico, o autor define três categorias actanciais - 1) Sujeito $x$ Objeto; 2) Remetente $x$ Destinatário; 3 ) Ajudante $x$ Opositor - que, ao mesmo tempo em que tentam fugir da peculiaridade das teorias nas quais se inspiram, buscam explicitar as relações que se estabeleceriam entre os seis actantes, apontando-os como comuns a qualquer narrativa:

Remetente Objeto Destinatário

\section{$\uparrow$}

Ajudante Sujeito Opositor

As relações que esses seis actantes mantêm uns com os outros correspondem às modalidades fundamentais da atividade humana: querer (o sujeito deseja o objeto), 
saber (o remetente destina o objeto ao destinatário), poder (o sujeito, contrariado pelo opositor, é auxiliado pelo ajudante); estabelecendo assim, um esquema narrativo geral, o da busca ou procura, e três tipos de elementos narrativos fundamentais: "desempenho" (as provas), "contrato" (estabelecimento de um pacto, execução ou ruptura desse pacto, recompensa ou castigo) e por fim os "disjuntivos" (partidas, separações) / "conjuntivos" (retornos, reuniões).

Como observamos, essa estrutura arquetípica do conto contribui sem dúvida para a sua ficticidade. O ouvinte ou leitor compreende logo de início que esse tipo de relato não procura reproduzir fielmente uma experiência, mas sim se conformar com uma classe de relatos.

Visando ainda ressaltar a estrutura do texto narrativo, é válido mencionar, também, mais dois autores que se dedicaram a esse campo de estudo: Bremond e Todorov.

Claude Bremond (1966) a partir de Propp observa que até então, os estudiosos da narrativa concentrando seus esforços na codificação das seqüências de eventos reais, em que o encadeamento constitui a face material da história, não levaram em conta os modos dos verbos, ou seja, interessavam-se pelas ações narrativas efetivamente realizadas, não se importando com as ações em potencial, as quais podem ou não vir a ser concretizadas. A partir dessa perspectiva, o autor traça regras gerais para o desenvolvimento de toda a narrativa, operando a partir de uma matriz inicial de três seqüências: uma que abre a possibilidade do processo (degradação-melhoria), uma que realiza tal possibilidade (mérito-recompensa), e uma que conclui o processo com sucesso ou fracasso (demérito-castigo).

Essa matriz hierarquizada nem sempre é realizada integralmente em cada conto, sendo a seqüência degradação-melhoria necessária e as outras facultativas.

Apoiando-se em Bremond, Todorov (1971), na tentativa de construir uma gramática narrativa, estudando os cem contos que compõem o II Decameron de Boccacio, chama a nossa atenção para os aspectos modais que podem envolver as ações dos personagens. 
A teoria dos modos que Todorov propõe fornece um instrumento de análise das ações virtuais que, juntamente com aquelas plenamente realizadas, constitui o universo da intriga.

Dessa forma, o autor distingue cinco modos de ação - um, o indicativo, o modo das ações realmente realizadas e outros quatro ele reúne em dois grupos:

1) os modos da vontade - a este grupo pertencem - o modo obrigatório, as ações devem ser realizadas, em obediência às exigências ditadas pela vontade coletiva ou por uma lei social; e o modo optativo - das ações que só se realizam por força de um imperativo individual, independentemente de qualquer coerção grupal;

2) os modos da hipótese - a este grupo pertencem o modo condicional estabelecimento de uma relação implicativa entre duas ações, de maneira que o responsável pela condição imposta e por sua conseqüência seja um só e mesmo personagem; e o modo preditivo, ao contrário, só ocorre quando o personagem que faz a predição nada tem a ver com a conseqüência prevista.

Para visualizarmos, de maneira global, a evolução da estrutura narrativa, apresentamos, de forma sintética, o conceito de organização de história proposto pelos autores citados no quadro que segue. 
Quadro 1 - As estruturas narrativas propostas por Propp, Greimas, Bremond e Todorov

\begin{tabular}{|c|c|c|c|}
\hline AUTORES & \multicolumn{3}{|c|}{ ESTRUTURA NARRATIVA } \\
\hline & Introdução & Desenvolvimento & Finalização \\
\hline Propp (1928) & $\begin{array}{l}\text { Seção preparatória: } \\
\text { introdução de } \\
\text { personagens }\end{array}$ & $\begin{array}{l}\text { Primeira seqüência: } \\
\text { desenrolar das ações }\end{array}$ & $\begin{array}{l}\text { Segunda seqüência: } \\
\text { desfecho das ações }\end{array}$ \\
\hline Greimas (1964) & $\begin{array}{l}\text { Desempenho (as } \\
\text { provas) }\end{array}$ & $\begin{array}{l}\text { Contrato } \\
\text { (estabelecimento de } \\
\text { um pacto, execução } \\
\text { ou ruptura desse } \\
\text { pacto, recompensa ou } \\
\text { castigo) }\end{array}$ & $\begin{array}{l}\begin{array}{l}\text { Disjuntivos } \\
\text { (partidas }\end{array} \\
\text { separações); } \\
\text { Conjuntivos } \\
\text { (retornos } \\
\text { reuniões) }\end{array}$ \\
\hline Bremond (1966) & $\begin{array}{l}\text { Degradação/ } \\
\text { Melhoria }\end{array}$ & Mérito/Recompensa & Sucesso/ Fracasso \\
\hline Todorov (1971) & $\begin{array}{l}\text { Indicativo: ações } \\
\text { realizadas }\end{array}$ & $\begin{array}{l}\text { Modos de vontade: } \\
\text { modo obrigatório } \\
\text { (ações devem ser } \\
\text { realizadas); modo } \\
\text { optativo } \\
\begin{array}{l}\text { podem ou não scoes } \\
\text { realizadas) }\end{array}\end{array}$ & $\begin{array}{l}\text { Modos da hipótese: } \\
\text { modo condicional } \\
\text { (o personagem } \\
\text { determina } \\
\text { condição, sendo } \\
\text { responsável } \\
\text { ela); } \\
\text { preditivo } \\
\text { personagem } \\
\text { prediz, nada tem a } \\
\text { ver com } \\
\text { seqüência prevista) }\end{array}$ \\
\hline
\end{tabular}


Labov (1972), ao contrário destes estudiosos (que se dedicaram às narrativas literárias), é destacado como um dos primeiros a se interessar pela narrativa oral (isto é, a narrativa conversacional e não o conto oral).

Em relação aos modelos elaborados pelos semioticistas ou gramáticos, que parecem, às vezes, mais preocupados em esclarecer a estrutura profunda do texto, tal como se pode desenvolvê-la ou deduzi-la, o modelo laboviano considera a superfície do texto, da narração plenamente desenvolvida, tal como ela é ouvida pelo alocutário da conversa.

A observação de um corpus homogêneo de narrativas de experiência de perigo/risco de morte leva o autor a concluir que a narração completa apresenta seis elementos recorrentes ou partes da narração:

1. resumo - uma ou duas proposições que sintetizam toda a história;

2. orientação: quem? quando? o quê? onde? - elementos que situam os personagens, o lugar e o momento da história;

3. complicação: e depois? o que se passou? - seqüências dos acontecimentos e ações que formam o corpo da narração;

4. avaliação: por quê? - o narrador informa a carga dramática ou clima emocional;

5. resolução (ou resultado) - como isso terminou?

6. coda - o narrador informa que sua narrativa acabou.

Se o estruturalismo originário de Propp privilegia a ênfase numa estrutura narrativa repetitiva, Labov, ao contrário, enfatiza a narrativa como discurso, e a avaliação como aquilo que torna o texto digno de ser contado.

Sob esta ótica, o autor considera a narrativa como uma técnica de construção de unidades, as quais recapitulam a experiência na mesma ordem dos eventos originais e mostram que a seqüência temporal é sua prioridade definidora. Ele também ressalta que 
para existir a narrativa é indispensável o acontecimento singular e inédito, digno de ser narrado.

Nesta perspectiva, analisamos o papel da avaliação na narrativa de acordo com o modelo referido, mas procedendo de maneira diferente do autor, pois ele organizou a estrutura da narrativa a partir de relatos de experiências pessoais (como mencionado na introdução). Assim, adaptamos o modelo laboviano de narrativa oral às histórias produzidas pelas crianças.

De acordo com Melo (2000), a avaliação consiste na atitude do narrador frente à sua narrativa, transmitindo seu ponto de vista e sentimentos, chamando a atenção do interlocutor para aquilo que está narrando, a sua história. Verificamos esse conceito nas próprias palavras do autor:

os procedimentos que o narrador emprega para indicar o propósito de sua história, sua razão de ser: porque ele conta, aonde quer chegar. Porque há muitos modos de contar a mesma história, e podemos fazê-lo dizer coisas muito diferentes, ou nada. (Labov,1972:302)

Quando uma narrativa apresenta a avaliação, o interlocutor se prende mais à sua história, pois o narrador utiliza certos mecanismos que vão identificar a subjetividade e o seu posicionamento diante do fato narrado.

Porém, quando uma narrativa não apresenta esta função, podemos dizer que o interlocutor não se sente interessado nela, pois o narrador não conseguiu chamar a atenção dele para o conflito da história. Há, portanto, um conflito que vai sendo complicado, há a resolução desse conflito e assim termina a narração, sem que haja alguma manifestação mais subjetiva. A narrativa, então, fica "pobre”, parecendo faltar alguns detalhes.

Labov distingue quatro tipos de avaliação: avaliação externa, avaliação encaixada, ação avaliativa e avaliação por suspensão da ação. Aqui levamos em conta os três primeiros tipos, observando que (segundo Labov) "quase todos os procedimentos de avaliação têm como fim suspender a ação". 
a) Avaliação externa: o narrador interrompe a narrativa, vira-se para o ouvinte e lhe comunica qual é o seu ponto de vista sobre o fato narrado, ocorre à suspensão da ação (ato de narrar). Vejamos o exemplo:

M: (...) e ai os três patinhos... que não eram bobos...

b) Avaliação encaixada: ela se encontra no próprio desenvolvimento da narrativa, prescindindo desta maneira de sua continuidade dramática, corresponde à utilização dos discursos reportados diretos (sobretudo) ou indiretos, marcados ou não na narrativa. $\mathrm{O}$ discurso reportado é, ao mesmo tempo, um mecanismo de avaliação da narrativa e um meio utilizado para alcançar a adesão do ouvinte:

M: (...) ela ela pega ela bate na porta

M: (...) é um era bem velhinho tinha um que era MAIS velho ... e o dente já tava mole

Y: (...) a mãe não viu porque estava nas compras

c) Ação avaliativa: o narrador descreve o que os personagens fizeram, em vez de relatar o que disseram. Do mesmo modo, neste caso, o locutor se revela capaz de encaixar seu comentário inesperado:

M: ela ela abriu uma portinha caiu na maravilha viu um monte de borboleta e umas flores gravada com um sol BEM Longe... uma flor ela cheirou ... a outra arrancou e uma veio um tomate

Após abordar a estrutura da narrativa e principalmente a avaliação, Labov também fala sobre o enriquecimento da sintaxe narrativa que se baseia em tudo o que na narrativa não é do fato narrado. Trata-se de diferentes organizadores que podem ser expressos graças a meios lingüísticos simples, ou de processos de avaliação que permitem ao locutor assinalar o interesse do que ele narra. Neste sentido, Labov propõe quatro instrumentos principais (ou elementos avaliativos), conforme os procedimentos sintáticos utilizados: (1) intensificadores; (2) comparadores; (3) correlativos e (4) explicativos. 
1. Intensificadores - fonologia expressiva, repetições, quantificadores, itens lexicais:

a) fonologia expressiva - alongamentos e entonação de voz ocorridos na oralidade:

“... eu falei AI MEU DEUS do céu"

“... o carro começou a rodar assim ... $\tilde{A} \tilde{A} \tilde{A}$ meu Deus ...”

b) repetições - na oralidade elas ocorrem com bastante freqüência e, por isso, conseguem intensificar a ação:

“... ai nós corremos corREmos corRemos ... o Yannick até emagreceu né ...”

c) quantificadores - advérbios de intensidade, palavras que indicam grande quantidade:

“... ela ficou toda roxa..."

“... conversou com meio mundo...”

d) itens lexicais - palavras que estão em outra função narrativa, mas que desempenham papel avaliativo:

“... eles me disseram que hoje era o grande dia ..."

2. Comparadores: "é tudo aquilo que se relaciona à situação atual com outra coisa" (François, 1996:174). E estes são subdivididos em:

e) imperativos - a escolha desse modo verbal intensifica o comando em uma narrativa:

“... VAMOS FICAR QUIETOS? VOCÊS DOIS AP’

f) perguntas - esses elementos valorizam o suspense que o narrador pretende oferecer ao conflito:

“... dai ele pensou UM O QUÊ um gatinho um cachorrinho que que pode ser né?...” 
g) negação com valor expressivo ou comparativo - a negação é chamada de comparativa (Labov) quando ela permite avaliar os acontecimentos constatados, opondo-os a todos aqueles que poderiam ocorrer.

“... não estava tão preocupada $N E ́ . . . ”$

h) futuros - o futuro do pretérito compara a ação que ocorreu com aquela que deixou de acontecer, enfatizando o momento imaginado.

“... porque caso contrário ele podia até morrer...”

3. Correlativos - "um correlator serve para aproximar dois fatos que realmente aconteceram e se encontram ainda reunidos em uma mesma oração independente". (Labov, op.cit.:326). Ou seja, ele serve para associar os diferentes aspectos da oralidade:

“... minha mãe fala eu não posso falál quando como ela falô/ eu não posso falar ela tomou meu prato”

4. Explicativos - trata-se de orações subordinadas que trazem explicações ou avaliações, às quais estão ligadas:

“... a mãe não viu porque estava nas compras”

Até aqui acreditamos ter mostrado os procedimentos de avaliação, segundo Labov, através dos quais o locutor pode atrair o interesse do interlocutor em relação ao que narra.

Mas o que é uma narrativa?

Diante da diversidade de abordagens narratológicas, uma definição consensual, precisa e definitiva da narrativa pode ser elaborada? Um ponto sobre o qual todos os pesquisadores são unânimes é sobre a dificuldade de formular uma definição satisfatória. Para Gülich e Quasthoff (1985 apud Laforest, 1996:17), esta dificuldade 
nem sempre resolvida, coloca em questão a própria existência da narratologia enquanto estudo transdisciplinar da narrativa.

De acordo com Laforest (1996:17-19), os critérios de definição de narrativa mais freqüentes de evocação são os seguintes (Güilich et Quasthoff, 1985; Fayol, 1985):

1. Anterioridade dos acontecimentos relatados em relação ao tempo da enunciação. Este critério é essencial, embora não suficiente, permite distinguir a narração da descrição.

2. Organização em torno de um acontecimento único, em um momento, em um lugar particular. É possível opor à narração da enumeração de acontecimentos passados; entretanto, é válido para a narração conversacional, como também para as narrativas escritas curtas. Não é válido para a narrativa de vida ou narrativa literária longa.

3. Os acontecimentos e as ações relatados conduzem a uma transformação ou a uma mudança. Este critério de mudança entre estado inicial e final é determinante para os semioticistas estruturalistas. Mas, a experiência de Laforest com narrativas orais, leva a crer que o contexto, ou o conjunto de uma conversação podem, eventualmente, permitir interpretar como narração uma seqüência de ações que não obedece à esse critério.

4. Os acontecimentos relatados são ligados por uma relação de causa/efeito (no sentido amplo). Este critério, indiretamente ligado ao precedente, exige marcas semelhantes.

5. Presença de um protagonista geralmente humano ou agindo como tal (é o caso das fábulas, por exemplo). Na narração oral, o narrador é geralmente o herói, ou pelo menos um dos protagonistas. Além disso, o fato de o narrador ser ator ou menos testemunha direta de acontecimentos, permite distinguir a narração do relato (de um filme ou de uma notícia policial).

6. A narração deve conter pelo menos um elemento inesperado, oriundo do ordinário rememorável, que assegura o "contar" (Labov, 1972). Trata-se, mais uma vez, de um critério útil ao oral do que ao escrito, pelo menos se entendemos por "elemento" um acontecimento e não uma maneira de contá-lo. O "fora do ordinário" se avalia em 
relação às normas vigentes em uma dada cultura e às expectativas dos participantes da interação.

7. Presença de certa tensão, de uma dramatização dos acontecimentos; as recapitulações da experiência vivida que não apresentam este traço são consideradas anedotas e não narrativas.

8. No plano formal, surgem os seguintes traços: tempos verbais particulares imperfeito, pretérito perfeito e presente histórico; e o discurso direto.

Com base nos estudos mencionados, percebemos a existência de uma formulação vaga da aplicabilidade desses critérios a um grande número de narrativas. Todo esforço de precisão tem como efeito reduzir o número das variedades narrativas às quais os critérios se aplicam.

Segundo Guimarães (1995), a simultaneidade, a anterioridade ou a posterioridade da narrativa, podem ser apresentadas por elementos lingüísticos - os dêiticos - que mostram a presença do emissor no enunciado, o qual realiza uma situação definida pelas coordenadas espacial-temporais. São considerados dêiticos os pronomes demonstrativos, certas locuções prepositivas/adverbiais e os advérbios de tempo. Os pronomes pessoais e as desinências verbais indicam os participantes do ato do discurso.

Ainda de acordo com a autora, a organização estrutural clássica da narrativa corresponde à seqüência dos fatos alinhados em direção a um desfecho previsível em relação à linha seqüencial da história.

Apoiando-se na perspectiva de Van Dijk (1983), Guimarães (op.cit.:66) sugere três categorias fundamentais: exposição (apresentação do espaço, do tempo e do ambiente), complicação (relato dos acontecimentos) e resolução (desfecho) que tecem o esquema canônico da narrativa. No entanto, o autor considera que uma avaliação e uma moral (reflexões finais do narrador) podem eventualmente completar o esquema narrativo. Aqui, observamos que este esquema (baseado em Van Dijk) difere do modelo de narrativa oral proposto por Labov (1972), que considera a avaliação um dos elementos essenciais para a existência da narrativa, como já foi discutido. 
Em Bruner (1997), verificamos que a propriedade fundamental da narrativa é a seqüencialidade. Examinando como a narrativa organiza a experiência humana e utilizando como exemplo a memória, ele explica o processo de "produção de significado".

O autor considera a narrativa e o modo como é construída (em torno de expectativas canônicas) a essência para a formação da "psicologia popular" - sistema em que as pessoas organizam suas experiências no mundo social (trata de agentes humanos que fazem coisas com base em suas crenças e desejos empenhando-se no atendimento a metas).

Observando que as narrativas são elaboradas apenas quando são violadas crenças constituintes de uma psicologia popular, ele menciona sobre o estatuto canônico desta psicologia: sintetizando não apenas como as coisas são, mas (implicitamente) como elas deveriam ser. Quando as coisas "são como deveriam ser", as narrativas da psicologia popular são desnecessárias.

A narrativa também forja ligações entre o excepcional e o comum. Este se refere aquilo que as pessoas aceitam e subentendem sobre o comportamento. Em contraste ao excepcional (encontrar uma exceção ao comum) faz com que se crie uma história para justificar tal fato. Dessa forma, a narrativa é um relato do mundo possível para atribuir sentido a exceção encontrada.

Nesta perspectiva a função da história é: "encontrar um estado intencional que atenue ou pelo menos torne compreensível um afastamento de um padrão canônico" (Bruner, op.cit.:50).

O autor constata ainda a "paisagem dual da narrativa", os eventos e ações em um mundo real, que supomos verdadeiros ocorrem concomitantemente com eventos mentais na consciência do protagonista, ou seja, a abordagem da realidade $\mathrm{x}$ imaginação.

Como vemos, a narrativa é um veículo natural para a psicologia popular, pois ela é assimilada juntamente com as ações e intenções humanas, em que se misturam os mundos canônicos da cultura, dos desejos, das crenças e das esperanças, tornando o excepcional compreensível, mantendo afastado o que é estranho, salvo quando este se faz necessário. Desse modo, a narrativa tem o poder de ensinar, conservar a memória, ou alterar o passado. 
A fim de identificar as peculiaridades entre a narrativa ficcional e empírica (experiências vividas), Bruner (op.cit.:53) levanta duas hipóteses: a primeira se refere à facilidade de nos identificarmos com as histórias subjuntivas, pois podemos experimentá-las em uma dimensão psicológica, sendo aceitas, quando se encaixam com os compromissos estabelecidos e rejeitadas quando se furtam de uma identificação. A história é uma experiência vicária, que inclui relatos de experiências reais ou a imaginação culturalmente modelada. A segunda hipótese é que uma história é sempre história de alguém viável à negociação social.

A aquisição da habilidade de narrar é uma conquista da prática social que oferece estabilidade à criança pequena para ir à busca do significado.

Uma vez que a criança capta a idéia básica da referência necessária para qualquer uso da linguagem, seu principal interesse lingüístico passa a centrar-se na ação humana e em seus resultados. Ela mostra-se desde cedo sensível às metas e a sua aquisição, adquirindo variantes de expressão como "foi embora" para conclusão, e "uh oh", para não conclusão, esta é a primeira exigência da narrativa. Uma segunda exigência se refere à manutenção padronizada de uma seqüência; a criança domina muito cedo as formas gramaticais e lexicais para unir as seqüências que elas relatam, e pelo uso de temporais como "então" e "depois". A terceira exigência da narrativa trata do ponto de vista do falante, na criança muito pequena ele pode ser caracterizado pelo choro (prosódia).

Estas três características de construção: variantes de expressão; formas gramaticais e lexicais; e prosódicas, mencionadas acima, fornecem à criança um arsenal de ferramentas para aquisição de narrativas.

Dessa maneira, o autor explora as origens da aptidão de narrar na cultura humana, indicando como os jovens, por dom inato e exposição ao meio, participam na sociedade utilizando a linguagem e seu discurso narrativo in vivo. Por meio de tais observações, ele supõe que a estrutura da gramática humana poderia ter surgido de um impulso protolingüístico para a narrativa. 


\subsection{O contar no contexto da Psicanálise}

Partindo agora para uma vertente diferente, abordamos neste tópico, de forma não expansiva, o funcionamento do aparelho psíquico proposto por Freud (1987) e Lacan (1993), os conceitos de inconsciente e linguagem para estabelecermos uma relação entre eles (inconsciente e linguagem), as narrativas e o espaço potencial (lugar psíquico onde é possível, por meio do brincar, criar histórias).

De acordo com Freud (1987), a mente humana é dividida em dois sistemas: o pré-consciente/consciência (Pcs/Cs) e o inconsciente (Ics). No inconsciente estão as representações de coisas, uma espécie de arquivo visual, e estes conteúdos só se tornarão conscientes quando se ligarem às representações de palavras que lhe correspondam.

O psiquismo, segundo Freud, é regulado por três princípios: princípio da constância (busca manter sempre constante, ou reduzido ao máximo, a tensão do aparelho psíquico); princípio do prazer (evita o desprazer e proporciona o prazer); e o princípio da realidade (tenta modificar o princípio do prazer, à medida que o psiquismo vai evoluindo). Há também modelos teóricos fíctícios destinados a explicar a complexidade do funcionamento do aparelho psíquico, as instâncias psíquicas: ID (representa o pólo pulsional, inconsciente, funcionando segundo o princípio do prazer, procurando apenas satisfação imediata); Ego (regido pelo princípio da realidade) e o Superego (se opõe ao ego, informando quando os desejos são impróprios, agindo como instância formadora da moral).

Visto que em Psicanálise o percurso dos eventos mentais é regulado pelo princípio de prazer e de realidade, podemos pensar que o contar e ouvir histórias também são movidos pelos mesmos princípios, que satisfazem o desejo humano: a busca do "self".

Freud, analisando o inconsciente reflete sobre os mecanismos de lembrança e de esquecimento, questões fundamentais para a narrativa, e percebe que ambos os processos obedecem aos mesmos mecanismos da condensação e do deslocamento no funcionamento da linguagem. A condensação (lembrança) ocorre quando um elemento é conservado na memória, apenas porque está presente por diversas vezes em diferentes pensamentos do sonho, e a mistura de imagens pode chegar a atenuar traços que não 
coincidem para manter e reforçar apenas traços comuns; e o deslocamento (esquecimento) diz respeito a uma representação majoritária (um elemento conservado na memória) que se desloca para o inconsciente.

Observando que o inconsciente é estruturado de acordo com os mecanismos do esquecimento e da lembrança, Lacan seguindo Jakobson, aproximou estas duas noções às figuras lingüísticas da metáfora e da metonímia, para em seguida afirmar que: "o inconsciente é estruturado como uma linguagem". (Lacan, 1993:45).

Neste sentido, ele sintetiza o aparelho psíquico numa estrutura única composta pelo Real e pelos registros do Imaginário e do Simbólico, e apresenta um objeto apto a reunir seus preceitos, construídos por três círculos, entrelaçados e inseparáveis.

Dessa forma, a concatenação dos registros e suas lógicas recíprocas evitam que os três círculos sejam considerados separadamente, pois funcionam em uníssono; mesmo cada um tendo seu status, nenhum deles tem mais ou menos hierarquia que os outros e atuam de maneira conjunta.

Como vemos, o Real é simultaneamente condição para o Simbólico e o que o excede, o que sobra do processo de simbolização, é o impossível de ser simbolizado totalmente na oralidade ou na escrita; o Simbólico está ligado à língua e mais especificamente, ao significante, diz respeito a toda e qualquer atividade humana, fazendo do homem um animal regido pela linguagem; e o Imaginário constitui-se através do Simbólico, prevalecendo a relação com a imagem do semelhante.

Estes registros lacanianos que constituem o indivíduo (Real, Simbólico e Imaginário), associando-os às histórias, nos levam a crer que a linguagem simbólica das narrativas favorece a elaboração mental da relação do real com o imaginário, aproximando prazerosamente as crianças da realidade consistente, conduzindo-as paulatinamente a uma progressiva maturidade.

De acordo com Saleh (2000), é pela representação, aquela que se dá no nível do Imaginário, que o sujeito se relaciona com a linguagem das histórias, pois não é possível o acesso direto ao Real que apenas é perceptível no nível do Simbólico.

Retornando a Propp (1997), a unidade de composição do conto reside na sua realidade histórica; assim as histórias assumem a função de transmitir os valores humanos através da fantasia. E, visto que o espaço potencial, segundo Winnicott (1975), é o lugar onde a realidade pode ser enriquecida com a imaginação, através da 
simbolização do processo criativo, então a experiência cultural se manifesta neste espaço por meio do "brincar", contar histórias, uma forma de jogo que pertence à cultura.

Hisada (1998) considera o espaço potencial uma zona intermediária entre a realidade interna e externa, lugar onde se realiza o jogo, a brincadeira, origem de todas as atividades sócio-culturais. E o passaporte para entrar nessa área é a capacidade de poder brincar e imaginar, pois é através da magia que se permite entrar nesse mundo de sonhos, de criação e de prazer.

Com as histórias infantis pode-se aprender mais sobre os problemas interiores dos seres humanos, como proceder corretamente para solucioná-los. É característica dessas narrativas colocar um dilema existencial de forma breve e categórica, e isso permite à criança apreender o problema na sua totalidade. Como toda obra de arte, as narrativas tanto agradam quanto instruem, sua genialidade especial é que elas falam diretamente à criança, precisamente na idade em que essas histórias são mais significativas para ela, dado seu intenso processo de amadurecimento para articular seu mundo interior e exterior.

Desse modo, as narrativas traduzem bem a imaginação, o prazer, o encantamento, elementos essenciais para o crescimento, estruturação da criatividade e do raciocínio lógico. E a criança pode desenvolver a criatividade, o potencial crítico por meio da reflexão e do questionamento dos comportamentos e ações dos personagens.

Freud também enxerga nos contos uma forma atenuada dos mitos, considera que estes são "remanescentes deformados de fantasias de desejo de nações inteiras, os sonhos seculares da jovem humanidade".

Ainda de acordo com o autor, os contos que procedem sinteticamente, por imagens, parecem, às vezes, muito próximos das fantasias reveladas pela Psicanálise, assim como os mitos, os contos também constituíram materiais privilegiados para essa linha de estudo da mente humana, pois é através do folclore, da arte e do sonho que os freudianos ilustram suas teorias para a formação de uma abordagem teórica, centrada no estudo do psiquismo humano. 


\subsection{A função semiótica ou simbólica na criança}

Rector e Trinta (1993), apoiando-se em Peirce (1977), argumentam que a semiótica é uma teoria da significação, que analisa e explica os mecanismos pelos quais um signo - representação de objeto, idéia ou coisa - sugere determinado significado para alguém, proporcionando o aparecimento de um outro signo.

De acordo com Piaget e Inhelder (1995), essa função semiótica que consiste em poder representar alguma coisa, por meio de um significante diferenciado/signo linguagem, imagem mental, gesto simbólico entre outros -, surge ao término do período sensório-motor (11/2 e 2 anos).

Assim, antes do segundo ano de vida da criança (Piaget, 1995), não há ainda representação, mas temos a constituição e utilização de significações, pois toda assimilação (percepção) sensório-motora já confere significações.

No decorrer dos dois anos de idade, surge um conjunto de condutas que supõe a evocação representativa de um objeto ou de um acontecimento ausente, que envolve a construção de significantes diferenciados/signos. A seguir, destacaremos algumas destas condutas de aparecimento mais ou menos simultâneas: 1) a imitação diferida - surge na ausência do modelo (inicialmente a criança começa imitando na presença do modelo, e depois continua a fazê-lo na ausência deste); 2) jogo simbólico - a criança pode fingir estar dormindo (aqui a representação é nítida e o significante diferenciado/signo é um gesto imitativo), esta conduta é desconhecida no nível sensório-motor; 3) desenho - é intermediário entre o jogo e a imagem mental; 4) imagem mental - surge como imitação interiorizada; 5) linguagem - permite a evocação verbal de elementos não atuais.

A imitação constitui no decurso do período sensório-motor (11/2 e 2 anos) uma espécie de representação em atos materiais e não em pensamentos, ainda. Ao término deste nível, surge a imitação diferida - $\mathrm{o}$ ato desligado do contexto torna-se significante diferenciado/signo, possibilitando em parte a representação em pensamento. Com a imagem mental, a imitação passa a ser interiorizada e a representação, que ela possibilita, é dissociada do ato exterior. 


\section{O jogo simbólico}

Segundo Vygotsky (1989), toda criança no seu processo de desenvolvimento "brinca" para preencher suas necessidades, e para tanto utiliza o brinquedo. Entendemos, aqui, por brinquedo um mundo imaginário onde os desejos não realizáveis podem ser realizados.

A tendência de uma criança muito pequena é satisfazer seus desejos imediatamente, mas na idade pré-escolar (5anos) surge uma grande quantidade de tendências e desejos não realizáveis imediatamente, e para resolver essa tensão a criança envolve-se neste mundo imaginário de representações.

Vários pesquisadores que tratam desse assunto concluíram que o brinquedo envolvendo uma situação imaginária é um brinquedo baseado em regras. Assim, a criança que está representando o papel da mãe, obedece às regras de comportamento maternal. Da mesma forma que uma situação imaginária tem que conter regras de comportamento, todo jogo com regras contém uma situação imaginária.

O comportamento de uma criança muito pequena é limitado em todas as ações pela restrição situacional, os objetos têm uma força motivadora inerente nessas ações e determinam o comportamento da criança, pois nessa idade a percepção é um aspecto integrado de uma reação motora.

A ação numa situação imaginária ensina a criança a dirigir seu comportamento pelo significado dessa situação, é impossível para uma criança muito pequena separar o campo do significado do campo da percepção visual, já que há uma fusão entre o significado e o que é visto.

Já na idade pré-escolar ocorre uma divergência entre os campos do significado e da visão. No brinquedo (mundo da imaginação) o pensamento está separado dos objetos e a ação surge das idéias e não das coisas - a criança não consegue ainda separar o pensamento do objeto real, para imaginar um cavalo ela precisa definir sua ação usando, por exemplo, um "cavalo-de-pau” como pivô.

$\mathrm{Na}$ situação imaginária, a criança opera com significados desligados dos objetos e ações aos quais estão habitualmente vinculados, mas ela também inclui ações e objetos reais; espontaneamente a criança usa sua capacidade de separar significado do objeto sem 
saber que o está fazendo, assim ela atinge uma definição funcional de conceitos ou de objetos, e as palavras passam a se tornar parte de algo concreto.

No início do desenvolvimento a ação predomina sobre o significado. Na idade pré-escolar o significado passa a ser determinante. A criança quer e realiza seus desejos permitindo que as categorias básicas da realidade passem através de sua experiência. Se operar com o significado de coisas leva ao pensamento abstrato, observa-se que o desenvolvimento da vontade, a capacidade de fazer escolhas, ocorre quando ela opera com o significado de ações.

Segundo o autor, esse mundo imaginário - o brinquedo - não é só um aspecto predominante da infância, mas é um fator importante do desenvolvimento, pois ele fornece ampla estrutura básica para mudanças das necessidades e da consciência - a ação na esfera imaginativa, a criação das intenções voluntárias e a formação dos planos na vida real.

De acordo com Gardner (1994), durante os primeiros anos de vida, por meio de seqüências simbólicas ou brincadeiras de faz-de-conta, a criança brinca sozinha, com bonecos de seu tamanho, com companheiros ou pais. Ela é capaz de representar festas de faz-de-conta, sozinha ou com amigos, e de recriar partes destes eventos em seus desenhos, em sonhos diurnos ou noturnos.

Em muitas sociedades os jogos simbólicos constituem uma forma primária de uso dos símbolos para criança pequena, onde ela tem uma oportunidade de experimentar papéis e comportamentos que irão, posteriormente, assumir no mundo adulto ou em conjunto com crianças maiores.

A partir de tais constatações, o autor, presume que a criança já possui uma "linguagem do pensamento", algum tipo de idéia mental, onde ela representa para si mesma fatos sobre o mundo (ex: aquilo é uma cadeira, este cachorro está perto). É claro que ela não usa tais simbolizações explicitamente, mas o seu conhecimento de mundo pressupõe algum tipo de meio para representar o input de seus sentidos, como um tipo de linguagem interna que atua sobre tais representações.

Quando uma criança engaja-se no faz-de-conta, ela se envolve em um tipo de atividade mental diferente da representação de "primeira ordem" correta. Nesta representação (primeira ordem), quando a criança vê uma banana, ela rotula para si mesma, "isto é uma banana". E posteriormente, numa representação de "segunda ordem 
ou de ordem superior", ela pode segurar a banana próxima a sua boca e "falando" nela, afirma que a banana, agora, é um telefone.

Tratar um objeto como se fosse outro é a forma principal de "metarepresentação". Nos brinquedos de faz-de-conta, outras ordens meta-representacionais também podem ser encontradas. Por exemplo, alguém pode tratar nada como se fosse algo: "beberei um chá nesta xícara”, ainda que a xícara esteja vazia.

\section{O desenho}

Observando o desenho infantil como uma evocação representativa de um objeto, ele pode indicar os múltiplos caminhos que a criança usa para registrar percepções, conhecimentos, emoções, vontade, imaginação, memória no desenvolvimento de uma forma de interação social, apropriada as suas condições físicas, psíquicas, históricas e culturais. Por estas razões é que a representação pictográfica tem sido objeto de estudo de psicólogos, psiquiatras, sociólogos, pedagogos, entre outros especialistas, os quais a considera um meio para o acompanhamento e a compreensão do desenvolvimento na criança.

Segundo Moreira (1999), a criança desenha pelo prazer do gesto, pelo prazer de produzir uma marca, criando em torno de si um espaço de jogo, silencioso e concentrado ou ruidoso seguido de comentários, canções ou histórias, mas sempre um espaço de criação lúdica.

No fim da fase sensório motora (11/2 a 2 anos) início da atividade pictográfica, o movimento é um rabisco incompreensível para o adulto: uma garatuja, ou seja, o desenho não tem compromisso com representação de qualquer espécie. Aos poucos este desenho vai assumindo outras formas.

No jogo simbólico, que surge no período pré-operacional (3 a 4 anos) o desenho começa a se estruturar como linguagem, pois é mais organizado do que na fase anterior (sensório motora), mas a cor ainda é arbitrária e a ocupação do espaço ainda não obedece nenhuma regra, que só aparece na fase seguinte, do jogo regulado.

A partir do jogo simbólico o desenho passa para jogo regulado - período operacional concreto (5 a 7 anos), tendo um compromisso com o real. Há uma busca 
crescente de que o objeto desenhado se assemelhe ao objeto real. A criança nesta fase se diverte criando personagens e situações diferentes, construindo histórias.

Segundo Piaget e Inhelder (1995), o desenho é uma forma de função semiótica que se inscreve a meio caminho, entre o jogo simbólico (que serve para adaptar a criança a um mundo social de mais velhos e transformar o real por assimilação às necessidades do "eu") e a imagem mental (representação do real). Os desenhos se manifestam na idéia representada: são os heróis, fadas, princesas encantadas, viagens intergalácticas, porém dentro de convenções visuais preestabelecidas, que buscam uma linearidade espaço-temporal.

Ferreira (1998) relata sobre o estudo que Luquet (1969) faz acerca do desenho infantil, apontando que este, produzido pela criança até 8/9 anos é realista na intenção, e esse realismo passa por diferentes fases. A partir de então, o autor propõe estágios de interpretação: realismo fortuito - desenho inteligível, com significação descoberta em seu desenrolar; realismo gorado - os elementos da cópia estão justapostos em vez de estarem coordenados num todo; realismo intelectual - o desenho apresenta atributos conceituais do modelo, sem preocupação de perspectiva visual.

A autora, em sua pesquisa, ancorada na teoria genética evolutiva de Vygotsky que se baseia no contexto histórico social para compreender os processos psicológicos do sujeito -, considera a representação pictográfica da criança o apoio para surgimento de diferentes forças constitutivas do processo psicológico.

Para Vygotsky (1991), o peso da explicação do desenvolvimento da criança está nos fatores sociais e não nos fatores biológicos, pois estes não dão conta dos fenômenos psicológicos. Ferreira (op.cit.:55), na análise dos desenhos, optou pela pesquisa etnográfica, pois esse procedimento permite a união dos dados empíricos com os teóricos, construindo um processo aberto e dialético. Paralelamente às observações, a autora pôde interpretar, criar hipóteses, reinterpretar e selecionar aspectos significativos de um contexto.

Durante a produção dos desenhos, Ferreira dialogou com as crianças com objetivo de buscar o engajamento delas na atividade proposta.

Com base na análise das figuras produzidas pelas crianças e na teoria histórico cultural (Vygotsky), a autora percebeu que o desenho pode indicar a necessidade da criança de significar. As figuras desenhadas têm significados atribuídos pela 
criança/autora, apresentando indícios dos objetos e não exatidão de suas formas. Assim, a criança desenha para significar sua imaginação, seu conhecimento, criando um modo simbólico de objetivação de seu pensamento.

\section{As imagens mentais}

As imagens mentais, assim como os desenhos, também são consideradas condutas de representação de um objeto ou acontecimento que envolve a construção de significantes diferenciados/signos.

Segundo a análise de Piaget e Inhelder (1995), parece ser nítida a diferença entre imagens mentais no nível pré-operatório (7/8 anos) e no nível operatório (após 7/8 anos). Neste, a criança chega às reproduções de movimentos e transformações (imagens antecipadoras), enquanto no período pré-operatório as imagens mentais da criança são sempre estáticas, com dificuldade sistemática de reproduzir movimentos ou transformações (imagens reprodutivas).

A partir destas considerações, os autores constatam que as imagens mentais constituem um sistema de símbolos/signos que traduzem o nível de compreensão préoperatória e operatória dos sujeitos.

Após os 7/8 anos, quando a imagem se torna antecipadora (em melhores condições para servir de apoio às operações), o progresso resulta da intervenção de contribuições exteriores, devido à formação das operações.

Vygotsky (1991), em sua teoria histórico cultural, explica a formação da imagem e o funcionamento mental, considerando fundamental a mediação semiótica, em que as imagens mentais registradas na memória e organizadas pelos signos (representações de objetos, idéias ou coisas) são mediadoras na relação homem/mundo. Assim, na visão histórica e cultural, a imagem mental torna-se elemento constituidor da consciência, compõe o conteúdo mental do homem e permite que ele opere mentalmente sobre o mundo. 


\section{CAPÍTULO 2}

\section{COMPREENSÃO E PRODUÇÃO NA CRIANÇA}

2.1 O papel da memória no processamento do discurso

Visto que o processo narrativo é construído através da compreensão e produção de recordações, acontecimentos passados ou fatos que poderiam ter acontecido, apresentamos a seguir algumas reflexões sobre a memória que consideramos pertinentes ao presente estudo.

Segundo Alvarez (2002:17):

"a memória é a capacidade de armazenamento de todas as formas de conhecimentos adquiridos por nós em nossas relações com o meio ambiente. É a capacidade de aprender coisas novas, relacioná-las com informações já gravadas e tirar novas conclusões das quais nos lembraremos depois".

De acordo com a autora, a memória pode ser definida como a alteração do comportamento em decorrência da experiência prévia. Neste sentido, do ponto de vista neural, envolve um conjunto de sistemas diferentes que apresentam como característica comum à capacidade de armazenar informações. E mais do que isso, a memória permite ao indivíduo acessar tais informações quando necessário, de forma flexível, em períodos variáveis de tempo após a aquisição. Dessa forma, as capacidades de armazenamento e de recuperação estão interligadas e têm importante papel na análise das informações.

O estudo do desenvolvimento da memória se tornou um campo popular de investigação quando os pesquisadores se dedicaram ao desenvolvimento da memória infantil.

É por volta do início dos 2 anos de vida que a recordação parece se tornar uma experiência mais consciente para a criança, como se algum tipo de representação mental do evento ou objeto passado estivesse presente na consciência focal. 
Tipos de memória

Todas as informações captadas são armazenadas no cérebro, e para cada espécie de informação existe um tipo de memória, por isso acredita-se que existam tantas memórias quantas são as experiências acumuladas.

De acordo com Adam (1985), o armazenamento das informações pode estar na memória de curto prazo, também chamada memória de trabalho e/ou na memória de longo prazo.

A memória de curto prazo permite analisar os sons, as letras, as palavras e as estruturas sintáticas com a finalidade de fornecer uma representação semântica sob a forma de orações. Porém, o espaço para armazenar as informações é limitado, por isso a duração delas nesta etapa é curta, permanecendo enquanto for útil e depois é descartada.

Caso ela tenha algum valor significativo, é então transferida para a memória de longo prazo. Este tipo de memória tem a capacidade ilimitada e serve para reduzir a sobrecarga da memória de trabalho. Ainda aqui, podemos armazenar dois tipos de memória: a episódica - recordações de experiências pessoais ou eventos, associadas a um tempo e/ou lugar particulares; e a memória semântica - informação que não está associada a um tempo ou lugar particular e inclui nosso conhecimento sobre palavras, linguagem e símbolos, seus significados, relações e regras de uso.

Portanto, as modalidades de curto e longo prazo de memória estão ligadas, transferindo informações continuamente de uma para outra. Quando necessário, o conteúdo da memória de longo prazo é transferido para o armazenamento da memória de curto prazo. A modalidade de curto prazo ou memória de trabalho recupera as memórias, tanto de curto quanto de longo prazo. 


\section{Memória Construtiva}

De acordo com Flavel, Miller \& Miller (1999), os estudiosos da memória construtiva compartilham com a visão de Piaget de que o armazenamento de informações é construção e a recuperação destas é reconstrução, ou seja, a memória é "cognição aplicada". Assim, a maioria das coisas que lembramos na vida cotidiana faz parte da memória construtiva, são eventos organizados e significativos de informações estruturadas.

Dessa forma, o ato de compreender e codificar na memória são processos semelhantes à assimilação piagetiana de "construção" de uma representação conceitual interna da informação (daí o termo memória construtiva). O que é geralmente construído e armazenado na memória pode ser descrito variavelmente como uma interpretação sensata, para o sujeito, daquilo que ele percebeu.

A recuperação também é um processo ativo e assimilatório de "reconstrução", mais do que uma cópia passiva e literal do que está armazenado na memória. Pois esta recuperação requer que o sujeito faça inferências a partir daquilo que está na superfície. E a capacidade de fazer inferências depende do conhecimento de mundo e do conhecimento lingüístico (habilidades de raciocínio) armazenado na memória.

Segundo Koch \& Travaglia (1997), o conhecimento de mundo corresponde a todas as informações adquiridas e armazenadas na memória do indivíduo. E este conhecimento é que vai permitir a realização de processos cruciais para a compreensão.

Estes processos se referem à construção de um mundo textual, em que a coerência é possível se houver correspondência, pelo menos parcial, entre os conhecimentos ativados a partir do texto e o conhecimento de mundo do receptor, armazenado em sua memória.

A construção do mundo textual se refere ao conhecimento partilhado, àquele que o emissor e o receptor têm com certo grau de similaridade. É este conhecimento partilhado, pelos interlocutores, que possibilita a ocorrência de maior ou menor grau de inferências na interpretação do texto produzido. Entende-se aqui por inferência, qualquer operação mental envolvendo o estabelecimento de relações entre elementos explícitos e não explícitos, que devem ser efetuadas para a compreensão de um texto. 
Ainda de acordo com os autores, uma vez que a coerência de um texto também pode ser entendida como um princípio de interpretabilidade, o conhecimento lingüístico é condição inicial para se conseguir interpretar um texto, já que, sem conhecimento da estrutura morfológica, sintática, semântica e pragmática da língua em que foi produzido o texto, sua interpretação se torna impossível.

A partir dos conceitos expostos (conhecimento de mundo e conhecimento lingüístico), notamos que a criança assim como o adulto tem uma memória construtiva, pois ela não poderia levar a diante conversas cotidianas se não pudesse fazer inferências, integrações, elaborações e reorganizações espontâneas.

Quando ela cresce, desenvolve capacidades de fazer inferências que permitem uma representação mnemônica plena, integrada e significativa daquilo que vivencia.

Nos fragmentos que seguem, podemos ver como a memória construtiva é processada; aqui as crianças foram solicitadas a produzir histórias, após terem ouvido duas narrativas (Fita Verde no Cabelo e Menina Bonita do Laço de Fita), a primeira é uma estilização (segue o mesmo enredo da história original, com pequenas modificações) da história de Chapeuzinho Vermelho, e a segunda trata da história do coelhinho que se apaixonou pela menina negra:

M: era uma vez quatro coelhinhos eles gostavam de brincar um sobre o outro brincavam de danÇAR de puLAR ...

(Yannick 5;0 e Mariana 5;0)

Y: era uma vez três patinhos que gostavam de passear todo dia na lagoa ... (...) é é eles também co ... é ... é $\ldots[\ldots]$

$\mathrm{M}:[\ldots]$ os três patinhos foram dormir ... existia o lobo ... lobo [...]

$\mathrm{M}:[\ldots] L O-B O M A U[\ldots]$

(Yannick 5;0 e Mariana 5;0) 
Como observamos, as crianças compreendem e codificam na memória as narrativas lidas pela pesquisadora, por meio da assimilação/construção de uma estrutura narrativa (era uma vez...), já esquematizada na memória, ou seja, é a expressão do conhecimento de mundo e do conhecimento lingüístico. No primeiro segmento, $\mathrm{M}$ inicia sua história fazendo inferência à segunda narrativa (quando insere os personagens - coelhinhos), e acrescenta novas ações praticadas pelos personagens - dançar e pular. No outro fragmento, Y inicia sua história, também com "era uma vez..."; e M dá continuidade, fazendo inferência a narrativa de Fita Verde no Cabelo, que embora não apareça, explicitamente, a figura do lobo, mas faz alusão a história de Perrault. Dessa forma, as crianças reconstroem as informações armazenadas na memória para recriarem as suas produções narrativas.

Segundo Flavell, Miller \& Miller (op.cit.:209), à medida que a criança adquire esquemas de histórias, cenas e scripts (conhecimentos sobre eventos rotineiros da vida real, tais como freqüentar uma creche, fazer um bolo ou ir à escola) para rotinas do cotidiano, ela automaticamente os empregam para processar construtivamente as informações no armazenamento e reconstruí-las na recuperação.

$\mathrm{Na}$ fase do desenvolvimento do esquema, ela processa informações incompatíveis com ele (por exemplo, um show de mágica no zoológico). Este processo forma uma memória episódica para um evento único, distinto da memória roteirizada (script). A criança mais velha e o adulto, devido ao seu grande repertório de scripts, processam rapidamente as informações compatíveis com o esquema, e então se concentram em processar as incompatíveis.

Já a criança pequena pode se lembrar somente das informações compatíveis com o script ou confundir as memórias episódica e roteirizada, porque a primeira fase, da confirmação do esquema, exigiu tanto esforço que ela não tem mais capacidade para a segunda fase, processar as informações incompatíveis com o esquema.

Assim, a criança mais jovem ainda está formando o script, e por isso não pode confirmá-lo e codificar eventos inesperados separadamente. 


\section{Metamemória}

Outro aspecto que consideramos relevante, de acordo com os autores, é a metamemória, conhecimento ou atividade cognitiva voltada para qualquer coisa mnemônica, ou seja, é uma espécie de metacognição que toma as iniciativas de memória como seu objeto.

Existem duas categorias de metamemória: o conhecimento metacognitivo relativo à memória; e o auto-monitoramento e auto-regulação.

A primeira categoria (conhecimento metacognitivo relativo à memória) é ainda dividida em três subcategorias: conhecimento mnemônico sobre as pessoas, tarefas e estratégias.

Em relação à subcategoria, conhecimento mnemônico sobre as pessoas, a criança adquire habilidades de reconhecer, identificar experiências de lembrar e esquecer quando elas ocorrem, diferenciando-as de outras experiências mentais como pensar, sonhar e perceber. Ainda segundo os autores, existem evidências de que conceitos primitivos de lembrar e esquecer comecem a ser formados durante os primeiros anos da pré-escola, como parte do desenvolvimento da "teoria da mente" ainda implícita na criança. Verificamos esse reconhecimento de pessoas no seguinte exemplo, em que estão Mariana (criança-narrador), Yannick (seu colega) e Priscila (pesquisadora):

M: o Yannick pegou os quatro coelhinhos ... estava passando uma menina que se chamava Priscila ... a Priscila também quis um (coelho) ... eles era irmão ((Priscila e Yannick))

M: (...) a Priscila falô assim ... me dá um ... Yannick

(Mariana 5;0)

No segmento mencionado, notamos que $\mathrm{M}$, insere em sua narrativa as pessoas reais da interação, ou seja, ela as reconhece e faz questão de colocá-las como participantes/personagens de sua história.

Quanto à segunda subcategoria, a criança descobre que um conjunto de itens vai ser mais fácil de lembrar se eles forem poucos em número, familiares e significativamente relacionados uns com os outros (ou seja, categorizáveis). Percebe também, que alguns requisitos dos testes de recuperação são mais exigentes do que 
outros. Por exemplo, repetir uma história palavra por palavra é um teste mais exigente de memória do que recontá-la com as próprias palavras. Podemos observar esta subcategoria da escolha da tarefa, no fragmento abaixo, em que a criança foi solicitada a contar uma história sobre o desenho que tinha feito, e ela mesma intitulou de Alice no País das Maravilhas:

\section{Alice no país das maravilhas}

1. M: ela ela abriu uma portinha caiu na maravilha viu um monte de borboleta e umas flores gravada com um sol BEM Longe... uma flor ela cheirou ... a outra arrancou e uma veio um tomate

2. M: (...) as nuvens redondas ... as nuvens redondas com um coração MARCADO [...]

(Mariana 5; 0)

Como vemos, M conta a sua versão sobre a história de Alice no País das Maravilhas, relatando tudo o que ela acha interessante no mundo da fantasia, com suas próprias palavras.

A subcategoria das estratégias de memória engloba uma gama ampla e diversa de atividades potencialmente conscientes que uma pessoa pode realizar voluntariamente como um meio para vários fins mnemônicos. Repetir verbalmente um número de telefone, no breve intervalo entre procurá-lo na lista e ir até o telefone, para discar é um exemplo cotidiano de estratégia mnemônica. A criança da pré-escola possui somente conceitos rudimentares a respeito dessas estratégias. Mas é capaz de articular estratégias de armazenamento e recuperação plausíveis, em resposta a problemas hipotéticos de memória. Ela adquire o conceito de evocação cognitiva e conhecimentos a respeito da natureza e do uso de pistas de recuperação.

Nesta subcategoria, percebemos na interação da produção de histórias com criança, de 5 anos, que ela freqüentemente, antes de iniciar a atividade proposta pela pesquisadora (de contar histórias a partir de desenhos feitos pela própria criança), repete muitas vezes "era uma vez...", na tentativa de lembrar que tem que narrar uma história.

A segunda categoria (automonitoramento e autoregulação) pode ser considerada um conhecimento metacognitivo aplicado em relação à memória. A criança aprende a avaliar seu estado de memória atual, a selecionar estratégias, a avaliar seu progresso em 
direção a uma meta. O objetivo principal desta fase é levar a criança a identificar maneiras para que generalize suas estratégias em várias situações, e isto tem sido um obstáculo a todas as tentativas de ensinar estratégias.

Concluindo, diríamos que a explicação mais simples e direta para o desenvolvimento da memória se deve ao fato de que sua capacidade aumenta por causa da maturação biológica.

Para os autores citados, a capacidade é uma parte do legado da abordagem do processamento de informação, e também é considerada uma tendência evolutiva presente dos 6 anos até o fim da adolescência. Ou a capacidade funcional (a utilização total da memória) aumenta à medida que a criança aprende a lidar com as informações mais eficientemente, talvez as processando mais rapidamente.

Como vemos, a capacidade de memória pertence ao espaço de trabalho mental total disponível para os processos mentais básicos durante a codificação, a recuperação ou o uso de estratégias. Conforme os processos mentais básicos, tais como identificar palavras é mais praticado, eles se tornam mais rápidos e exigem menos esforço. Assim, a capacidade liberada pode ser dedicada a estratégias ou a o armazenamento de mais itens.

Da mesma forma, executar uma estratégia passa a ser menos exigente com o aumento da idade, liberando assim a capacidade para outras atividades mnemônicas.

\subsection{Alguns estudos sobre compreensão e produção}

A compreensão e produção nos estágios iniciais do desenvolvimento lingüístico fazem parte de um dos dilemas da Psicolingüística Desenvolvimental. O interesse dos estudiosos da aquisição da linguagem nessa interação compreensão e produção se apóiam na idéia de competência lingüística definida por Chomsky (1965), ou seja, competência vista como o conhecimento tácito de regras gramaticais.

No caso da criança pequena, julgamentos quanto à gramaticalidade de sentenças e correções de sentenças agramaticais só poderiam ser obtidos, com muito engenho e arte, após os 4 ou 5 anos de idade. (De Villers \& De Villers, 1973). O acesso a competência lingüística da criança estaria assim limitado basicamente à observação de sua fala espontânea, o que traria o risco de super ou subestimar essa competência. 
Observações naturalísticas (interação com a mãe no ambiente familiar) do comportamento infantil parecem indicar que a criança entende muito mais do que produz. Mesmo antes de produzir qualquer enunciado, a criança parece estar entendendo as informações (ou alguma delas) dirigidas a ela pelo seu interlocutor adulto, o que leva o estudioso da compreensão infantil à hipótese de que a compreensão precede a produção.

Sabinson (1982) cita alguns estudos da compreensão infantil testada em situações de interação não naturais, situações que nada têm a ver com as situações normais de interação que a criança está acostumada no âmbito familiar. Nesses estudos, a criança interage com um pesquisador desconhecido, que observa a produção de sentenças ativas reversíveis (ex: João chutou Paulo e Paulo chutou João). A partir daí os estudiosos notaram que a fala espontânea da criança obedece consistentemente à ordem de palavras, única dica para o significado da sentença quando esta ocorre isoladamente, sendo o nome identificável como agente ou objeto da ação apenas por sua posição na seqüência. Aqui a produção parece preceder a compreensão.

A relação entre compreensão e produção não é clara e também não é uma questão de tudo ou nada em que "a primeira é uma questão de graus, e que os processos envolvidos na compreensão infantil não seriam necessariamente os mesmos da compreensão adulta, havendo ainda diferenças individuais nas estratégias empregadas pela criança", como afirma Bridges (1980).

A experiência da criança com o mundo dos objetos vai determinar a maneira pela qual ela considera esses objetos num experimento, o que pode influir no resultado obtido. Então, uma criança acostumada a ver e brincar com barcos de brinquedo pode interpretá-los como veículo do tipo carro ou caminhão, o que a levaria a fornecer uma interpretação incorreta do ponto de vista do pesquisador para ordens do tipo "ponha o barco na/em cima da ponte".

A compreensão infantil passaria, assim, por estágios tais como interpretação pragmática, interpretação semântico-pragmática, interpretação sintática, sendo a habilidade de compreender mensagens lingüísticas isoladas, uma aquisição relativamente tardia no desenvolvimento da linguagem.

Karmiloff-Smith (1979) observa que somente após os 8 anos de idade a criança seria capaz de interpretar consistentemente enunciados fora do contexto, confiando 
apenas em "dicas" lingüísticas, o que, segunda a autora, seria indicação de que essa criança teria atingido um nível mais abstrato de competência lingüística. Antes disso, a compreensão infantil dependeria de múltiplos fatores de interação, fatores não apenas sintáticos, mas também semânticos, pragmáticos, intonacionais, pressuposicionais, concernentes às regras dialógicas e ao contexto discursivo e situacional.

Fayol (1985) cita alguns estudos sobre a compreensão de crianças de 7 e 9 anos e compara com a compreensão dos adultos, em histórias que têm ou não um obstáculo que se opõe à realização do objetivo. E verificou a presença de questões - quem?, o quê? como? - tanto por parte dos adultos quanto das crianças. Esse método permite um estudo do desenvolvimento da compreensão e em particular das inferências.

Numa segunda experiência, o autor coloca em evidência uma correlação entre os resultados das inferências contextuais (proposições e conseqüências prováveis dos acontecimentos) e o resultado das produções de narrativas livres.

Por meio de uma análise de regressão múltipla, percebeu que a capacidade de inferência e de responder as questões aumenta com a idade. Porém, mesmo as crianças mais novas se revelam capazes de expressar as informações explícitas para estabelecer as relações entre os acontecimentos. Como vemos, esta é uma habilidade muito precoce. Outro fator relevante nesses estudos é a forma sintática do texto, que condiciona a compreensão.

Assim, compreender um texto e em particular uma narrativa significa construir uma representação mental (já mencionado anteriormente), assimilando os elementos que a constituem em uma estrutura de conhecimento prévio, mas que de fato se encontre modificada (Fayol, op.cit.:45). 
Sobre a compreensão de narrativa

De acordo com Adam (1985:64), uma narrativa não é compreendida nem memorizada de forma linear. Os trabalhos de psicologia cognitiva centrados no processo de memorização, de (re) produção, de compreensão de textos, nos permitem adiantar um certo número de hipóteses.

Segundo a autora, os trabalhos narratológicos estruturalistas e semióticos adquiriram uma nova perspectiva do que sabemos atualmente das estruturas, quando os consideramos na representação cognitiva de um texto armazenado na memória. A interdisciplinaridade é, ainda hoje, indispensável e importante para dar conta do que os psicolingüistas e outros teóricos da leitura pensam não só sobre o que percebemos, interpretamos, compreendemos, e também escolhemos e organizamos informações.

Os testes de memorização e de resumos (Adam, op.cit.:67), mostram que os sujeitos conseguem resumir sem dificuldades as novelas do Décaméron, a introdução de um mito "apache" (pertencentes a tribos indígenas), a origem do milho ou do "gamo" (animal asiático) semelhante ao veado, mas que tem a cauda comprida e a parte superior dos galhos achatada e palmada), faria oposição imediatamente:

\footnotetext{
"A história indígena que escolhemos (...) não contém nenhuma frase difícil nem palavra rara (colocariam no lugar os nomes raros). Todavia, nossos sujeitos acharam a história estranha, pois ela não se adaptaria às suas expectativas em matéria de narrativas: o personagem do herói varia, os episódios se seguem sem nenhuma ligação aparente (quer dizer casual). A organização da história é obscura. A história, é claro, segue uma ordem bem estabelecida, mas conhecida unicamente dos Índios e dos antropólogos". Kintsch e van Dijk (1975 apud Adam, 1985:12)
}

A partir do exemplo citado, os autores levantam a hipótese de que não memorizamos quase nada do que compreendemos, e que compreendemos, sobretudo, o que reconhecemos. Os sujeitos testados não dispunham, para organizar seu resumo, de um esquema implícito (macroestrutura semântica ligada aos seus conhecimentos do mundo e aos cenários armazenados na memória) referente ao mito "apache", mas também de uma superestrutura narrativa.

Dessa forma, o leitor/ouvinte chega a um discurso narrativo porque possui em sua consciência o esquema pré-construído e um conjunto de representações. 
Assim, compreender é, em parte, reconhecer e operar uma espécie de preenchimento das casas vazias de um esquema armazenado na memória com a ajuda de informações provenientes do texto.

\section{Sobre a produção de narrativa}

Contrariamente ao que ocorre na compreensão de narrativa, segundo Fayol (op.cit.:130), na produção, o sujeito não tem de inferir de uma intenção e/ou um conteúdo. Em geral, ele dispõe previamente de um repertório potencial (esquema armazenado na memória), o qual se estrutura em função de três parâmetros:

a) um acontecimento referente ao objeto da narração;

b) um audiência ou ritual;

c) uma situação de enunciação definida pelos lugares, momento e interlocutor.

Dessa forma, o sujeito deve dispor de uma representação mental dos princípios de organização das seqüências de ações (objetivo - plano; razão -ação; acontecimento conseqüência) para compreender a organização das cadeias circunstanciais e explicá-la. Em seguida, é preciso que ele, por meio de uma audiência ou ritual, assegure que o acontecimento escolhido desperte o interesse de seu destinatário real, que se manifesta através das reações efetivas.

Trabalhando com as crianças as quais a autora pede em condições naturais e realistas para relatar um acontecimento anteriormente ocorrido, Quasthoff (1985, apud Fayol, op.cit.:131) ela descobre que a narração (a narrativa ainda em curso) aparece sempre primeiro e que a passagem para a narrativa (o texto já pronto) depende da intensidade do interesse manifestado pelo ouvinte.

Labov (1972) também considera este aspecto (manter o interesse do interlocutor) relevante na produção de histórias orais de experiências pessoais, em que o narrador, estrategicamente, antecede as avaliações - os pontos de vista dele em relação ao que se conta. Dessa forma, ele consegue manter o interesse do interlocutor na participação do processo narrativo. A reação do interlocutor é colocada em prova em relação ao que será dito (ele está interessado?), se a resposta for positiva, é suficiente para continuar 
esta atividade, se a resposta for negativa, então o narrador introduz uma avaliação (uma das partes da estrutura narrativa já discutida).

Evidentemente, na escrita, a produção não pode se desenvolver da mesma forma. Então, o autor escolhe um tipo discursivo e um interlocutor imaginário, mesmo que este não responda realmente, pois isto não impede o desenvolvimento da narrativa.

Como vemos, existem muitas estratégias discursivas para se contar um fato oralmente, e devemos levar em conta o implícito e os efeitos de diferentes variações textuais, pois de acordo com F. François (1996) estamos num espaço de jogo, onde o erro não tem conseqüência dramática, onde podemos voltar atrás, permitindo à linguagem funcionar plenamente. E, neste espaço, mencionado pelo autor, o discurso é co-produzido, e o resultado é um trabalho de colaboração entre os participantes da interação. 


\section{CAPÍTULO 3}

\section{MÉTODO}

\subsection{Procedimento adotado na coleta dos dados e escolha do material}

Este trabalho foi desenvolvido a partir de uma pesquisa transversal realizada com 6 (seis) crianças brasileiras, de cinco anos de idade, de ambos os sexos. As crianças, durante o período da coleta de dados, foram observadas na interação criançacriança, em suas produções pictográficas e narrativas. A partir de então, suas falas foram gravadas em fita-cassete.

Tendo em vista que se trata de um estudo com crianças em idade pré-escolar, a pesquisa transversal foi realizada em duas pré-escolas, no Instituto Educacional da AABB (Associação Atlética do Banco do Brasil) e também no Instituto de Educação Infantil e Fundamental Henrique I.

Apoiando-nos em algumas pesquisas de Spinillo (1991), sobre a produção de narrativas com apoio de desenhos, as crianças foram solicitadas a produzirem narrativas orais em duas situações:

a) elaboração de histórias a partir de uma representação pictográfica (desenho feito pelo sujeito);

b) elaboração de histórias sem o apoio do desenho, mas tendo como suporte histórias lidas em voz alta pela pesquisadora.

Considerando as situações apresentadas, os materiais utilizados na situação (a) foram: lápis de cor, canetinha, folhas de sulfite, para que as crianças desenhassem e posteriormente contassem uma história; e na situação (b), foram lidos pela pesquisadora dois livros de histórias infantis, "Fita Verde no Cabelo: nova velha estória", de João Guimarães Rosa e "Menina Bonita do Laço de Fita", de Ana Maria Machado, servindo de estímulo para a produção de narrativas. 
Esta pesquisa constou de uma sessão semanal de trinta a quarenta e cinco minutos de duração, com intervalo de quinze dias entre um encontro e outro (total de 6 sessões), distribuídas em três meses, (sendo as 4 primeiras coletas realizadas durante os meses de março e abril de 2003 e as outras 2 sessões no mês de março de 2004).

Os dados foram gravados em fitas de audiotape e transcritos com base nas normas do Projeto NURC/USP - Projeto de Estudo da Norma Lingüística Urbana Culta de São Paulo (Preti e Urbano, 1990), (ver anexo 1).

\subsection{Seleção dos sujeitos}

As crianças foram selecionadas entre 3 meninas e 3 meninos, sendo as duas primeiras crianças (Yannick e Mariana) da pré-escola da AABB - Associação Atlética do Banco do Brasil, e as outras quatro (Beatriz, Jeniffer, Fernando e Victor Hugo) do Instituto de Educação Infantil e Fundamental Henrique I.

A faixa etária escolhida, cinco anos, é a fase que antecede o início do processo formal de alfabetização (seis e sete anos), ou seja, a criança não tem ainda o domínio efetivo dos códigos da escrita, mas já é capaz de produzir histórias orais.

Parafraseando F. François (1996), diríamos que se trata de uma seção da préescola, onde se destaca o desenvolvimento da linguagem por meio da produção de narrativas, prática de monólogos ou diálogos entre outros.

Gardner (1994:54) também alinha elementos que possibilitam a compreensão de características do pensamento infantil e afirma que "capacidades simbólicas particulares refletirão as práticas peculiares da cultura ou subcultura, mas a capacidade simbólica é uma aquisição universal da primeira infância".

$\mathrm{O}$ autor ainda explicita que na idade de cinco ou seis anos, as crianças desenvolvem sentidos vigorosos de três dimensões de modo relevante. No mundo dos objetos físicos, desenvolvem uma teoria da matéria; no mundo dos organismos vivos, desenvolvem uma teoria da vida; e no mundo dos seres humanos, desenvolvem uma teoria da mente que incorpora uma teoria do self.

Nesta perspectiva, elas são capazes de se posicionarem em relação aos acontecimentos cotidianos e conseqüentemente opinam em suas produções orais de 
narrativas apresentando argumentos, justificativas e explicações durante o desenvolvimento da narração.

Com o objetivo de esclarecer melhor os dados coletados, caracterizamos, a seguir, os sujeitos selecionados, do ponto de vista pessoal e familiar:

YANNICK - entrou na creche com 12 meses, filho único de mãe funcionária do Banco do Brasil; escolaridade: superior completo (gerente) e pai economista.

MARIANA - entrou no Jardim I com 2 anos, filha única de mãe funcionária da préescola da AABB (Associação Atlética do Banco do Brasil); escolaridade: mãe pedagoga e pai vendedor.

BEATRIZ - entrou na creche com 2 anos, tem 1 irmã de 8 anos; a mãe é professora e o e pai advogado.

JENIFFER - entrou na creche com 1 ano, filha única de mãe funcionária do Instituto Educacional e Fundamental Henrique I, escolaridade da mãe: cursando Pedagogia e pai professor.

FERNANDO - entrou na creche com 2 anos, filho único de mãe nutricionista e pai advogado.

VICTOR HUGO - entrou na creche com 3 anos, filho único de mãe professora e pai corretor de imóveis.

Neste estudo transversal, após a apreciação dos objetivos da pesquisa, respectivamente pelas diretoras e coordenadoras das duas pré-escolas, e de algumas conversas paralelas com as mesmas a respeito do que pretendíamos, os sujeitos foram então selecionados de acordo com os critérios que seguem:

a) inexistência de comprometimento e/ ou distúrbios de linguagem; 
b) autorização prévia dos pais;

c) disponibilidade das crianças no horário sugerido pelas coordenadoras de ambas as pré-escolas - por volta das $9 \mathrm{~h}$ ou $10 \mathrm{~h}$, quando a maioria das crianças estava acordada, e não estava fazendo nenhuma atividade programada pelas professoras.

\subsection{Esclarecimentos complementares}

É importante comentar, também, algumas características referentes aos espaços físicos, em que se realizou a presente pesquisa.

Os ambientes selecionados das duas pré-escolas são considerados padrão, pois possuem uma infra-estrutura pedagógica satisfatória, visando não só a alfabetização das crianças, mas também preparação destas para o mundo.

Pode-se dizer que elas dispõem de relativa liberdade e independência, considerando que, quando não estão em atividade, têm permissão para circular pelas pré-escolas: quando sentem sede, podem se servir de água, quando têm sono podem dormir...

Tal clima de descontração e, ao mesmo tempo, de seriedade faz com que as crianças se tornem mais responsáveis, uma vez que cada uma aprende a preservar o espaço em que vive e a zelar pelo material que usa.

Tanto a primeira quanto à segunda pré-escola dispõem de uma sala de leitura local onde foi realizada a pesquisa - com mesas, cadeiras, almofadas espalhadas pelo chão e estantes com livros.

O nível sócio-econômico-cultural dos sujeitos é bem heterogêneo, dado que a Instituição da AABB (Associação Atlética do Banco do Brasil), por estar vinculada a um clube, dispõe de vagas para filhos de sócios e funcionários do mesmo estabelecimento; o Instituto de Educação Infantil e Fundamental Henrique I também apresenta um perfil sócio-econômico-cultural dos sujeitos misto. Embora essas diferenças sociais possam refletir nas produções das crianças, elas não serão levadas em consideração nesta pesquisa, pois não é nosso objetivo analisar seus efeitos nas produções dos sujeitos. 
No entanto, este conjunto de características, que incluem o espaço pedagógico onde as crianças se inserem, bem como suas vivências cotidianas, nos ajudam a caracterizar o perfil dos sujeitos estudados, e conhecer parte de seu universo cognitivo, que se reflete na produção de narrativas.

\subsection{Os fios condutores da análise}

Neste item apresentamos os fios condutores utilizados na análise dos dados, levando em consideração os aspectos interpretativo e lingüístico da comunicação verbal e não-verbal, ou seja, os gestos (de apontar, arregalar os olhos, levantar os ombros, etc), pois eles contribuem significativamente na medida em que revelam as intenções das produções narrativas e seus efeitos, no que se refere a habilidade lingüística da criança pequena.

Neste sentido, abordamos alguns tópicos, de forma não exaustiva, que julgamos pertinentes no presente estudo, no momento da análise.

Assim, os autores como Bruner, Fávero, Fiorin, F. François, Koch, Marcuschi, Perroni, Possenti e Vygotsky são os estudiosos que nortearam a análise dos dados na comunicação verbal - alguns de modo mais direto, outros apenas como pano de fundo além dos autores citados no quadro teórico que dão suporte à questão da estrutura narrativa, privilegiando então Labov (1972), no que diz respeito à avaliação, com objetivo de articulá-la à explicação.

Tendo em vista que toda narrativa relata mudanças progressivas de estado (mencionado no quadro teórico), e que estas mudanças giram em torno das ações dos personagens, cabe-nos agora visualizar em um quadro as categorias de análise, identificadas nas produções narrativas das crianças: expressões de estado mental (EM); atribuições implícitas (AI); uso do discurso direto com variação da entonação (DD) e enfoque no ponto de vista do personagem principal (EPP). 
Quadro 2 - O papel dos personagens nas produções de histórias orais

\begin{tabular}{|c|c|c|}
\hline Categorias de análise & Descrição & Exemplos \\
\hline EM & $\begin{array}{l}\text { Pensamentos/crenças dos } \\
\text { personagens }\end{array}$ & $\begin{array}{l}\text { "a menina comprou a } \\
\text { boneca que tanto sonhava" } \\
\text { (ou seja, ela quis e pôde ter } \\
\text { o que desejava) }\end{array}$ \\
\hline AI & $\begin{array}{l}\text { Sentimentos } \\
\text { personagens }\end{array}$ & $\begin{array}{l}\text { "o menino tropeçou na } \\
\text { pedra e começou a chorar" } \\
\text { (logo, o menino ficou } \\
\text { triste) }\end{array}$ \\
\hline DD & $\begin{array}{l}\text { Reprodução da fala dos } \\
\text { personagens com alteração } \\
\text { no tom de voz do narrador }\end{array}$ & $\begin{array}{l}\text { M: [...]"ONde que VOCÊS } \\
\text { pegaram essas coisas ... } \\
\text { esses coelhinhos?”[...] }\end{array}$ \\
\hline EPP & $\begin{array}{l}\text { Enfoque no ponto de vista } \\
\text { do personagem principal - } \\
\text { ou seja, a atitude (ação) } \\
\text { dele na história }\end{array}$ & $\begin{array}{l}\text { Y: "[...] e o pássaro da paz } \\
\text { veio e deu a paz" } \\
\text { M: (...) tentaram pegar (o } \\
\text { pássaro) porque ele é muito } \\
\text { bonzinho (pelo fato de o } \\
\text { pássaro ter dado a paz, } \\
\text { conclui-se que ele é bom) }\end{array}$ \\
\hline
\end{tabular}

Para análise da comunicação não-verbal, os gestos (de apontar, arregalar os olhos, levantar os ombros entre outros), nos apoiamos em Rector e Trinta, Davis e Guiraud.

Levando em conta que a produção de narrativa oral ocorre na interação criançacriança, e também, criança-adulto, em que este pode auxiliá-la no desenvolvimento de sua narração, temos a concretização de tutela, que discutimos a seguir. 
O papel da interação com tutela na construção de narrativas orais (a tutela segundo Vygotsky e Bruner)

De acordo com Mac-kay (2000), a noção de tutela segundo Vygotsky, é mediada por intervenções entre o adulto e a criança num processo de aprendizagem da linguagem, é o adulto ajudando a criança a fazer algo que ela não pode fazer sozinha. Lembrando da idéia fundamental de Vygotsky, de "Zona de Desenvolvimento Proximal (ZDP)", onde não há um desenvolvimento puramente interno do sujeito, em que o adulto pode ajudar a criança quando esta não pode dominar sozinha a atividade em questão. Esta zona "pedagógica" fica entre aquela em que a criança pode fazer alguma coisa sozinha e a outra, em que a tarefa é muito difícil para a criança e ela não consegue resolver. A tutela se transforma em contra-tutela se o adulto repetir para a criança o que ela já sabe, ou se ensinar o que ela não pode integrar.

Bruner (1991) expõe sua concepção de tutela a partir de uma experiência "interessante" com crianças de 3 a 5 anos: construir uma pirâmide de seis andares com 21 blocos de madeira, em que o tutor auxilia as crianças de seis maneiras: 1) engajamento - criar interesse pela tarefa; 2) redução de graus de liberdade - cada tarefa pode ser analisada em subtarefas; 3) manutenção da orientação - manter a criança no objetivo proposto; 4) sinalização das características determinantes - atrair a atenção da criança; 5) controle da frustração - encorajar a criança; e 6) demonstração - mostrar a criança como se faz.

A apresentação do conceito de tutela em Bruner tem sentido preciso, porém está ligado às condições particulares da experiência, e se quisermos verificar a tutela na situação de discurso, outros aspectos devem ser levados em conta, pois na linguagem a criança é, muitas vezes, capaz de usos dos quais o adulto é incapaz (por exemplo, a espontaneidade no dizer).

Portanto, toda iniciativa de fala pode ser considerada sob dois pontos de vista: precisão pragmática semântica ou correção formal. Tem-se também o componente "imaginário" na situação real, em que cada um percebe, enfatiza e organiza a situação; por exemplo, o silêncio da criança, suas hesitações, seus erros, e o inesperado de seu discurso, constituem um quadro de tutela e não de interação verbal. 
Partindo da idéia de que a tutela não é uma meta, mas sim um resultado, suas modalidades, caracterizam os efeitos produzidos no sujeito tutelado.

De acordo com F. François (1996), podemos elencar dois tipos de tutela: a global e a local. A primeira faz com que a situação de diálogo seja em si mesma portadora de uma atmosfera, de um sentido que lhe é próprio e está ligada àquilo que a simples presença do tutor num dado contexto situacional, representa para acriança; a segunda (tutela local), baseia-se naquilo que se faz com determinado enunciado, gesto ou olhar num dado momento da interação. Os efeitos podem ser os mais diversos, positivos ou negativos, esperados ou inesperados, provocar mudanças ou misturas de mundos, e até mesmo, configurar correções ou aprovações.

A tutela local propicia condutas comportamentais da criança, em resposta às perguntas do adulto que exemplificamos a seguir, considerando $\mathrm{P}$ para pesquisadora $\mathrm{e}$ CA para a criança.

A tutela paralela estrita ocorre quando o adulto faz o que a criança deveria fazer. No exemplo abaixo, CA e P conversam sobre o objeto - varinha mágica - que aparece na história de um livro. A pesquisadora faz a pergunta e ela mesma fornece a resposta esperada pela criança:

CA: ai tavam discutindo lá ... daí()

P: o que era? uma varinha mágica

CA: varinha mágica! ela gostou e agradeceu

Na tutela paralela por esboço, o adulto começa o que a criança deve terminar, na situação que segue a criança está contando uma história mostrando o livro para a pesquisadora:

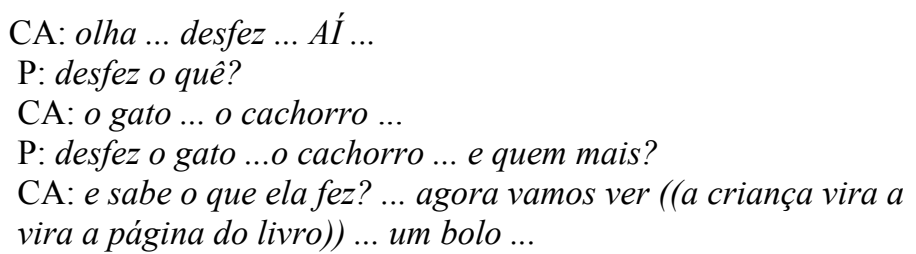


Observamos, além do efeito de tutela, como a criança se coloca no papel do eu e do outro; um eu narrador que cria certa expectativa no ouvinte - que tanto pode ser o outro/ ele mesmo (eu que responde) - através da inserção de uma situação suspense.

A tutela complementar consiste em favorecer a ampliação da produção da criança. No exemplo que segue, CA na iteração com $\mathrm{P}$ discutem a razão da queda de um vaso, fato que ocorreu poucos minutos antes da conversa:

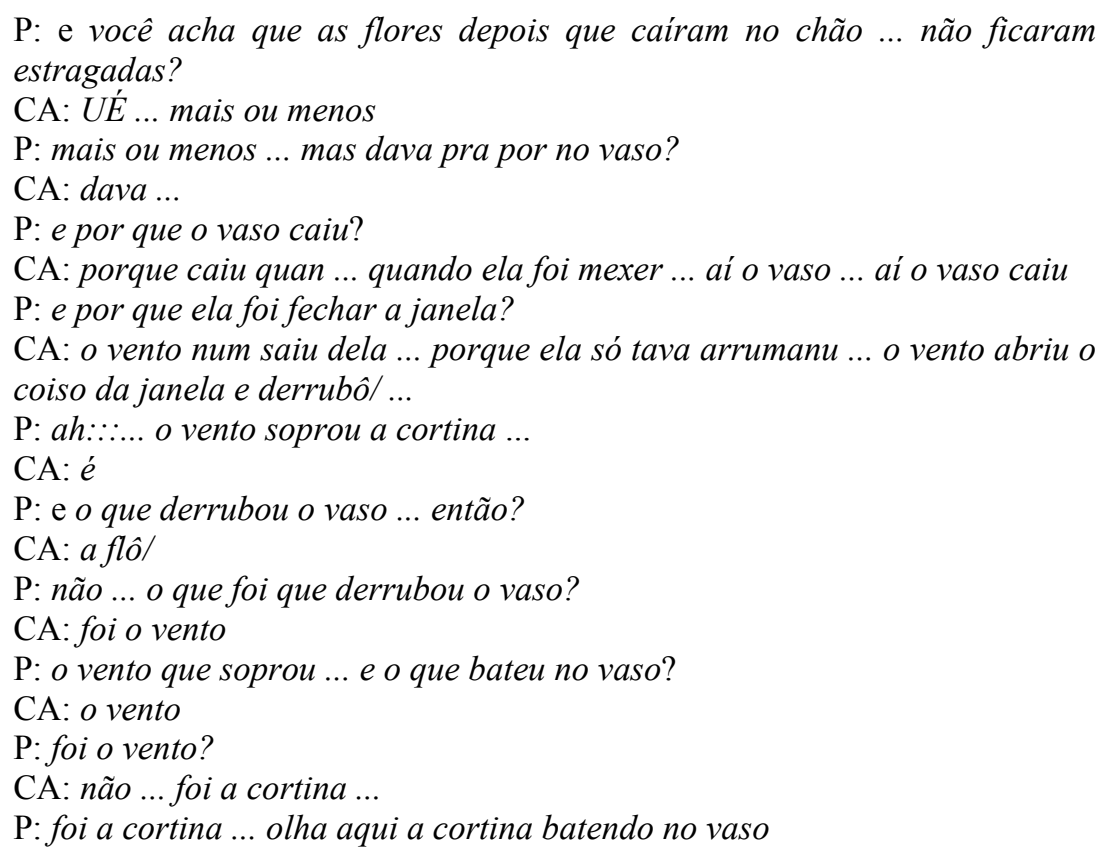

Como vemos, o resultado das perguntas é a ampliação da produção da criança, caracterizando a tutela complementar.

$\mathrm{Na}$ tutela metalingüistica a criança desenvolve, modifica e resume, fazendo retomadas/ modificações do discurso do outro. O próximo fragmento referente a uma passagem do livro "Na casa velha da praia", verificamos esta tutela, por meio do diálogo entre CA e P:

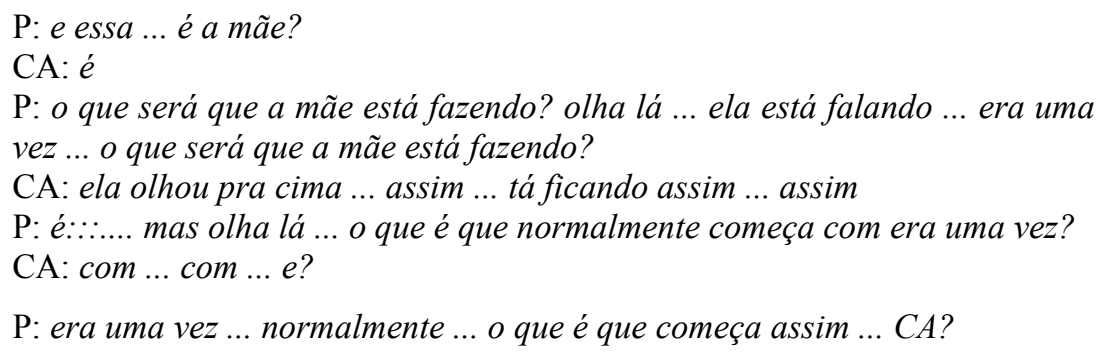


CA: era uma vez ... começa ... mas ... mas uma ...

CA: um dia ... meu pai ... ele já contou história pra mim ... mas era do Deus

P: então ...

CA: mas ele não falou era uma vez ...

P: mas aqui na creche você escuta um monte de histórias que começam ... era uma vez ... há muitos e muitos anos atrás ... não é? então ... eu acho que a mamãe estava contando uma história para as crianças ....

CA: $e$

P: era uma vez ... olha só ...

CA: meu pai fala assim ... que é assim ... quando eu falo ... era uma vez ... o meu pai fala assim ... eu falo uma vez ... era uma vez ... o meu pai fala ... um gato chinês ...

Aqui, o adulto procura fazer a criança perceber através da imagem, o que o personagem está fazendo: contando uma história. Como a criança não apreende o sentido pela leitura icônica, P sugere a ela o marcador inicial que convencionalmente é utilizado para introduzir histórias tradicionais do gênero infantil: "era uma vez". CA passa então a relatar uma experiência pessoal, refutando o que lhe foi apresentado como modelo convencional. Demonstra por duas vezes que já tem o conceito ampliado de contar histórias (sobre Deus) que não começava com "era uma vez" ..., e também ao se referir a uma situação de uma brincadeira verbal (do gato chinês), que começa com este operador. Brincadeira, diga-se de passagem cuja estrutura inicial tem a função de criar expectativa no ouvinte de que vai ouvir uma narrativa, mas que, na realidade, não passa de um jogo verbal. Dessa forma, verificamos no discurso de CA, uma função referencial do operador de construção de mundo "era uma vez" ..., pois ele age como um marcador de ficção que suspende as condições habituais de validade das proposições, e abre um novo espaço semântico.

A tutela com efeito inesperado, ocorre quando a criança estabelece a mistura de mundos (real x imaginário) ao responder uma questão que lhe é solicitada, apresentando uma situação ora clara, ora obscura, pois o inesperado pode surgir como podemos ver no diálogo entre P e CA:

CA: ... quando aí ela passou no ... aí né? ... ela atravessou a rua ... quando ela foi ... ela foi bem devagarzinho ... tomando cuidado pra não atropelar ... pronto já contei

P: muito bem ... e....... você atravessa a rua sozinha?

CA: travesso

P: é mesmo? quais os cuidados que você toma pra atravessar a rua?

CA: oh ... vão devagar ...

P: só isso?

CA: sabia que eu num ... que eu invés deu ... eu vou atravessando as rua dan ... assim dando cambalhota ... 
P: não ... não diga ... você atravessa a rua ... e se vier um carro ... você não vai ver

CA: não ... não ... um dia eu vi um carro ... aí fez zum...... lá no alto e pulei no chão

P: e o carro parou?

CA: parou não ... andou e caiu em cima do ônibus ...

P: que perigo ... hein ... que perigo ...

Notamos que a partir da pergunta de $\mathrm{P}$ “" só isso?”, CA passa a elaborar um relato de experiência pessoal pautado em seu universo imaginário. $O$ efeito da tutela é inesperado, uma vez que a expectativa era de que a criança pudesse elencar uma série de cuidados que se deve ter ao atravessar uma rua.

Além das modalidades expostas, o autor ainda cita mais uma situação - a tutela insistente que pode se transformar em contra-tutela, se P fizer inúmeras perguntas com o objetivo de fazer a criança falar, propor uma atividade que seja muito fácil ou difícil (já discutido em Vygotsky), desestimulando a mesma. Podemos verificar este tipo de tutela no exemplo seguinte, em que $\mathrm{P}$ e CA estão numa sala que tem retroprojetor, e a primeira solicita a segunda que reconte a história - "Isto não se faz":

CA: Ricardo pares andando com seu cachorro ... e...... "Ricardo”... ((alguém chama por Ricardo)) Ricardo olhou para trás ... num viu nada ... depois olhou ... ficou olhando ... ai bateu a cabeça no poste ... aí...... é isso que o cachorro queria ... ai acabou

P: acabou? ah:: o que você acha do amigo ter chamado o amigo e ter se escondido ... hein?

CA: tem figura ... num mostra na parede? ((a criança se desinteressa pela atividade proposta, se interessando por outra coisa))

$\mathrm{P}$ : não mostra nada na parede ... você está falando lá do retroprojetor?

CA: é ... e se pôr essa figura?

P: também não aparece ... não é transparente

CA: uhm:..... se pôr essa?

P: também não

CA: e essa ... essa ... essa?

$\mathrm{P}$ : essas figuras ... nenhuma aparece

Percebemos, primeiramente, que a criança não consegue avaliar a situação apresentada pela história original, mudando seu sentido ao fazer uma leitura polissêmica (... é isso que o cachorro queria); em seguida, diante da impossibilidade de responder à pergunta da $\mathrm{P}$, desvia sua atenção para um objeto do mundo real (o retroprojetor). 
Observamos na maioria das vezes, que é o adulto em geral que inicia a troca, são as perguntas deste que diferenciam as díades na interação adulto-criança, e a partir dessa relação encontramos ou não questões acumuladas, questões com único organizador ou misturadas com afirmações, opiniões, aprovações. Por outro lado, temos questões categoriais partindo dos enunciados da criança.

Em relação ao modo de continuidade no discurso da criança com o do adulto, verificamos o discurso implicado (a criança mistura o seu discurso ao do adulto); discurso ligado (o discurso da criança e do adulto caminham juntos), que parece ser característica do modo conversacional e o discurso independente, que é elaborado pela criança sem o apoio do adulto.

Quanto à homogeneidade ou heterogeneidade do mundo no qual as intenções se permutam, a criança está numa posição diferente em relação aos propósitos do adulto; e as relações metadiscursivas de correção ou de aprovação aparecem mais com crianças menores.

Ainda uma observação a ressaltar, não se trata de responder a questão "como falar a, com, sua criança?", mas insistir em dois fenômenos: a complexidade de características estáveis (peculiaridades coletivas que pertencem à cultura) e, ao contrário, de estilos individuais, e perceber a importância das significações que se esboçam nos desnivelamentos, ou a organização global da troca por oposição às significações diretamente produzidas pelas colocações em palavras.

Os gestos

Considerando que o processo comunicativo se realiza na interação entre os sujeitos, por meio de códigos verbais e não-verbais, os gestos, que têm a função de completar a atividade verbal ou substitui-la, eles serão levados em conta aqui. Para tanto, apresentamos brevemente a tipologia e descrição dos gestos.

Segundo Rector e Trinta (1993), o gesto é uma ação corporal visível, pela qual certo significado é transmitido, e ele pode ser classificado em cinco categorias:

1) os emblemas - são signos que fazem parte da cultura brasileira e assim, são aprendidos (fazer uma figa ou dar uma banana); 
2) os ilustradores - são aprendidos por imitação, atos não-verbais que acompanham a fala para enfatizá-la;

3) os reguladores - gestos que regulam e mantêm a comunicação entre dois ou mais locutores; consistem em movimentos com a cabeça e com os olhos;

4) as manifestações afetivas - são configurações faciais que assinalam estados afetivos, o emissor tem consciência do que manifesta, mas às vezes tal gesto pode realizar-se inconscientemente, por exemplo, quando fazemos "cara feia", quando encontramos alguém com quem antipatizamos;

5) os adaptadores - são gestos que servem para mostrar nossa insegurança, quando não conseguimos dizer o que sentimos (roer unhas, manipular em forma de cacho o cabelo).

De acordo com Guiraud (1991), a manifestação de nossos sentimentos e emoções, por intermédio dos movimentos do corpo e das reações do organismo, corresponde a dados psicofisiológicos indiscutíveis, como exemplificamos no poema abaixo:

Sufocamos de raiva.

Babamos de admiração.

Fazemos careta de dor.

Pulamos de alegria.

Trememos de medo.

Ficamos inchados de orgulho.

Queimamos de desejo.

Ficamos lívidos (ou roxos) de cólera.

Ficamos verdes de medo... (Guiraud, 1991:64) 


\section{CAPÍTULO 4}

\section{ANÁLISE E DISCUSSÃO DOS RESULTADOS}

Feitas as abordagens dos autores que nortearam este estudo, cabe-nos agora apresentar e comentar algumas histórias produzidas pelas crianças. Começamos pelas histórias produzidas na situação (a), com apoio do desenho, e depois as histórias produzidas na situação (b), sem o apoio do desenho, mas com o suporte das histórias lidas pela pesquisadora.

Consideramos $\mathrm{P}$ para pesquisadora, e as demais inicias $\mathrm{Y}, \mathrm{M}, \mathrm{B}, \mathrm{J}, \mathrm{F}, \mathrm{V}$, para as crianças.

\section{I - Situação (a) - produção de histórias com apoio do desenho}

A situação I foi retirada da pesquisa transversal realizada em sala de leitura da pré-escola. Aqui, as crianças (5 anos) foram solicitadas pela pesquisadora a fazer um desenho, e depois contar uma história sobre o que tinham desenhado. As produções das narrativas foram desenvolvidas na interação da dupla de crianças e adulto-criança.

No primeiro encontro com as duas crianças, Y e M, inicialmente, apresentação pessoal coube à coordenadora da pré-escola, o que facilitou uma conversação sobre as atividades que as crianças desenvolviam no período que estavam na escola. Posteriormente, a coordenadora nos levou para a sala de leitura, onde havia almofadas, cadeiras e mesas para que pudéssemos realizar o trabalho. Então dialogamos sobre a atividade que elas iriam realizar (desenhar e depois contar uma história do mesmo desenho). Ambas ficaram entusiasmadas, e começaram a desenhar em folhas de sulfite, assim que terminaram o desenho, $\mathrm{Y}$ pediu para começar a contar e $\mathrm{M}$ ficou ouvindo a história do colega.

\section{Exemplo 1}

\section{Pássaro da paz}

1.Y: é porque é porque tinha muita guerra antes e o pássaro da paz veio e deu a paz

2.Y: é ... só ((risos))

3.M: (...) tentaram pegar (o pássaro) porque ele é muito bonzinho

4.P: (...) e o que o pássaro fez mais Yannick?

5.Y: é ele deu a paz brincou e depois foi dormir

(Yannick 5;0 e Mariana 5;0) 
Neste fragmento, o sujeito ao utilizar, no turno 1, o "porque" causal, justifica, explica e argumenta o fato narrado, corroborando assim a nossa hipótese, com base em Labov (1972), de que não há distinção fundamental entre explicação e narração, pois ao contar uma história a criança explica, e ao explicar, ela torna autêntico o caráter memorável daquilo que conta. Ainda aqui, notamos as EM “[...] o pássaro da paz veio e deu a paz”, em que o personagem (pássaro) quis e pôde realizar seu desejo, a paz. Com esta ação de benevolência, percebemos AI - em que o personagem se caracteriza como "bom".

Na segunda linha, temos a pausa, marcador conversacional - "é ... só"; seguido de outro marcador - o riso, recurso que, segundo Marcuschi (2003), é utilizado para finalizar a unidade comunicativa, e que Labov (1972) denomina de coda. De acordo com Rector e Trinta (1993), o riso (neste caso espontâneo) é considerado um gesto simples que serve para enfatizar o término da ação comunicativa.

Em 3, com a tomada de turno pela outra criança $M$, verificamos a elipse, o não preenchimento da casa do sujeito - "tentaram pegar (o pássaro) porque ele é muito bonzinho". De acordo com Possenti (1993), a elipse é a substituição por zero e serve para mostrar casos de indeterminação sintática resolvida por regras semânticas e discursivas. Identificamos, também, a avaliação encaixada, em que o narrador através do adjetivo "bonzinho" apresenta seu ponto de vista, sem interromper a ação de narrar.

Segundo F. François (1996), no turno 4, temos uma situação de tutela complementar, onde a pesquisadora faz uma pergunta sobre o desenho, e estimula a criança na continuidade narrativa, pois ela acrescenta novas informações por meio das ações do personagem no turno 5. E encerra a sua história recorrendo à coesão seqüencial temporal por meio da ordenação linear dos elementos sintáticos: "é ele deu a paz brincou e depois foi dormir". Paralelamente, encontramos o que Labov denomina de ação avaliativa - o narrador descreve o que o personagem fez, em vez de utilizar o discurso indireto; e a coda -a finalização/ moral da história.

De acordo com Mac-kay (2000), é comum a criança inserir em sua narrativa imaginária, fatos reais de seu cotidiano. Como essa história foi coletada em março (2003), época em que os EUA iniciou o ataque ao Iraque, podemos notar a inferência que a criança faz sobre os fatos da realidade cotidiana, ao intitular a história - Pássaro da paz, e através desta apresentar o seu desejo, o término dos ataques. 
No exemplo seguinte, (M) após ter ouvido, ansiosa, a história do "Pássaro da paz" de seu colega (Y), inicia sua narrativa.

\section{Exemplo 2}

\section{Alice no país das maravilhas}

1. M: ela ela abriu uma portinha caiu na maravilha viu um monte de borboleta e umas flores gravada com um sol BEM Longe... uma flor ela cheirou ... a outra arrancou e uma veio um tomate

2. M: (...) as nuvens redondas ... as nuvens redondas com um coração MARCADO

3. P: E o que Alice faz no país das maravilhas?

4. M: ela pega ... ela bate na porta ... ela cai lá e vai brincando e cai numa casinha e fica lá bem ... a casa é muito pequena ... e tinha uma porta que era falona

5. P: Hum porta falona e o que a porta falava?

6. M: falava ... você tem uma coisa que se chama cartão de CRÉdito pra por ne mim? e você entra Rápido ...e ela disse (Alice) por enquanto eu não peguei ... posso entrál rapidinho SÓ prál visiTÁ/ as minhas AMIigas? ai ela disse (porta falona) SÓ um POUquinho meia hora você sai ((a criança na mudança de personagem de Alice para a porta falona, aumenta o tom de voz e arregala os olhos))

7. (...) aí o relógio tava assim ... TRIM TRIM TRIM TRIM TRIM TRIM TRIM BLOM:... ... ai tava na hora dela ir embora ... ela falou (Alice)

boa tarde ... boa noite ... esqueci do boa tarde

(Mariana 5; 0)

No exemplo acima, no turno 1, de acordo com Labov, temos a ação avaliativa, o narrador inicia sua história descrevendo as ações do personagem em vez de relatar o que ele disse. Ainda aqui, observamos segundo F. François (1996), a presença do inesperado quando M para finalizar a seqüência de ações praticadas pelo personagem, insere o comentário: "e uma veio um tomate", ao invés de continuar elencando as ações do mesmo. Identificamos as EM "ela ela abriu uma portinha caiu na maravilha [...]”, por meio do querer e poder estar no maravilha. Em 2 “ (...) as nuvens redondas ... as nuvens redondas com um coração MARCADO”, notamos a avaliação encaixada (Labov), através dos adjetivos - redondas e marcado, que mostram o ponto de vista do narrador sem interromper a narração.

No turno 4, verificamos a substituição do termo "casa" pelo advérbio de lugar "lá"; segundo Kock (1997), o primeiro "lá", é elemento catafórico, pois se refere à palavra "casinha" que aparece posteriormente; e o segundo "lá", elemento anafórico, pois remete ao substantivo anteriormente mencionado. Também identificamos a avaliação encaixada, "a casa é muito pequena", ou seja, o narrador se posiciona diante 
do fato narrado, ao caracterizar a casa com o intensificador (muito) e o adjetivo (pequeno), sem suspender a ação de narrar.

De acordo com Bruner (1991), observamos uma situação de tutela de manutenção da orientação nos turnos 3 e 5 , em que a pesquisadora, por meio de perguntas, consegue manter a criança na continuidade narrativa. E o que François denomina de tutela complementar, pois a criança, na interação, adiciona novas informações ampliando seu discurso narrativo.

No turno 6 verificamos a ocorrência de DD, em que o narrador reproduz a fala dos dois personagens (porta falona - PF; Alice $-\mathrm{A}$ ), $\mathrm{PF}$ : “... você tem uma coisa que se chama cartão de CRÉdito pra por ne mim? e você entra Rápido ... [...] A: por enquanto eu não peguei ... posso entrá/ rapidinho SÓ prál visiTÁ/ as minhas AMIgas? [...] PF: SÓ um POUquinho meia hora você sai”. Neste discurso, notamos a variação da entonação da voz na mudança de personagem, juntamente com a modificação da fisionomia facial da criança ao arregalar os olhos, gesto que serve para enfatizar a comunicação-verbal, e que segundo Davis (1979) reflete o status do personagem, pois o dominador tende a olhar mais abertamente do que o subordinado, estabelecendo uma relação de domínio (porta falona) e submissão do EPP (Alice), na comunicação nãoverbal.

Neste caso, M faz inferência da realidade próxima, ao inserir em sua narrativa o "cartão de crédito", como vemos, ela assimila o discurso cotidiano do adulto pela convivência com ele. Segundo Mac-kay (2000:78-79):

A criança faz deslocamentos surpreendentes, dentro da história, argumentos que reforçam a carga de persuasão dos enunciados e que evidenciam seu desenvolvimento na posição de autora. Tais deslocamentos revelam uma realidade próxima a sua $[\ldots]$

No turno 7 verificamos o resultado (Labov), indicando uma causa (ai o relógio tava assim ... TRIM TRIM TRIM TRIM TRIM TRIM TRIM BLOM:.: ) / conseqüência (... aí tava na hora dela ir embora ...). E nesta relação de causa/conseqüência, notamos a explicação da criança, se pensarmos da seguinte forma: Alice tinha que ir embora "porque" o relógio já estava tocando. 
Nos exemplos 3 e 4, as crianças VH e F já tinham sido avisadas pela coordenadora da pré-escola que durante algumas sessões elas iram fazer uma atividade diferente, então ambas estavam preparadas para a tarefa, embora não soubessem ainda do que se tratava. Com o objetivo de tornar a atividade mais interessante, inicialmente, conversamos sobre o que elas gostavam de fazer na escola: brincar, desenhar, contar histórias. Após dialogarmos por um tempo, os materiais (sulfite, lápis de cor, canetinha) foram distribuídos para que as crianças desenhassem e depois contassem uma história sobre o desenho. Então, combinamos que quem terminasse o desenho primeiro, contaria a história. Logo, VH acabou e começou sua narrativa, enquanto $\mathrm{F}$ terminava seu desenho.

\section{Exemplo 3}

\section{A baleia}

1.VH: o golfinho foi lá na água ... ele viu uma baleia ENORME ... aí:..... ele foi lá na onde tinha os peixe ... ai ele comeu o peixe porque ele tava com fome aí aí ele ... viu o TUBARÃO que comeu um MONTE DE PEIXE aí ... ele comeu aí ele ( ) aí comeu o peixe ... ai veio o gigante ... comeu o peixe dele aí::.... o gigante deu um soco bem na baRRIGA dele ... ele caiu e ele morreu para sempre ... aí viveu de novo ((a criança faz gestos de soco no ar))

(Victor Hugo 5; 0)

Logo na primeira linha, de acordo com Labov (1972), temos a avaliação encaixada, o narrador informa seu ponto de vista - "baleia ENORME", sem interromper a ação de narrar. Na segunda linha, verificamos o elemento avaliativo explicativo (Labov) "porque" funcionando como um conectivo lógico para ligar duas proposições interdependentes, além de indicar, segundo o autor, o resultado - causa (ele estava com fome) / conseqüência (comeu o peixe). Por meio da ação do personagem (golfinho) de comer o peixe, percebemos as EM, em que ela quis e pôde saciar sua fome.

Assim, como no exemplo 2, aqui também identificamos a ação avaliativa, em que a criança conta sua história relatando uma seqüência de ações dos personagens.

$\mathrm{Na}$ linha 4, observamos a presença do inesperado ou mistura de mundos, de acordo com F. François (1996), a criança inicia sua narrativa com personagens que 
vivem no mar, e de repente insere o "gigante" que embora se assemelhe, pelo tamanho à baleia e ao tubarão, não faz parte desse universo marítimo.

Ao relatar o soco do gigante, $\mathrm{VH}$ gesticula murros no ar complementando sua fala. De acordo com Rector e Trinta (1993), quando a criança realiza tais ações corporais temos os gestos ilustradores, que servem para enfatizar a atividade verbal.

$\mathrm{Na}$ última linha "ele caiu e ele morreu para sempre ... aí viveu de novo", temos a coda (Labov), a finalização da história e ao mesmo tempo o inesperado (F. François) viver de novo.

Após $\mathrm{F}$ ter ouvido a história do colega, VH, e terminado seu desenho, inicia sua narrativa sobre o golfinho.

\section{Exemplo 4}

\section{O golfinho}

1. F: um golfinho ... o golfinho ... ele achô/ um ... e aí o golfinho ele tirôl ... depois caiu na pescaria aí ele falôl ... que quél isso? e aí apareceu um boné ... ai eles mergulharam ... o boné tava numa cabeça deles e ele foi nadando nadando e mergulhôl porque lá tinha um CARANGUEJÃO e apareceu um TUBARÃO e comeu tudo ... ele ficô/ pequenininho ...

2. P: quem o caranguejo?

3. F: a baleia comeu TUDO ... aí a baleia morreu aí ... acabôl

(Fernando 5; 0)

No turno 1, identificamos a ação avaliativa (Labov), o narrador descreve as ações dos personagens em vez de relatar o que disseram. Notamos também freqüentes pausas, indicando mudanças das ações do personagem (achô/; tirô/; caiu; falô/). A criança aqui, parece não saber ainda como conduzir sua história, por isso apresenta essa miscelânea de ações. De acordo com F. François (1996), na segunda linha ocorre o inesperado ou mistura de mundos, pois F inicia sua narrativa com "um golfinho" e depois acrescenta um objeto pertencente aos humanos -“um boné".

Segundo Mac-kay, a presença do boné mostra a inferência que a criança faz da realidade - sua vida cotidiana tornando autêntico seu posicionamento como autora. Ainda nesta linha, verificamos o resultado (Labov) - causa (apareceu um boné) / conseqüência (aí eles mergulharam). Na terceira linha, o "porque", estabelece relação do domínio do conteúdo, em que é apresentada a causa (tinha um caranguejão) para o 
fato (mergulhar). Como vemos, a explicação é um elo de causalidade e o "porque" funciona como um conectivo lógico, ligando duas proposições interdependentes.

No turno 2, verificamos uma situação de contra tutela (François), em que P faz uma pergunta "quem o caranguejo?", e a criança não responde, dando continuidade a sua narração no turno 3. Se pensarmos que foi o golfinho que "ficou pequenininho" ao invés do o caranguejo, então identificamos o EPP - a inferioridade do personagem principal. Ainda aqui, percebemos a avaliação encaixada (Labov) por meio do adjetivo pequenininho.

Em 3, fica claro que $\mathrm{F}$ realmente não queria continuar a atividade proposta, encerrando sua história - “a baleia comeu TUDO ... ai a baleia morreu aí ... acabô/ . Também aqui, de acordo com Labov, temos o resultado - causa (a baleia comeu tudo) / conseqüência (aí a baleia morreu); e nesta relação, identificarmos, implicitamente, a explicação da criança, quando justifica a morte da baleia; seguido da coda, finalização e moral da história, por meio dos verbos morreu e acabou.

Nos exemplos 5 e 6, as duas meninas B e J concordaram em participar da atividade proposta. Antes de inciarmos o trabalho, tanto $\mathrm{J}$ quanto B quiseram nos ensinar a música da borboletinha, que tinham aprendido com a professora da pré-escola. Depois de terem cantado a música, conversamos sobre o que elas deveriam fazer (desenhar e depois contar uma história sobre o desenho). Ambas entenderam, então os materiais (folhas de sulfite, lápis de cor, canetinha) foram distribuídos. Enquanto desenhavam, recitavam o poema da batatinha quando nasce... e cantavam variadas músicas da pré-escola. Durante a produção dos desenhos, B pediu para ir beber água, e quando voltou, trouxe uma pedrinha do jardim da escola dizendo que era para dar inspiração no momento da narração. Então, sorrimos e as duas continuaram pintando o desenho. Assim que terminaram, B começou sua narrativa, enquanto Jeniffer apontava o lápis. 


\section{Exemplo 5}

\section{As duas meninas sem braço}

1. B: as ...... duas meninas que chamava BIA e JENIFFER

2. B: (...) quando a gente ... ((Beatriz olha para Jeniffer que está apontando o lápis e diz)) ... OLHA $A$ SUJEIRA NA MESA ... daí::.... de repente viu um MONTE de estrela por aí e um bicho todo enrolado esse bicho era as:.:... (...) antes de andá/ com duas perna e dois braço as menina anda com um braço e uma perna ... de repente pareceu um TROSSO... é que ia fazê/ uma pedra aqui ... ((a criança aponta para a folha e desenha uma pedra))

3. B: de repente quando as duas viu a pedra aconteceu um acidente ... porque elas perderam a perna no bosque e o braço no bosque ... a outra menina perdeu a perna no bos/ na floresta e o braço na floresta ... as duas não foi junta só se encontraram ... a outra menina falou assim ...

4. B: oi gordINHA Jeniffer ((risos)) tudo bem? a Jeniffer falôl

tudo ... como que você...

a eu perdi meu bracinho no bosque ... você viu por aí? e a Jeniffer falôl

eu não por que?

porque ... é eu perdi (...) eu perdi um braço e uma perna ... NUM TÁ/ VENDO ... UÉ::....?

eu também perdi ... (braço e perna) na floresta ... você não viu por aí?

como que eu num vi ... eu vi por aí sim ... mas eu tava cum medo de pegál no seu osso ... ah se sabe que eu fico cum medo de você né?

Então vou te pegál ... INHAU ((a criança faz gestos de ataque para amedrontar a colega))

5. B: pronto

(Beatriz 5; 0)

No turno 1, segundo Labov (1972), verificamos as indicações - o narrador informa os personagens (no caso, Bia e Jeniffer). Em 2, quando B interrompe sua história para chamar a atenção da colega "OLHA A SUJEIRA NA MESA", temos avaliação externa (Labov), a criança interrompe a narrativa para expressar seus sentimentos em relação a atitude de J. Ainda neste fragmento, de acordo com Marcuschi (2003), identificamos na fala do narrador, marcadores conversacionais préposicionados: "olha" e "dai", que servem para orientar o ouvinte na interação. Então, B olhando para o desenho que havia feito, continua sua narração, "de repente viu um MONTE de estrela por aí e um bicho todo enrolado esse bicho era as:.....", observamos a pausa (Marcuschi, 2003) mudando o tópico discursivo (sobre o que se fala), pois a criança passou a falar sobre outro assunto: “(...) antes de andá/ com duas perna e dois braço as menina anda com um braço e uma perna" . Paralelamente, identificamos a ação avaliativa (Labov) - o narrador descreve as ações dos personagens.

Em “de repente apareceu um TROSSO”, de acordo com F. François (1996), temos o inesperado; e quando B diz "é que ia fazêl uma pedra aqui ...", temos, mais 
uma vez, avaliação externa - o narrador interrompe a ação de narrar para se posicionar diante do fato narrado.

No turno 3, notamos o resultado (Labov) - causa (acidente) / conseqüência (perda da perna e do braço). Também verificamos o conectivo "porque", funcionando como introdutor de justificação retroativa de uma enunciação explícita, ou seja, ele justifica a razão da perda do membro superior e inferior por meio do acidente.

Segundo Garcia (1988), no turno 4, verificamos a ocorrência de DD, em que o narrador reproduz a fala dos personagens, alterando a entonação de voz:

B: oi gordINHA Jeniffer ((risos)) tudo bem? a Jeniffer falôl

$\mathrm{J}$ : tudo ... como que você...

B: a eu perdi meu bracinho no bosque ... você viu por aí? e a Jeniffer falôl

$\mathrm{J}$ : eu não por que?

B: porque ... é eu perdi (...) eu perdi um braço e uma perna ... NUM TÁ/ VENDO ... $U \dot{E}:: . . . . ?$

$\mathrm{J}$ : eu também perdi ... (braço e perna) na floresta ... você não viu por aí?

B: como que eu num vi ... eu vi por aí sim ... mas eu tava cum medo de pegál no seu osso ... ah se sabe que eu fico cum medo de você né?

J: Então vou te pegál ... INHAU

Por meio desse diálogo, vemos sendo construída a narrativa, é o que Labov denomina de ação complicadora - o desenvolvimento da narração.

No fragmento do diálogo dos personagens, "a eu perdi meu bracinho no bosque ... você viu por aí? / e a Jeniffer falô/ / eu não por quê? / porque ... é eu perdi (...)" ; notamos a explicação pela pergunta de um dos personagens. De acordo com Veneziano et al. (2003), a criança inicialmente explica devido à solicitação de um outro (adulto). Constatamos, também, marcadores conversacionais no final da unidade comunicativa pós-posicionados - “... ué::.....?”; e “né??", orientando o interlocutor (no caso, o outro personagem) na continuidade discursiva (Marcuschi, 2003).

Ao final deste turno ((a criança faz gestos de ataque para amedrontar a colega)), observamos os gestos ilustradores (Rector e Trinta, 1993) que têm a função de enfatizar a comunicação verbal. No turno 5, a criança ao dizer "pronto" indica a coda (Labov) finalizando sua narrativa. 
Após ter participado e ouvido a história de $\mathrm{B}, \mathrm{J}$ inicia sua narrativa sobre $\mathrm{o}$ dinossauro, no exemplo que segue.

\section{Exemplo 6}

\section{Dinossauro}

1. J: SABIA::...... que um dinoSSAURO passava pela floresta ... o dinossauro era muito BRAvo ... que encontrô/ uma menina com ropa toda beje tudo ... quando encontrô/ o dinossauro ela falô/

2. J: oi ... senhor dinossauro tudo bem? ((a criança afina a voz))... ai ele falo/

TUDO ((a criança imita a voz do dinossauro))

3. J:O menino falô/ ... qual o seu nome? Ele falô/

É DINOSSAURO ué::..... aí ele (menino) falou

4. J: queria só sabel ... tchau tchau ((risos))

(Jeniffer $5 ; 0)$

No exemplo acima, no turno 1, a criança inicia sua narrativa informando sobre o personagem "dinossauro"que passeava pela floresta, segundo Labov (1972), temos as indicações, em que o narrador apresenta o lugar (floresta) e o personagem (dinossauro). Observamos a avaliação externa (Labov), “o dinossauro era muito BRAvo”, em que J por meio do intensificador "muito" e do adjetivo "bravo" interrompe a ação do narrar para expor seu ponto de vista. Paralelamente, este adjetivo indica AI - que o dinossauro por ser bravo, consegue dominar a situação, e conseqüentemente, constatamos as EM o personagem (dinossauro) quer e pode ser bravo.

$\mathrm{Na}$ continuidade narrativa... "que encontrô/ uma menina com ropa toda beje [...]", notamos a avaliação encaixada (Labov), por meio do adjetivo beje, o narrador não interrompe a ação de narrar para expor seu ponto de vista; em "quando encontrô/ o dinossauro ela falô/"..., identificamos a ação avaliativa (Labov) que consiste na descrição das ações dos personagens.

Entre os turnos 2 e 3, verificamos a ocorrência de DD com a mudança da entonação de voz para indicar a superioridade no dizer: TUDO ((a criança imita a voz do dinossauro)); e “É DINOSSAURO” , informando o EPP - a superioridade do personagem principal. Em 2, percebemos a ação complicadora (LABOV),o desenvolvimento da história e ao mesmo tempo o resultado, apresentação da causa (menina pergunta como ia o dinossauro) / conseqüência (o dinossauro responde que ia tudo bem) dos acontecimentos. Ainda em 3, constatamos, mais uma vez, por meio do 
diálogo entre o menino e o dinossauro o resultado - causa (pergunta do menino)/conseqüência (resposta do dinossauro). Também verificamos, segundo Labov, as indicações - apresentação de mais um personagem - o menino.

No turno 4, quando o menino diz "tchau tchau" ((risos)), temos a coda (Labov), finalização da história seguido de um marcador conversacional ((risos)), recurso que segundo Marcuschi (2003), é utilizado para finalizar a unidade comunicativa.

De acordo com teóricos da lingüística textual, a coesão é um dos princípios constitutivos da textualidade que se expressa sob forma de marcas lingüísticas na superfície do texto, assegurando sua continuidade, seqüência e unidade (Koch,1997; Marcuschi, 2003). Estas marcas podem ser expressas no texto sob a forma de conjunções (aditivas, continuativas, temporais, causais, adversativas), de referências anafóricas ou catafóricas (pessoal, demonstrativa, comparativa), de elipses e substituições.

No entanto, nem sempre estas marcas estão presentes nas narrativas infantis produzidas a partir de desenhos. Observamos que as histórias na situação (a), apresentam uma maior freqüência de referenciais extralingüísticos (gestos e ação de apontar).

Assim, as histórias parecem ser um complemento do desenho apresentado, cujo significado só pode ser atribuído em função do mesmo.

\section{II - Situação (b) - produção de narrativas a partir das histórias lidas pela pesquisadora}

A situação II foi extraída da pesquisa transversal realizada em sala de leitura da pré-escola, em situações interativas - adulto-criança e criança-criança. Inicialmente a pesquisadora contou duas histórias, "Fita Verde no cabelo: nova velha estória", de João Guimarães Rosa e "Menina bonita do laço de fita", de Ana Maria Machado. Após terem ouvido as duas narrativas, as crianças foram solicitadas pela pesquisadora a contar uma história. 
Nos exemplos 7 e 8 a seguir, como as duas crianças (Y e M) já nos conheciam, a interação foi mais fácil do que na situação (a). Assim que as duas histórias foram lidas, as crianças fizeram alguns comentários sobre os eventos de cada uma das narrativas, e depois contaram uma história.

\section{Exemplo 7}

\section{Os patinhos}

1.Y: era uma vez três patinhos que gostavam de passear todo dia na lagoa ... (...) é é eles também co ... é ...é...

2.P: o que eles gostavam de fazer?

3.Y: é de brincar e dormir ...

4.M: os três patinhos foram dormir ... existia o lobo ... lobo

5. P: o quê?

6. M: $L O-B O M A U$

7. M: (...) e aí o lobo mau ficava pá pá pá ((criança bate no chão)) ... o lobo olhou pela janela olhou pela portinha e ENTROU

8. Y: é ele entrou e comeu os três patinhos e a mãe não viu porque estava nas compras

9.M: (...) a mamãe tava só com filhotinho bem pequenininho ... ele (o filhotinho) olhou na barriga (do lobo) (...) veio o caçador e tirou todos os pintinho

(Yannick 5;0 e Mariana 5;0)

Diferentemente das ocorrências anteriores, nesta situação, sem o apoio do desenho, encontramos a construção típica do estilo narrativo: "era uma vez". No turno 1, as estruturas sintáticas apresentam seqüenciação por conexão através do pronome relativo que - "três patinhos que gostavam de passear na lagoa"; observamos as EMo "querer" e o "poder" passear na lagoa; verificamos também a pausa - "co ...é ... é", indicando a dificuldade ou falta de vontade do narrador para continuar a sua história. No entanto, a fim de auxiliá-lo na progressão da narrativa, $\mathrm{P}$ oferece, segundo Bruner (1991), uma situação de tutela de engajamento - motivação para a criança realizar a tarefa, através da pergunta no turno 2. No entanto, naquele momento ela não se mostrava disposta a dar continuidade a sua narrativa, quando responde no turno 3 , "é de brincar e dormir"; finalizando sua história. Podemos dizer então, que ocorreu uma situação de contra-tutela (François, 1996), pois a criança se desestimulou com a atividade.

Percebendo a reação de $\mathrm{Y}, \mathrm{M}$ resolve continuar a narrativa, e na troca de turno de um narrador para outro, observamos a mudança de tópico discursivo, isto é, o assunto inicial da narrativa foi modificado pela introdução de um novo personagem no turno 4, o lobo. Através da inferência do personagem mau da história de "Chapeuzinho 
Vermelho", M realiza a coesão recorrencial parafrástica, ao reformular parte da história de Perrault. Esta recorrência como cita Fávero (1999: 29): “contribui para a coesão do texto, já que atua como articuladora entre informações antigas e novas; distingue-se da repetição na medida em que possui uma característica importante: a criatividade”.

Notamos que essa inferência do lobo feita por M, possa ter ocorrido devido ao apoio contextual da primeira história lida - Fita Verde no Cabelo (Guimarães Rosa), considerada uma estilização de Chapeuzinho Vermelho, segundo Discini (2002:216217),

Fita-Verde ou Chapeuzinho Vermelho, em princípio, o mesmo ator, o mesmo papel actancial da narrativa, a mesma menina amada e linda, premiada com um adereço que constitui sua identificação, quis a aventura de encontrar-se consigo mesma, rompendo limites, à revelia do "outro".

Na linha 7, "e aí o lobo mau ficava pá pá pá ... o lobo olhou pela janela olhou pela portinha e ENTROU"; a utilização do conectivo - e, segundo Fiorin (2002), adiciona um dado novo (ações do lobo), indicando uma progressão semântica. Paralelamente identificamos a ação avaliativa (Labov), descrição das ações do personagem; quando a criança bate no chão, temos os gestos ilustradores (Rector e Trinta), que intensificam a atividade verbal. Observamos também, a repetição do termo "olhou", para dar continuidade e ênfase ao tópico em desenvolvimento.

No turno 8, temos a avaliação encaixada, em que a criança apresenta seu ponto de vista, sem suspender a ação de narrar, explicando a razão pela qual os patinhos foram comidos, tendo como referência à ausência da mãe: "é ele entrou e comeu os três patinhos e a mãe não viu porque estava nas compras". O "porque", neste caso é um conector que inicia um segmento de discurso, através do qual o falante introduz uma evidência (uma prova) que lhe permite tirar uma conclusão: se a mãe estivesse em casa tal fato, talvez não tivesse ocorrido. Como vemos, a criança faz inferência de seu conhecimento de mundo armazenado na memória, para chegar a determinadas conclusões. Ainda aqui, encontramos o que Labov (1972) denomina de resultado causa (ausência da mãe) / conseqüência (o lobo comeu os três patinhos).

Ao longo da história, percebemos o EPP - a inferioridade dos personagens principais (patinhos que foram comidos pelo lobo) que são mantidas; somente ao final 
em 9, M as substitui por pintinhos, estabelecendo o jogo lúdico por meio da troca dos personagens.

M, após ter ouvido a narrativa de seu colega, Y, inicia a sua história.

\section{Exemplo 8}

\section{Os coelhinhos}

1.M: era uma vez quatro coelhinhos eles gostavam de brincar um sobre o outro brincavam de danÇAR de puLAR ...

2.M: o Yannick pegou os quatro coelhinhos ... estava passando uma menina que se chamava Priscila ... a Priscila também quis um (coelho) ... eles era irmão ((Priscila e Yannick))

3.M: (...) a Priscila falô assim ... me dá um ... Yannick

4.M: ... AÍ ele falô assim ... nervoso como sempre... sua mãe (Mariana) disse ((a criança muda o tom de voz))

ONde que VOCÊS pegaram essas coisas ... esses coelhinhos? e aí ele disse ( )

5. M: (...) e ai os quatro coelhinhos gostavam de brincar um sobre o outro ... de novo eles brincaram de pula corda ... um...... um pulaVA de cabeça ... outro de joelho ... outro agatinhANDO ... todos brincavam pra lá e pra cá

6. Y: eles gostavam também de pula cela ... é um era bem velhinho tinha um que era MAIS velho e o dente já tava mole... já tava a ponto de cair... a mãe disse cuide bem desse dente que já já vai cair ((criança ao imitar a voz da mãe também aponta com o dedo indicador))

(Yannick 5;0 e Mariana 5;0)

Na primeira linha deste segmento, notamos a utilização da coesão recorrencial por meio do paralelismo que, segundo Fávero (1999), são estruturas reutilizadas, mas com diferentes conteúdos - "gostavam de brincar um sobre o outro brincavam de danÇAR de puLAR..." . Esta última parte (grifo nosso) corresponde à ação avaliativa (Labov), o narrador descreve as ações dos personagens, ao mesmo tempo, em que percebemos as EM - pois os personagens queriam e podiam brincar.

No turno 2, o narrador insere em sua narrativa as pessoas reais da interação (Yannick e Priscila). De acordo com Perroni (1992), essa técnica de "apoio no presente", uma das características dos casos (combinações livres em nível de discurso, onde não há compromisso com o enredo fixo nem com a verdade), cria uma realidade fictícia através da narrativa. No turno 3, observamos a ocorrência de DD, que o narrador transcreve o enunciado do personagem tal como foi formulado ou se imagina que foi: “a Priscila falô assim ... me dá um (coelhinho) Yannick”; aqui também temos a elipse o não preenchimento da casa do objeto. 
No turno 4, por meio do DD, identificamos a avaliação externa, cujo o narrador interrompe a narrativa para apresentar seu ponto de vista com a utilização do intensificador - "como sempre"; além da mudança do seu tom de voz para imitar a fala da mãe indicando a troca de personagem.

No turno 6, ocorre a troca de um narrador (M) para outro (Y), e aí verificamos a avaliação encaixada (Labov), por meio de elementos avaliativos - comparador "MAIS" e, ao mesmo tempo, a utilização da fonologia expressiva; como vemos, o narrador apresenta seu ponto de vista sem interromper a ação de narrar. Paralelamente temos AI - por meio da explicação da criança justificando o porquê do outro coelhinho ser mais velho (pois o dente já tava mole). De acordo com Hudelot et al. (2003) o termo "explicação" (mencionado na introdução) remete a um universo de sentidos, ou seja, para explicar o significado de uma palavra ou de uma ação, é necessário analisar o contexto e o sentido da mesma, sendo possível torná-la inteligível para o interlocutor.

Percebemos também que nessa idade ( 5 anos) é freqüente a criança inserir fatos de seu cotidiano na narrativa - a troca dos dentes. De acordo com Mac-kay (2000), tais deslocamentos revelam uma realidade próxima da criança e evidenciam a posição de autora no desenvolvimento narrativo.

No decorrer da história, diferentemente das ocorrências na situação (a), além do uso do pronome pessoal "ele" que contribui para a coesão recorrencial, observamos alguns elementos coesivos como o artigo indefinido "um", os pronomes "outro" e “todos" que substituem, segundo Fávero (1999), um termo procedente (anáfora) ou uma sucessão (catáfora). Neste caso, aqueles termos fazem referência à palavra coelhinho (s). Este recurso torna a narrativa não apenas coesa, mas também coerente.

Outro aspecto relevante a ser mencionado é a inferência (a presença de coelhinhos) que a criança faz sobre a segunda história lida - Menina Bonita do Laço de Fita (Ana Maria Machado), que trata da história do coelhinho que se apaixona por uma menina negra.

Os exemplos 9 e 10 foram coletados com $\mathrm{F}$ e $\mathrm{VH}$, os quais já estavam a espera desta atividade (ouvir e depois contar uma história), pois na última sessão, eles foram avisados que depois de duas semanas, contariam, novamente histórias. Então, foram 
lidas as duas histórias - Fita Verde no cabelo, e Menina Bonita do Laço de Fita, e depois $\mathrm{F}$ quis começar a narrar antes de $\mathrm{VH}$.

\section{Exemplo 9}

\section{A preta e o coelhinho}

1. F: era uma vez um coelhinho ... sempre queria ... ele queria ... é ... ele se apaixonôl aí ...

2. VH: parece que o Fernando tá mangando

3. F: vôo contál a história do futebol ... era uma vez dois homens jogando bola ... e aí um fez um gol ... e o outro deu a rasteira (...) naquele que fez o gol ... ai ele machucôl e foi pro médico ...e aí o médico falôl pra ele ficál LÁ UM TEMPÃO (...) ... mas papai chegôl lá e deixôl ele saíl porque ele já ia jogá./ bola ... e ai ele ficô/ machucado na perna (...) mas ele não se machucô/ (porque) a perna dele agora é DURA

4. VH: É DURA ((a criança faz gesto de admiração ao levantar a sobrancelha e arregalar os olhos))

5. F: o outro deu rasteira nele de novo mas ele não caiu porque ele é de FERRO e ai ele foi aquele que deu a surra nele foi para lá no CEARÁ...... aí ele cain em cima do sorvete e o sorvete tava QUENTE ... e agora ele parốl lá no céu ...

6. F: e ai acabô/

(Fernando 5;0 e Victor 5;0)

Assim como nos exemplos 7 e 8, aqui, a criança também inicia sua história com "era uma vez", fórmula típica do estilo narrativo. No turno 1, tomando como referência uma das histórias lidas pela pesquisadora, "Menina Bonita do Laço de Fita" (Ana Maria Machado), o narrador tenta recontar a narrativa ouvida, mas com freqüentes pausas, onde identificamos AI - o sentimento do personagem, quando $\mathrm{F}$ diz: "ele se apaixonô/”. Então, a outra criança $(\mathrm{VH})$ ao perceber a demora de (F) para dar continuidade a história, interrompe a narração no turno 2 , apresentando seu ponto de vista - avaliação externa (Labov) - "parece que o Fernando tá mangando".

No turno3, identificamos, de acordo com F. François (1996), uma situação de tutela complementar, que a partir do comentário de VH (embora não sendo de um adulto), F (no turno 3) toma a iniciativa de continuar o processo narrativo, porém com outro assunto, mudando o tópico discursivo - agora, o futebol. Segundo Labov (1972), temos aqui, a ação avaliativa - o narrador descreve as ações dos personagens. Além de verificarmos a coesão referencial (Fávero, 1999), através da substituição do termo homens pelos pronomes -"ele" e "outro"; e da reiteração - repetição do mesmo item lexical - "médicos", que é considerado por Labov um dos elementos avaliativos, ocorrido com freqüência no discurso oral. Também temos o explicativo - "porque", que justifica a permissão do pai para que o filho jogue bola. 
Em 4, observamos a fonologia expressiva - “É DURA”, presentes também nos turnos 3 - “LÁ UM TEMPÃO E DURA" e 5 - “FERRO, CEÁRA, QUENTE”. Ainda no turno 4, verificamos por meio da admiração da criança (ao arregalar os olhos), os gestos reguladores (Rector e Trinta), que sugerem ao emissor que continue a sua fala.

No turno 5, verificamos a ação complicadora (Labov), ou seja, o desenvolvimento da história, por meio do elemento conversacional "al" e do conectivo " $e$ " que servem para orientar o ouvinte e acrescentar informações novas, indicando uma progressão semântica. Em “ mas ele não caiu porque ele é de FERRO”, constatamos, mais uma vez, a explicação da criança para justificar o fato do garoto não ter caído, além da apresentação da causa (ele é de ferro) / conseqüência (por isso não caiu), que corresponde a uma das estruturas da narrativa proposta por Labov - o resultado. $\mathrm{Na}$ expressão “ e o sorvete tava QUENTE”, identificamos, ainda de acordo com o autor, a avaliação encaixada, onde o narrador insere seu ponto de vista sem interromper a ação de narrar.

E, por fim, no turno 6, temos o que Labov (1972) denomina de coda, o narrador informa para o seu interlocutor que a narrativa acabou.

Após ouvir a história do colega (F), VH pede para ir beber água antes de começar a sua narrativa. Quando volta para a sala, diz que já está pronto e pede para o colega prestar atenção.

\section{Exemplo 10}

\section{O pequeno urso}

1. VH: era uma vez o pequeno urso ... o pequeno urso sempre gostava de andál passeál andá/ passeál e ai o peixinho falô/ pra ele

2. VH: o pequeno urso você QUÉ/NADÁ/ com a gente? ... o pequeno urso falôl

3. VH: eu não quero ... porque o meu dente tál mole e aí o dente dele caiu e guardôl embaixo do travesseiro e a fada madrinha apareceu ... e ai ela falôl pra ele ir pra casa dormíl ...

4. VH: e ai ele bateu na porta ... e era o lobo que tava ... e o lobo comeu ele ... e o (gato) falou

5. VH: não você para aí ... e aí o gato escorregôl numa banana e chutôl o lobo e aí ele foi para lá na BEXIGA e a bexiga estorô/ na cara dele ...

6. P: e aí?

7. VH: e aí apareceu o leão e o tigre e aí acabôl

(Victor Hugo 5; 0) 
Logo no primeiro turno, observamos a presença do estilo narrativo "era uma vez...", seguido da avaliação encaixada (Labov), "o pequeno urso" em que o narrador, através do adjetivo, insere seu ponto de vista sem interromper a ação de narrar. $\mathrm{Na}$ primeira linha, identificamos as EM - o "querer e poder" passear. Verificamos, ainda de acordo com o autor, as indicações, a criança informa os personagens "urso" e "peixinho"; e a ação avaliativa, descrição das ações dos personagens, por meio dos verbos de ação (andá/ passeá/ falô/). Segundo F. François (1996), temos o inesperado, quando a criança, de repente, insere em sua narrativa um personagem (peixinho) que nada tinha a ver com o urso.

Nos turnos 2 e 3, observamos a ocorrência de DD, no qual o narrador transcreve o enunciado do personagem tal como foi formulado ou se imagina que foi, indicando a mudança na entonação da voz: "o pequeno urso você QUÉ/ NADÁ/ com a gente? ..." [...] ; “eu não quero ... porque o meu dente tá/ mole [...]”.

Segundo Leclaire-Halté (1990), a explicação em textos de ficção, surge quando há um problema de ordem cognitiva a ser resolvido, e no turno 3, identificamos o explicativo "porque", para justificar o motivo do urso não ir nadar, ou seja, ele tem um problema (dente mole) e por isso não pode nadar. Paralelamente temos o que Labov (1972) denomina de resultado, apresentação de uma causa (a pergunta do peixinho - “ $o$ pequeno urso você QUÉ/ NADÁ/ com a gente? ...") / conseqüência (resposta do pequeno urso - "eu não quero ..."). Na continuidade narrativa, "e aí o dente dele caiu e guardô/ embaixo do travesseiro e a fada madrinha apareceu ... e ai ela falo/ pra ele ir pra casa dormil ..., observamos o uso do conetivo - “e”, que adiciona novas informações, indicando uma progressão semântica (Fiorin, 2002), juntamente com a ação avaliativa (Labov), descrição das ações dos personagens.

Prosseguindo, no turno 4 ocorrem, novamente, as indicações (Labov), a introdução de personagens novos - o lobo e o gato. A presença do lobo nos mostra a inferência que a criança faz, a partir da primeira história lida (Fita Verde no Cabelo Guimarães Rosa), que é uma estilização da história de Perrault, ou seja, segue o mesmo enredo da história original (Chapeuzinho Vermelho), mas com algumas modificações.

De acordo com Labov (1972), no turno 5 “não você para aí ... e aí o gato escorregôl numa banana e chutôl o lobo e ai ele foi para lá na BEXIGA e a bexiga estorô/ na cara dele ...", temos a ação complicadora, o desenvolvimento da história, por 
meio da ação avaliativa (descrição das ações dos personagens), seguido do sinal conversacional - "aí”, que serve para orientar o ouvinte na assimilação de novas informações (Marcuschi, 2003).

Entre os turnos 6 e 7, identificamos uma situação de tutela com efeito inesperado (F. François, 1996), em que $\mathrm{P}$ faz a pergunta $e$ aí?, no intuito de estimular criança na continuidade narrativa, mas ela fornece uma resposta acrescentando novos personagens (e ai apareceu o leão e o tigre e aí acabô/), que nada tinha a ver com a seqüência dos turnos anteriores. Assim, a criança finaliza sua história "e aí acabô/", com a coda (Labov), uma das estruturas da narrativa que tem por finalidade indicar o fim da unidade comunicativa.

Os exemplos 11 e 12 se referem à produção de B e J. Sentamos nas almofadas da sala de leitura, enquanto as duas meninas se preparavam para ouvir as narrativas: Fita Verde no Cabelo e Menina Bonita de Laço de Fita; explicamos que assim que terminássemos de ler, elas contariam uma história. Então B disse que queria começar a contar antes de J, a qual concordou.

\section{Exemplo 11}

\section{Lala e Paulinho}

1. J: era uma vez ... uma menininha chamada Lala ... ela tinha um amigo chamado Paulinho e um dia eles dois se encontraram ... e foram pela floresta sozinho ... mas só que um dia eles tava cum medo de se perdêl eles foram pro caminho ERRADO ... porque eles foram do lado de lá ... aí eles se perderam ... num sabia onde era .. mais a casa ...

2. J: aí eles tinha medo de ficál sozinho pela floresta ... eles pensaram que tinha lobo mas NÃO TINHA ... tinha só animais que eram bonzinho ... e::..... apareceu um monte de animal que quando acendeu a luz apareceu um monte de animal (bum)

3. P: animal o que?

4. J: BOOM ... eles fazia careta pros dois ... aí:..... os dois achava medo aí eles tinha MEDO aí eles queria ir pra casa ( ) não sabia onde era ... mas a fada APARECEU e::..... a fada apareceu ... e deixô/ os animais lá embaixo e ficaram felizes para sempre

(Jeniffer $5 ; 0)$

Mais uma vez, no turno 1 , encontramos a característica da estrutura narrativa “era uma vez .....; seguido das indicações (Labov) - apresentação dos personagens (Lala e Paulinho); do lugar (floresta) e do tempo (um dia). 
Na continuidade narrativa, “... e foram pela floresta sozinho ... mas só que um dia eles tava cum medo de se perdêl eles foram pro caminho ERRADO ... porque eles foram do lado de lá ... ai eles se perderam", ainda de acordo com o autor, identificamos a avaliação encaixada, em que o narrador apresenta seu ponto de vista, sem interromper o ato narrativo quando relata $\mathbf{A I}$ - os sentimentos dos personagens - estar com medo; também, notamos, a ação avaliativa (Labov) - descrição das ações dos personagens.

Sobre o segmento citado, a criança quando utiliza o "porque", introduz uma evidência (uma prova) que justifica sua conclusão: o fato dos personagens terem ido pelo lado de lá, mais longe, a leva a crer que era o lado errado. Como percebemos, através das EM - os personagens quiseram e puderam escolher o caminho que lhe convinham. Aqui, a criança faz inferência a uma das histórias lidas -Fita Verde no Cabelo, cujo personagem também preferiu ir pelo caminho mais longo. Paralelamente, observamos o resultado (Labov) - causa (ir pelo caminho errado) / conseqüência (se perderam).

No turno 2, verificamos no início da unidade comunicativa o marcador conversacional - "ai’" que, segundo Marcuschi (2003), serve para orientar o ouvinte, além do conectivo - "e”, indicando uma progressão semântica no discurso. Esses recursos, de acordo com Labov (1972), contribuem para a ação complicadora - ou seja, para o desenvolvimento da história.

Segundo F. François (1996), temos uma situação de tutela complementar, no turno 3, quando $\mathrm{P}$ faz a pergunta e estimula a criança, em 4, na ampliação do discurso: “BOOM ... eles fazia careta pros dois ... aí::.... os dois achava medo ai eles tinha MEDO aí eles queria ir pra casa ( ) não sabia onde era ... mas a fada APARECEU e::.... a fada apareceu ... e deixô/ o os animais lá embaixo e ficaram felizes para sempre". Neste último fragmento (grifo nosso), notamos AI - os sentimentos dos personagens - ficar feliz, juntamente com a coda (Labov), que tem a função de finalizar a narrativa. Também observamos a ocorrência da fórmula típica de encerramento dos contos de fada (felizes para sempre), em que o bem sempre vence o mal. 
Após ter ouvido a história da colega (B), J solicitou que sentássemos nas cadeiras junto às mesas para que ela pudesse começar a contar a sua história. Feitas as mudanças de lugares, J iniciou sua narrativa.

\section{Exemplo 12}

\section{A menina e o coelho}

1. J: era uma vez ... uma menina era ADULTA ... que o nome dela era ... era:..... calma ai o coelhinho apareceu e todos adulto apareceu ... todos animais ... eles tava todo no cio ... mais a vovó ( ) animais ficava preso ... (...) que o moço do circo vendeu eles ... o moço do circo era um moço também era ... um moço ... o nome dele era Danilo

2. B: só porque tem o Danilo do pré né Jeniffer?

3. J: mas só que o ... era o Danilo o Danilo ...

4. P: é seu namorado?

5. J: Não

6. P: seu amigo?

7. ((a criança balança a cabeça dizendo que sim))

8. J: mas só que ele era do circo do ... do .. que mais do TREM mais todos tava no trem e ... uma corrente ia atrás porque tinha um MONTE DE TREM ... mas só ... todos passearam no trem ... o Danilo era MUITO BRAVO ... mas só que explodiu o trem e todo mundo morreu menos o dono do trem 9. P: e quem era o dono o Danilo?

10. J: é ... e foram lá pro céu ... e o amigo do Danilo eles era má também ...

11. P: e foram pro céu?

12. J: e eles foram lá pro outro trem e o outro trem também EXPLODIU e foram pro céu ... e só os animais ficaram triste ... acabôl

(Jeniffer 5;0)

No turno 1, ainda temos o estilo narrativo "era uma vez", seguido da avaliação externa (Labov) "calma ai", em que o narrador interrompe a ação de narrar para se posicionar diante do fato narrado. Ao fazer a pausa para organizar seu pensamento, o narrador insere em sua história novos personagens (coelho, adulto, animais, vovó e Danilo), que segundo Labov (1972) são as indicações.

No turno 2, “só porque tem o Danilo do pré né Jeniffer?", observamos a avaliação externa (Labov), em que a outra criança na interação se posiciona em relação ao que a colega está contando.

No turno 3, percebemos que $\mathrm{J}$ tem dificuldade de prosseguir com sua narrativa, assim, no turno 4, P faz uma pergunta para estimular a criança na narração, mas ela oferece resposta mínima - "não", temos, então, uma situação de tutela insistente (F. François, 1996).

Entre os turnos 6 P: seu amigo?; e 7 ((a criança balança a cabeça dizendo que sim)), observamos uma situação tutela paralela estrita em que o adulto faz o que a 
criança deveria fazer, pois ele fornece a reposta. Mesmo no turno 7, ocorrem os gestos ilustradores, que segundo Rector e Trinta (1993) servem para acompanhar e enfatizar a comunicação verbal.

No turno 8, verificamos a ação complicadora (Labov) - o desenvolvimento da história; o elemento avaliativo - explicativo "porque" funcionando como um conectivo lógico para ligar duas proposições interdependentes, além de indicar, segundo o autor, o resultado - causa ( um monte de trem) / conseqüência (uma corrente ia atrás). Em "o Danilo era MUITO BRAVO", ocorre a avaliação externa (Labov), em que o narrador, por meio do intensificador (muito) e do adjetivo (bravo), interrompe a narração para expor seu ponto de vista sobre o fato narrado; neste sentido identificamos, também, a AI - sentimento do personagem.

Como essa coleta foi realizada em março (2004), época em que aconteceu o atentado ao trem em Madri - Espanha e todos os passageiros morreram, percebemos a inferência da realidade cotidiana, na narrativa de J. De acordo com Mac-kay (2000): este deslocamento revela uma realidade próxima da criança, evidenciando sua posição de autora.

A seguir, no turno 9, registramos a ocorrência da tutela paralela estrita (F. François,1996), em que P, por meio da pergunta “e quem era o dono ... o Danilo?”, já fornece a resposta para a criança, fazendo o que esta deveria fazer.

No turno 12, quando J diz "acabô/", verificamos a coda (Labov), indicando a finalização do processo narrativo.

Considerando que a narrativa é um gênero de texto que possui uma unidade e significado delimitado por princípios de constituição bastante precisos, é possível especificar seu início, desenvolvimento e fim, através de características peculiares como: organização lingüística e componentes estruturais.

Neste sentido, as histórias produzidas nesta situação (b): sem o apoio do desenho, mas a partir de histórias lidas pela pesquisadora, apresentam construção típica do estilo narrativo "era uma vez..." , e independência contextual, ao contrário das histórias produzidas na situação(a). Além disso, devido ao apoio contextual das histórias lidas, as crianças frequentemente, recorrem a coesão recorrencial parafrástica, reformulando parte da narrativa ouvida. 
Diferentemente das ocorrências na situação (a), aqui, a manutenção do tópico discursivo, a continuidade das relações coesivas, por meio de conjunções (aditivas, continuativas, temporais, causais, adversativas), indicam uma progressão semântica no discurso em desenvolvimento (Fiorin, 2002).

Com base nos dados analisados, retomamos aqui, no quadro 3, os tipos de avaliação (Labov) levantados, no desenvolvimento das narrativas produzidas pelas crianças.

Quadro 3 - Tipos de avaliação em situações de narrativa oral (Labov)

\begin{tabular}{|l|lc|lr|}
\hline Tipos de Avaliação & \multicolumn{4}{|c|}{ Situações da narrativa } \\
\hline & Com apoio do desenho & \multicolumn{2}{l}{$\begin{array}{l}\text { Sem o apoio do desenho, } \\
\text { mas a partir de histórias } \\
\text { lidas pela pesquisadora }\end{array}$} \\
& $\mathrm{n}^{\mathrm{o} \text { de ocorrências }}$ & $\%$ & $\mathrm{n}^{\text {o de ocorrências }}$ & $\%$ \\
\hline Avaliação Externa & 4 & $26,66 \%$ & 5 & $29,41 \%$ \\
\hline Avaliação Encaixada & 5 & $33,34 \%$ & 5 & $29,41 \%$ \\
\hline Ação avaliativa & 6 & $40,00 \%$ & 7 & $41,18 \%$ \\
\hline Total & 15 & $100,00 \%$ & 17 & $100,00 \%$ \\
\hline
\end{tabular}

De acordo com o Quadro 3, verificamos que o elemento avaliação, aparece nas duas situações propostas: (a) com apoio do desenho; e (b) sem o apoio do desenho, mas a partir de histórias lidas pela pesquisadora.

A avaliação externa está presente mais nas produções da situação (b) com 5 ocorrências, equivalendo a $29,41 \%$ do total de freqüência nesta situação; e na situação (a) temos 4 ocorrências, ou seja, 26,66 \%.

Em relação à avaliação encaixada, temos 5 ocorrências tanto na situação (a) quanto na situação (b), mas devido ao total número de ocorrências, 15 em (a) e 17 em (b), temos 33,34 \% na primeira situação, e 29,41 \% na segunda situação. 
E constatamos, também, 6 ocorrências de ação avaliativa, na situação (a), correspondendo sobre o total de freqüência à 40,00 \%; e na situação (b) 7 ocorrências, correspondendo a $41,18 \%$.

Portanto, o número de ocorrências de avaliações nas duas situações, não é muito variável, pois as crianças apresentam elementos avaliativos, posicionando-se diante da narrativa, mostrando seus pontos de vista em relação ao fato narrado; ora suspendendo a ação de narrar, ora inserindo opiniões sem interromper o ato narrativo. 


\section{CAPÍTULO 5}

CONCLUSÕES

Este é o momento de (re)afirmar ou (re)pensar as intenções e comentar sucintamente o produto, estabelecendo na medida certa, a simbiose entre ambos. Poderíamos, dizer, que seria a última tentativa de convencer o leitor.

Cabe-nos, agora, retomar alguns pontos que nortearam nosso estudo: os corpora constituídos de doze narrativas orais, produzidos por crianças de 5 anos, estão distribuídos em duas situações (a) e (b), sendo seis narrativas para cada uma das situações, e compreendem uma análise qualitativa dos aspectos lingüísticos e discursivos neles observados.

Quanto às produções narrativas das crianças na situação (a), com apoio do desenho, verificamos que elas apresentam características típicas da linguagem oral, com elementos próprios do estilo conversacional, enunciados fragmentados, freqüentes pausas, elipses, e, portanto, dependentes da representação pictográfica, na medida em que as crianças olhavam e apontavam para o desenho durante o desenvolvimento da história, ou seja, elas buscaram no desenho o apoio contextual necessário para veicular as informações. Desse modo, as histórias, aqui produzidas, embora não apresentem elementos lingüísticos explícitos (por exemplo, era uma vez; então; depois entre outros) que contribuem para a coesão e coerência do texto, observamos que estes estariam no desenho, que a criança se inspirou para desenvolver a sua narrativa.

A partir daí, constatamos que o desenho pode auxiliar as crianças na produção de histórias, pois elas não precisam usar elementos lingüísticos explícitos para explicarem a razão de suas narrativas, devido ao apoio da representação pictográfica.

As histórias produzidas na situação (b), a partir de narrativas lidas pela pesquisadora, apresentam características da linguagem escrita, independência contextual e construções próprias do estilo narrativo: era uma vez... . A continuidade temática, estabelecendo a coesão e coerência textual, é o resultado da utilização de recursos como: apresentação de acontecimentos e ações cujos conteúdos semânticos deram conta da progressão e, neste caso, os marcadores "daí", “aí", e “e”, foram usados como elementos de reforço a essa continuidade, mesmo que repetidas vezes, parece ser uma estratégia das crianças para dar progressão a narrativa; seqüencialização temporal das 
ações e/ou acontecimentos; recorrência aos tempos verbais: pretérito para indicar o gênero narrativo; repetição dos marcadores conversacionais "aí" e "olha", enquanto marcas das estratégias de progressão textual.

O uso de pausa, retomada-modificação, marcadores de seqüência, discurso reportado e a seleção dos elementos coesivos sinalizaram o processo de constituição dos sujeitos na posição de autor.

Nesta situação (b), percebemos que as narrativas lidas pela pesquisadora estimularam as crianças a produzirem histórias, compostas de um esquema narrativo completo, indicando começo, meio e fim, através de elementos lingüísticos explícitos (era uma vez, então, daí...), semelhantes aos que aparecem nas histórias que elas ouviram, antes de iniciar a atividade proposta. Contribuindo, assim, para aprimorar a qualidade narrativa das histórias produzidas por elas.

A partir destas diferenças constatadas nas duas situações, podemos concluir que a qualidade narrativa da história produzida pelas crianças varia segundo a situação em que elas são solicitadas a elaborar sua produção.

Em relação a compreensão e produção de histórias, retomamos agora, alguns conceitos para verificarmos como estas habilidades se desenvolvem na mente da criança.

De acordo com Fayol (1982), se compreender uma narrativa significa construir uma representação mental, assimilando os elementos que a constituem em uma estrutura de conhecimento prévio, assim, as crianças captam um discurso narrativo porque possuem em sua consciência o esquema pré-construído, juntamente com um conjunto de representações; assim, compreender é, em partes, reconhecer e operar (fazer inferências) sobre uma espécie de esquema armazenada na memória com a ajuda de informações vindas da história, que se tem contato; e se produzir história, significa acionar a representação mental da estrutura narrativa armazenada na memória, então, verificamos que compreender e produzir são habilidades relacionadas entre si; e também, confirmamos uma de nossas hipóteses levantadas na introdução deste estudo, de que a compreensão de histórias parece preceder a sua produção.

Percebemos esta seqüência: compreensão e produção de narrativas, através dos corpora aqui apresentados: na situação (b), de maneira mais explícita, as crianças compreendem/codificam na memória as informações vindas das narrativas lidas pela 
pesquisadora, e depois utilizam a inferência de seus conhecimentos de mundo e lingüístico armazenado na memória para (re)criá-las na produção de suas histórias; na situação (a), também observamos a existência de um esquema narrativo (já armazenado na memória), pois as crianças narram fatos (com apoio do desenho), fazendo inferências sobre eventos cotidianos.

Por meio dos dados coletados, observamos que todas as histórias, tanto na situação (a) quanto na situação (b), apresentam o elemento avaliativo - em que o narrador se posiciona durante o processo narrativo para expressar seu ponto de vista, ora suspendendo a ação de narrar, ora inserindo opiniões sem interromper a narração. Como vemos, esta estratégia que o narrador emprega para mostrar o propósito de sua história, sua razão de existir, indica porque ele conta e aonde quer chegar. E ao se posicionar, diante do fato narrado, ele também explica, utilizando justificativas e argumentos para tornar sua história mais interessante.

Portanto, os aspectos explicativo e narrativo encontram-se articulados nas histórias orais produzidas pelas crianças, confirmando assim a hipótese levantada por nós no início deste trabalho, de que estes dois aspectos são o cerne da produção de narrativas e a razão principal para que elas se tornem significativas. Além de evidenciarmos o valor argumentativo que o contar explicando adquire na construção dialógica. 


\section{BIBLIOGRAFIA}

ADAM, J. M. Le texte narratif. Paris: Nathan-Université, 1985.

ALVAREZ, A. M. M. Deu branco. São Paulo: Best Seller, 2002.

ARTONI, A L. Caracterização de narrativas de crianças de cinco e seis anos: correlações entre episódios e ações. Dissertação de Mestrado em Ciências dos distúrbios de Comunicação. Universidade Federal de São Paulo - Escola Paulista de Medicina, São Paulo, 2001.

BREMOND, C. Le message narratif. In: Communication, Paris, 4:4-32, 1966.

BRIDGES, A. Comprehension strategies reconsidered: the evidence of individual patterns of response. Journal of Child Language, 7:89-104, 1980.

BRUNER, J. Atos de significação. Trad. Sandra Costa. Porto Alegre: Artes Médicas, 1997.

Le rôle de l'interaction de tutelle dans la resolution de problèmes. In: Le développement de l'enfant: savoir faire, savoir dire. 3 ed. Paris: PUF, 1991.

CHOMSKY, N. Aspects of the theory of syntax. Cambridge:Mass, 1965.

DAVIS, F. A comunicação não-verbal. São Paulo: Summus, 1979.

DE VILLERS, J. G.; DE VILLERS, P. A. Competence and performance in child language: are children really competent to judge? Journal of Child Language, 1:11-22, 1973.

DISCINI, N. Intertextualidade e conto maravilhoso. São Paulo: HumanitasFFLCH/USP, 2002.

ELLIOT, A. J. A linguagem da criança. Trad. Vera Ribeiro. Rio de Janeiro: Zahar Editores, 1982.

FÁVERO, L. L.Coesão e coerência textuais. São Paulo: Ática, 1999. 
FAYOL, M. Le récit et sa construction: une approche de la psychologie cognitive. Paris: Delachaux e Niestlé, 1982.

FERREIRA, S. Imaginação e linguagem no desenho da criança. $3^{\mathrm{a}}$ ed. São Paulo: Papirus, 1998.

FIORIN, J. L.; SAVIOLI, F. P. Para entender o texto: leitura e redação. $16^{\circ}$ ed. São Paulo: Ática, 2002.

FLAVELL, J. H.; MILLER, P. H.; MILLER, S. A. Desenvolvimento cognitivo. Trad. Claudia Dornelles. $3^{\text {a }}$ ed. Porto Alegre: Artmed, 1999.

FRANÇOIS, F. Práticas do oral: diálogo, jogo e variações das figuras do sentido. Trad. Lélia Erbolato Melo. São Paulo: Pró-Fono, 1996.

FREUD, S. Edição standart brasileira das obras psicológicas completas de Sigmund Freud. Rio de Janeiro: Imago Editorial, 1987.

GARCIA, O. M. Comunicação em prosa moderna: aprenda a escrever, aprendendo a pensar. 14ª ed. Rio de Janeiro: Fundação Getúlio Vargas, 1988.

GARCIA-ROZA, L. A. Freud e o inconsciente. $19^{\text {a }}$ ed. Rio de Janeiro: Jorge Zahar, 2002.

GARDNER, H. A criança pré-escolar: como pensa e como a escola pode ensiná-la. Porto Alegre: Artes Médicas, 1994.

GENETTE, G. Discours du récit. In: Figures III. Paris: Éditions du Seuil, 1972.

GREIMAS, A. J. Sémantique structurale. Paris: Larousse, 1964.

GUIMARÃES, E. A articulação do texto. $4^{\mathrm{a}}$ ed. São Paulo: Ática, 1995.

GÜILICH, E. et UTA QUASTHOFF. Narrative analysis. Dans Teun Aa. Van Dijk (dir), Handbook of discourse analysis. London: Academic Press, p.169-192.

GUIRAUD, P. A linguagem do corpo. Trad. Lólio Lourenço de Oliveira. São Paulo: Ática, 1991.

HISADA, S. A utilização de histórias no processo psicoterápico: uma proposta winnicottiana. Rio de Janeiro: Revinter, 1998. 
HUDELOT, C.; PRÉNERON,C.; ORVIG, A. Explicações, distância e interlocução na criança de dois a quatro anos. In: FERNANDES. Aquisição da linguagem: conceito, definição e explicação na criança. Araraquara: Cultura Acadêmica, 2003.

KARMILOFF -SMITH, A. Language as a formal problem space for children. Paper prepared for the MPG/NIAS Conference on Beyond Description in Child Language, 11-16, Holland, 1979.

KOCK, I. V. A coesão textual. São Paulo: Contexto, 1997.

e TRAVAGLIA, L. C. A coerência textual. São Paulo: Contexto, 1997.

LABOV, W. La transformation du vécu à travers la syntaxe narrative. Le parler ordinaire, la langue des ghettos noirs des États-Unis. Paris: Minuit, 1972.

LACAN, J. O seminário livro 11: os quatro conceitos fundamentais da psicanálise. Rio de Janeiro: Jorge Zahar Editores, 1993.

LAFOREST, M.; VICENT, D. Du récit littéraire à la narration quotidienne. In: Autour de la narration - les abords du récit conversationnel. Québec (Canadá), Nuit Blanche Éditeur, 1996.

LECLAIRE-HALTÉ, A. Explication et récit dans les textes de fiction. Pratiques, Paris, 67:15- 34, 1990.

LINS; SILVA, M. E; SPINILLO, A. G. Uma análise comparativa da escrita de histórias por alunos de escolas públicas e particulares. Revista Brasileira de Estudos pedagógicos, 79 (193): 5-16, 1998.

LUQUET, G. H. O desenho infantil. Portugal: Minho, 1969.

MACHADO, A. M. Menina bonita do laço de fita. São Paulo: Ática, 1997.

MAC-KAY, A. P. Atividade verbal: processo de diferença e integração entre fala escrita. São Paulo: Plexus, 2000.

MARCUSCHI, L. A. Análise da conversação. $5^{\circ}$ ed. São Paulo: Ática, 2003. 
MASSINI-CAGLIARI, G. O texto na alfabetização: coesão e coerência. Campinas: editora da Autora, 1997.

MAYRINK-SABINSON, M. T. Compreensão e produção. Boletim 3, ABRALIN: 138$149,1982$.

MELO, L. E. Le rôle de l'évaluation dans le récit. CAlap, Paris, 20:.25-44, 2000.

MOREIRA, A. A. O espaço do desenho: a educação do educador. $8^{\mathrm{a}}$ ed. São Paulo: Loyola, 1999.

PERRONI, M. C.Desenvolvimento do discurso narrativo. São Paulo: Martins Fontes, 1992.

PIAGET, J.; INHELDER, B. A psicologia da criança. Trad. Octavio Mendes Cajado. $14^{\mathrm{a}}$ ed. Brasil: Bertrand, 1995.

POSSENTI, S.Discurso, estilo e subjetividade. São Paulo: Martins Fontes, 1993.

PRETI, D.; URBANO, H. A linguagem falda culta na cidade de São Paulo: Projeto NURC/SP. São Paulo: Queiroz, 1990.

PROPP, V. Morphology du conte. Paris: Ëditions du Seuil, 1970. 1997. . As raízes históricas do conto maravilhoso. São Paulo: Martins Fontes,

RECTOR, M. e TRINTA, A. R. Comunicação do corpo. $2^{\mathrm{a}}$ ed. São Paulo: Ática, 1993.

REGO, L.B. A escrita de estórias por crianças: as implicações pedagógicas do uso de um registro lingüístico . D.E.L.T.A., São Paulo, 2:65-82, 1986.

ROSA, J. G. Fita verde no cabelo: nova velha estória. $4^{\mathrm{a}}$ ed. Rio de Janeiro: Nova Fronteira, 1992.

SALEH, P. Narrativas infantis sobre experiências vividas: uma questão de reprsentação? Tese de Doutorado em Lingüística. Universidade Estadual de Campinas/UNICAMP, São Paulo, 2000.

SPINILLO, A. O efeito da representação pictográfica na produção de narrativas. In: Psicologia: Teoria e Pesquisa. Brasília, 7, 3: 311-326, 1991. 
e PINTO, G. Children's narratives under different conditions: a comparative study. British Journal of Developmental Psychology, 12: 177-193, 1994.

A produção de histórias por crianças: a textualidade em foco. In: CORREA, J. , SPINILlO, A. e LEITÀO, S. Desenvolvimento da linguagem: escrita e textualidade. Rio de Janeiro: Nau Editora, 72- 86, 2001.

TANNEN, D. Oral and literate strategies in spoken and written narratives. Language, 58: 1-21, 1982.

TODOROV, T. Poétique de la prose. Paris: Ëditions du Seuil, 1971.

VAN DIJK, T. A. Cognição, discurso e interação. Kock,I. V. (org.). São Paulo: Contexto, 1992.

VAN DIJK, T. A. \& KINTSCH, W. Strategies of discourse comprehension. New York: Academic, 1983.

VENEZIANO, E. et al. Construção e reconstrução das condutas explicativas. In: FERNANDES, S. D. (org). Aquisição da linguagem: conceito, definição e explicação na criança. Araraquara: FLC/Laboratório Editorial/UNESP. São Paulo: Cultura Acadêmica, 39-68, 2003.

VYGOTSKY, L. S. A formação social da mente. Trad. José Cipola Neto. São Paulo: Martins Fontes, 1991.

WINNICOTT, D.W. O brincar e a realidade. Trad. José Octávio de Aguiar Abreu. Rio de Janeiro: Imago, 1975. 
ANEXOS 


\section{ANEXO 1 - NORMAS PARA TRANSCRIÇÃO}

\begin{tabular}{|c|c|c|}
\hline OCORRÊNCIAS & SINAIS & EXEMPLIFICAÇÃO* \\
\hline $\begin{array}{l}\text { Incompreensão de } \\
\text { palavras ou segmentos }\end{array}$ & ( ) & $\begin{array}{l}\text { do nível de renda...( ) } \\
\text { nível de renda nominal... }\end{array}$ \\
\hline $\begin{array}{l}\text { Hipótese do que se } \\
\text { ouviu }\end{array}$ & (hipótese) & $\begin{array}{l}\text { (estou) meio preocupado } \\
\text { (com o gravador) }\end{array}$ \\
\hline $\begin{array}{l}\text { Truncamento (havendo } \\
\text { homografia, usa-se } \\
\text { acento indicativo da } \\
\text { tônica e/ou timbre) }\end{array}$ & I & e comé/ e reinicia \\
\hline Entoação enfática & maiúscula & $\begin{array}{l}\text { porque as pessoas } \\
\text { reTÊM moeda }\end{array}$ \\
\hline $\begin{array}{l}\text { Prolongamento de vogal } \\
\text { e consoante (como s, r) }\end{array}$ & $\begin{array}{l}:: \text { podendo aumentar } \\
\text { para ::.:: ou mais }\end{array}$ & $\begin{array}{c}\text { ao emprestarem os... } \\
\text { éh..: ...o dinheiro }\end{array}$ \\
\hline Silabação & - & por motivo tran-sa-ção \\
\hline Interrogação & $?$ & $\begin{array}{c}\text { eo Banco... Central... } \\
\text { certo? }\end{array}$ \\
\hline Qualquer pausa & $\ldots$ & $\begin{array}{l}\text { são três motivos... ou três } \\
\text { razões... que fazem com } \\
\text { que se retenha moeda... } \\
\text { existe uma... retenção }\end{array}$ \\
\hline $\begin{array}{l}\text { Comentários descritivos } \\
\text { do transcritor }\end{array}$ & ((minúsculas $))$ & $(($ tossiu $))$ \\
\hline $\begin{array}{l}\text { Comentários que } \\
\text { quebram a seqüência } \\
\text { temática da exposição; } \\
\text { desvio temático }\end{array}$ & -- -- & $\begin{array}{c}\text {... a demanda de moeda - } \\
\text { - vamos dar essa notação } \\
\text {-- demanda de moeda } \\
\text { por motivo }\end{array}$ \\
\hline
\end{tabular}




\begin{tabular}{|c|c|c|}
\hline OCORRÊNCIAS & SINAIS & EXEMPLIFICAÇÃO* \\
\hline $\begin{array}{c}\text { Superposição, } \\
\text { simultaneidade de } \\
\text { vozes }\end{array}$ & $\{$ ligando as linhas & $\begin{array}{l}\text { A. na } \text { \{ casa da sua irmã } \\
\text { B. sexta-feira? } \\
\text { A. fizeram }\{\text { lá... } \\
\text { B. cozinharam } \\
\text { lá? }\end{array}$ \\
\hline $\begin{array}{l}\text { Indicação de que a fala } \\
\text { foi tomada ou } \\
\text { interrompida em } \\
\text { determinado ponto. Não } \\
\text { no seu início, por } \\
\text { exemplo. }\end{array}$ & $(\ldots)$ & $\begin{array}{c}\text { (...) nós vimos que } \\
\text { existem... }\end{array}$ \\
\hline $\begin{array}{l}\text { Citações literais ou } \\
\text { leituras de textos, } \\
\text { durante a gravação }\end{array}$ & " " & $\begin{array}{l}\text { Pedro Lima... ah escreve } \\
\text { na ocasião... "O cinema } \\
\text { falado em língua } \\
\text { estrangeira não precisa } \\
\text { de nenhuma baRREIra } \\
\text { entre nós"... }\end{array}$ \\
\hline & & \\
\hline
\end{tabular}

\section{Observações:}

1. Iniciais maiúsculas: só para nomes próprios ou para siglas (USP etc.)

2. Fáticos: ah, éh, eh, ahn, ehn, uhn, tá (não por está: tá? você está brava?)

3. Nomes de obras ou nomes comuns estrangeiros são grifados.

4. Números: por extenso.

5. Não se indica 0 ponto de exclamação (frase exclamativa). 6. Não se anota o cadenciamento da frase.

7. Podem-se combinar sinais. Por exemplo: oh:...... (alongamento e pausa) 8. Não se utilizam sinais de pausa, típicos da língua escrita, como ponto-evírgula, ponto final, dois pontos, vírgula. As reticências marcam qualquer tipo de pausa, conforme referido na Introdução.

PRETI, D.; URBANO, H. (orgs.). A linguagem falada culta na cidade de São Paulo.São Paulo: T. Aa.. Queiroz/Fapesp,1990.p.7-8. 


\section{ANEXO 2 - OS CORPORA \\ I - Situação (a) - produção de histórias com apoio do desenho}

\section{Exemplo 1}

\section{Pássaro da paz}

1.Y: é porque é porque tinha muita guerra antes e o pássaro da paz veio e deu a paz

2.Y: é ... só ((risos))

3.M: (...) tentaram pegar (o pássaro) porque ele é muito bonzinho

4.P: (...) e o que o pássaro fez mais Yannick?

5.Y: é ele deu a paz brincou e depois foi dormir

( Yannick 5;0 e Mariana 5;0)

\section{Exemplo2}

\section{Alice no país das maravilhas}

1. M: ela ela abriu uma portinha caiu na maravilha viu um monte de borboleta e umas flores gravada com um sol BEM Longe... uma flor ela cheirou ... a outra arrancou e uma veio um tomate

2. M: (...) as nuvens redondas ... as nuvens redondas com um coração MARCADO

3. P: E o que Alice faz no país das maravilhas?

4. M: ela pega ... ela bate na porta ... ela cai lá e vai brincando e cai numa casinha e fica lá bem ... a casa é muito pequena ... e tinha uma porta que era falona

5. P: Hum porta falona e o que a porta falava?

6. M: falava ... você tem uma coisa que se chama cartão de CRÉdito pra por ne mim? e você entra Rápido ...e ela disse (Alice) por enquanto eu não peguei ... posso entrál rapidinho SÓ prál visiTÁ/ as minhas AMIigas? aí ela disse (porta falona) SÓ um POUquinho meia hora você sai ((a criança na mudança de personagem de Alice para a porta falona, aumenta o tom de voz e arregala os olhos))

7. (...) aí o relógio tava assim ... TRIM TRIM TRIM TRIM TRIM TRIM TRIM BLOM::: ... ai tava na hora dela ir embora ... ela falou (Alice)

boa tarde ... boa noite ... esqueci do boa tarde

(Mariana 5;0) 


\title{
Exemplo 3
}

\begin{abstract}
A baleia
1.V: o golfinho foi lá na água ... ele viu uma baleia ENORME ... aí::.... ele foi lá na onde tinha os peixe ... ai ele comeu o peixe porque ele tava com fome ai aí ele ... viu o TUBARÃO que comeu um MONTE DE PEIXE aí ... ele comeu ai ele ( ) aí comeu o peixe ... aí veio o gigante ... comeu o peixe dele aí:..... o gigante deu um soco bem na baRRIGA dele ... ele caiu e ele morreu para sempre ... ai viveu de novo ((a criança faz gestos de soco no ar))
\end{abstract}

(Victor Hugo 5; 0)

\section{Exemplo 4}

\section{O golfinho}

1. F: um golfinho ... o golfinho ... ele achô/ um ... e aí o golfinho ele tirôl ... depois caiu na pescaria ai ele falôl ... que quél isso? e aí apareceu um boné ... aí eles mergulharam ... o boné tava numa cabeça deles e ele foi nadando nadando e mergulhôl porque lá tinha um CARANGUEJÃO e apareceu um TUBARÃO e comeu tudo ... ele ficô/ pequenininho ...

2. P: quem o caranguejo?

3. F: a baleia comeu TUDO ... aí a baleia morreu aí ... acabôl

(Fernando 5;0)

\section{Exemplo 5}

\section{As duas meninas sem braço}

1. B: as :..... duas meninas que chamava BIA e JENIFFER

2. B: (...) quando a gente ... ((Beatriz olha para Jeniffer que está apontando o lápis e diz)) ... OLHA A SUJEIRA NA MESA ... daí::.... de repente viu um MONTE de estrela por ai e um bicho todo enrolado esse bicho era as:..... (...) antes de andál com duas perna e dois braço as menina anda com um braço e uma perna ... de repente pareceu um TROSSO... é que ia fazê/ uma pedra aqui ... ((a criança aponta para a folha e desenha uma pedra)) 
3. B: de repente quando as duas viu a pedra aconteceu um acidente ... porque elas perderam a perna no bosque e o braço no bosque ... a outra menina perdeu a perna no bos/ na floresta e o braço na floresta ... as duas não foi junta só se encontraram ... a outra menina falou assim ...

4. B: oi gordINHA Jeniffer ((risos)) tudo bem? a Jeniffer falôl tudo ... como que você...

a eu perdi meu bracinho no bosque ... você viu por aí? e a Jeniffer falô/ eu não por que?

porque ... é eu perdi (...) eu perdi um braço e uma perna ... NUM TÁ/ VENDO ... $U E ́:: \ldots . . . ?$

eu também perdi ... (braço e perna) na floresta ... você não viu por aí?

como que eu num vi ... eu vi por aí sim ... mas eu tava cum medo de pegál no seu osso ... ah se sabe que eu fico cum medo de você né?

Então vou te pegál ... INHAU ((a criança faz gestos de ataque para amedrontar a colega))

5. B: pronto

(Beatriz 5;0)

\section{Exemplo 6}

\section{Dinossauro}

1. J: SABIA::..... que um dinoSSAURO passava pela floresta ... o dinossauro era muito BRAvo ... que encontrô/ uma menina com ropa toda beje tudo ... quando encontrôl o dinossauro ela falô/

2. J: oi ... senhor dinossauro tudo bem? ((a criança afina a voz))... aí ele falô/ TUDO ((a criança imita a voz do dinossauro))

3. J:O menino falô/ ... qual o seu nome? Ele falô/

É DINOSSAURO ué::..... ai ele (menino) falou

4. J: queria só sabel ... tchau tchau ((risos))

(Jeniffer 5; 0) 
II - Situação (b) - produção de narrativas a partir de histórias lidas pela pesquisadora

\section{Exemplo 7}

\section{Os patinhos}

1.Y: era uma vez três patinhos que gostavam de passear todo dia na lagoa ... (...) é é eles também co ... é ... é ...

2.P: o que eles gostavam de fazer?

3.Y: é de brincar e dormir ...

4.M: os três patinhos foram dormir ... existia o lobo ... lobo

5. P: o quê?

6. M: $L O-B O M A U$

7. M: (...) e aí o lobo mau ficava pá pá pá ((criança bate no chão)) ... o lobo olhou pela janela olhou pela portinha e ENTROU

8. Y: é ele entrou e comeu os três patinhos e a mãe não viu porque estava nas compras

9.M: (...) a mamãe tava só com filhotinho bem pequenininho ... ele (o filhotinho) olhou na barriga (do lobo) (...) veio o caçador e tirou todos os pintinho

(Yannick 5;0 e Mariana 5;0)

\section{Exemplo 8}

\section{Os coelhinhos}

1.M: era uma vez quatro coelhinhos eles gostavam de brincar um sobre o outro brincavam de danÇAR de puLAR ...

2.M: o Yannick pegou os quatro coelhinhos ... estava passando uma menina que se chamava Priscila ... a Priscila também quis um (coelho) ... eles era irmão ((Priscila e Yannick))

3.M: (...) a Priscila falô assim ... me dá um ... Yannick

4.M: ... AÍ ele falô assim ... nervoso como sempre... sua mãe (Mariana) disse ((a criança muda o tom de voz))

ONde que VOCÊS pegaram essas coisas ... esses coelhinhos? e ai ele disse ( )

5. M: (...) e ai os quatro coelhinhos gostavam de brincar um sobre o outro ... de novo eles brincaram de pula corda ... um.:.... um pulaVA de cabeça ... outro de joelho ... outro agatinhANDO ... todos brincavam pra lá e pra cá

6. Y: eles gostavam também de pula cela ... é um era bem velhinho tinha um que era MAIS velho e o dente já tava mole... já tava a ponto de cair... a mãe disse cuide bem desse dente que já já vai cair ((criança ao imitar a voz da mãe também aponta com o dedo indicador))

(Yannick 5;0 e Mariana 5;0) 


\section{Exemplo 9}

\section{A preta e o coelhinho}

1. F: era uma vez um coelhinho ... sempre queria ... ele queria ... é ... ele se apaixonô/ aí...

2. V: parece que o Fernando tá mangando

3. F: vôo contál a história do futebol ... era uma vez dois homens jogando bola ... e aí um fez um gol ... e o outro deu a rasteira (...) naquele que fez o gol ... ai ele machucô/ $e$ foi pro médico ...e aí o médico falôl pra ele ficál LÁ UM TEMPÃO (...) ... mas papai chegôl lá e deixôl ele saíl porque ele já ia jogá./ bola ... e aí ele ficôl machucado na perna (...) mas ele não se machucô/ (porque) a perna dele agora é DURA

4. V: É DURA ((a criança faz gesto de admiração ao levantar a sobrancelha e arregalar os olhos))

5. F: o outro deu rasteira nele de novo mas ele não caiu porque ele é de FERRO e aí ele foi aquele que deu a surra nele foi para lá no CEARÁ...... ai ele caiu em cima do sorvete e o sorvete tava QUENTE ... e agora ele parô/ lá no céu ...

6. F: e aí acabô/

(Fernando 5;0 e Victor 5;0)

\section{Exemplo 10}

\section{O pequeno urso}

1. VH: era uma vez o pequeno urso ... o pequeno urso sempre gostava de andá/ passeál andál passeál e ai o peixinho falô/ pra ele

2. VH: o pequeno urso você QUÉ/NADÁ/ com a gente? ... o pequeno urso falôl

3. VH: eu não quero ... porque o meu dente tál mole e aí o dente dele caiu e guardôl embaixo do travesseiro e a fada madrinha apareceu ... e ai ela falôl pra ele ir pra casa dormil ...

4. VH: e ai ele bateu na porta ... e era o lobo que tava ... e o lobo comeu ele ... e o (gato) falou

5. VH: não você para aí ... e aí o gato escorregôl numa banana e chutôl o lobo e aí ele foi para lá na BEXIGA e a bexiga estorôl na cara dele ...

6. P: e aí?

7. VH: e aí apareceu o leão e o tigre e aí acabô/

(Victor Hugo 5; 0) 


\section{Exemplo 11}

\section{Lala e Paulinho}

1. J: era uma vez ... uma menininha chamada Lala ... ela tinha um amigo chamado Paulinho e um dia eles dois se encontraram ... e foram pela floresta sozinho ... mas só que um dia eles tava cum medo de se perdêl eles foram pro caminho ERRADO ... porque eles foram do lado de lá ... ai eles se perderam ... num sabia onde era .. mais a casa ...

2. J: aí eles tinha medo de ficál sozinho pela floresta ... eles pensaram que tinha lobo mas NÃO TINHA ... tinha só animais que eram bonzinho ... e::..... apareceu um monte de animal que quando acendeu a luz apareceu um monte de animal (bum)

3. P: animal o que?

4. J: BOOM ... eles fazia careta pros dois ... aí::.... os dois achava medo aí eles tinha MEDO ai eles queria ir pra casa ( ) não sabia onde era ... mas a fada APARECEU e::.... a fada apareceu ... e deixô/ os animais lá embaixo e ficaram felizes para sempre

(Jeniffer 5; 0)

\section{Exemplo 12}

\section{A menina e o coelho}

1.J: era uma vez ... uma menina era ADULTA ... que o nome dela era ... era:.:... calma ai o coelhinho apareceu e todos adulto apareceu ... todos animais ... eles tava todo no cio ... mais a vovó ( ) animais ficava preso ... (...) que o moço do circo vendeu eles ... o moço do circo era um moço também era ... um moço ... o nome dele era Danilo

2. B: só porque tem o Danilo do pré né Jeniffer?

3. J: mas só que o ... era o Danilo o Danilo ...

4. P: é seu namorado?

5. J: Não

6. P: seu amigo?

7. ((a criança balança a cabeça dizendo que sim))

8. J: mas só que ele era do circo do ... do .. que mais do TREM mais todos tava no trem e ... uma corrente ia atrás porque tinha um MONTE DE TREM ... mas só ... todos passearam no trem ... o Danilo era MUITO BRAVO ... mas só que explodiu o trem e todo mundo morreu menos o dono do trem

9. P: e quem era o dono o Danilo?

10. J: é ... e foram lá pro céu ... e o amigo do Danilo eles era má também ...

11. P: e foram pro céu?

12. J: e eles foram lá pro outro trem e o outro trem também EXPLODIU e foram pro céu ... e só os animais ficaram triste ... cabol 


\section{ANEXO 3 - MATERIAL UTILIZADO}

\section{Fita Verde no Cabelo}

Havia uma aldeia em algum lugar, nem maior nem menor, com velhos que velhavam, homens e mulheres que esperavam, e meninos e meninas que nasciam e cresciam. Todos com juízo, suficientemente, menos uma meninazinha, a que por enquanto. Aquela, um dia saiu de lá, com uma fita verde inventada no cabelo.

Sua mãe mandara-a, com um cesto e um pote, à avó, que a amava, a uma outra e quase igualzinha aldeia. Fita-Verde partiu, sobre logo, ela a linda, tudo era uma vez. O pote continha um doce em calda, e o cesto estava vazio, que para buscar framboesas.

Daí, que indo, no atravessar o bosque, viu só os lenhadores, que por lá lenhavam; mas o lobo nenhum, desconhecido nem peludo. Pois os lenhadores tinham exterminado o lobo.

Então, ela, mesma, era quem dizia:

$\square$ Vou à vovó, com cesto e pote, e a fita verde no cabelo, o tanto que a mamãe mandou.

A aldeia e a casa esperando-a acolá, depois daquele moinho, que a gente pensa que vê, e das horas, que a gente não vê que não são. E ela mesma resolveu escolher tomar este caminho de cá, louco e longo, e não o outro, encurtoso. Saiu, atrás de suas asas ligeiras, sua sombra também vindo-lhe correndo, em pós. Divertia-se com ver as avelãs no chão não voarem, com inalcançar essas borboletas nunca em buquê nem em botão, e com ignorar se cada uma em seu lugar as plebeinhas flores, princesinhas e incomuns, quando a gente tanto por elas passa. Vinha sobjadamente.

Demorou, para dar com a avó em casa, que assim lhe respondeu, quando ela, toque, toque, bateu:

\section{- Quem é?}

- Sou eu... e Fita-Verde descansou a voz.

-- Sou sua linda netinha, com o cesto e pote, com a fita verde no cabelo, que a mamãe me mandou.

Vai, a avó, difícil e disse:

-- Puxa o ferrolho de pau da porta, entra e abre. Deus te abençoe. 
Fita-Verde assim fez, e entrou e olhou. A avó estava na cama, rebuçada e só. Devia de falar agagado e fraco e rouco, assim, de ter apanhado um ruim defluxo. Dizendo:

- Depõe o pote e o cesto na arca, e vem para perto de mim, enquanto é tempo. Mas agora Fita-Verde se espantava, além de entritecer-se de ver que perdera em caminho sua grande fita verde no cabelo atada; e estava suada, com enorme fome de almoço. Ela perguntou:

-- Vovozinha, que braços tão magros, os seus, e que mãos tão trementes!

-- É porque não vou poder nunca mais te abraçar, minha neta... a avó murmurou.

-- Vovozinha, mas que lábios, aí, tão arroxados!

-- É porque não vou nunca mais poder te beijar, minha neta... a avó suspirou.

-- Vovozinha, e que olhos tão fundos e parados, nesse rosto encovado, pálido?

-- É porque já não te estou vendo, nunca mais, minha netinha... a avó ainda gemeu.

Fita-Verde mais se assustou, como se fosse ter juízo pela primeira vez. Gritou:

-- Vovozinha eu tenho medo do lobo!...

Mas a avó não estava mais lá, sendo que demasiado ausente, a não ser pelo frio, triste e tão repentino corpo.

ROSA, G. J. Fita verde no cabelo: nova velha estória. $4^{\mathrm{a}}$ ed. Rio de Janeiro: Nova Fronteira, 1992. 
Menina bonita do laço de fita

Era uma vez uma menina linda, linda. Os olhos dela pareciam duas azeitonas pretas, daquelas bem brilhantes. Os cabelos eram enroladinhos e bem negros, feito fiapos da noite. A pele era escura e lustrosa, que nem o pêlo da pantera negra quando pula na chuva.

Ainda por cima, a mãe gostava de fazer trancinhas no cabelo dela e enfeitar com laço de fita colorida. Ela ficava parecendo uma princesa das Terras da África, ou uma fada do Reino do Luar.

Do lado da casa dela morava um coelho branco, de orelha cor-de-rosa, olhos vermelhos e focinho nervoso sempre tremelicando. O coelho achava a menina mais linda que ele tinha visto em toda sua vida. E pensava:

- Ah, quando eu casar quero ter uma filha pretinha e linda que nem ela...

Por isso, um dia ele foi até a casa da menina e perguntou:

- Menina bonita do laço de fita, qual é o teu segredo pra ser tão pretinha?

A menina não sabia, mas inventou:

- Ah, deve ser porque eu caí na tinta preta quando era pequenina...

O coelho saiu dali, procurou uma lata de tinta preta e tomou banho nela. Ficou bem negro, todo contente. Mas aí veio a chuva e lavou todo aquele pretume, ele ficou branco outra vez.

Então ele voltou lá na casa da menina e perguntou outra vez:

- Menina bonita do laço de fita, qual é o teu segredo pra ser tão pretinha?

A menina não sabia, mas inventou:

- Ah, deve ser porque eu tomei muito café quando era pequenina.

O coelho saiu dali e tomou tanto café que perdeu o sono e passou a noite toda fazendo xixi. Mas não ficou nada preto.

Então ele voltou lá na casa da menina e perguntou outra vez:

- Menina bonita do laço de fita, qual é o teu segredo pra ser tão pretinha?

A menina não sabia, mas inventou:

- Ah, deve ser porque eu comi muita jabuticaba quando era pequenina. 
O coelho saiu dali e se empanturrou de jabuticaba até ficar pesadão, sem conseguir sair do lugar. O máximo que conseguiu foi fazer muito cocozinho preto e redondo feito jabuticaba. Mas não ficou nada preto.

Por isso, daí a alguns dias ele voltou lá na casa da menina e perguntou outra vez:

- Menina bonita do laço de fita, qual é o teu segredo pra ser tão pretinha?

A menina não sabia e já ia inventando outra coisa, uma história de feijoada, quando a mãe dela, que era uma mulata linda e risonha, resolveu se meter e disse:

- Artes de uma avó preta que ela tinha...

Aí o coelho - que era bobinho, mas nem tanto - viu que a mãe da menina devia estar mesmo dizendo a verdade, porque a gente se parece sempre é com os pais, os tios, os avós e até com os parentes tortos.

E se ele queria ter uma filha pretinha e linda que nem a menina, tinha era que procurar uma coelha preta para se casar.

Não precisou procurar muito. Logo encontrou uma coelhinha escura como a noite, que achava aquele coelho branco uma graça.

Foram namorando, casando e tiveram uma ninhada de filhotes, que coelho quando desanda a ter filhote não pára mais. Tinha coelho pra todo gosto: branco bem branco, branco meio cinza, branco malhado de preto, preto malhado de branco e até uma coelha bem pretinha. Já se sabe, afilhada da tal menina bonita que morava na casa ao lado.

E quando a coelhinha saía, de laço colorido no pescoço, sempre encontrava alguém que perguntava:

- Coelha bonita do laço de fita, qual é o teu segredo pra ser tão pretinha?

E ela respondia:

- Conselhos da mãe da minha madrinha...

MACHADO, A. M. (1997). Menina bonita do laço de fita. São Paulo: Ática. 


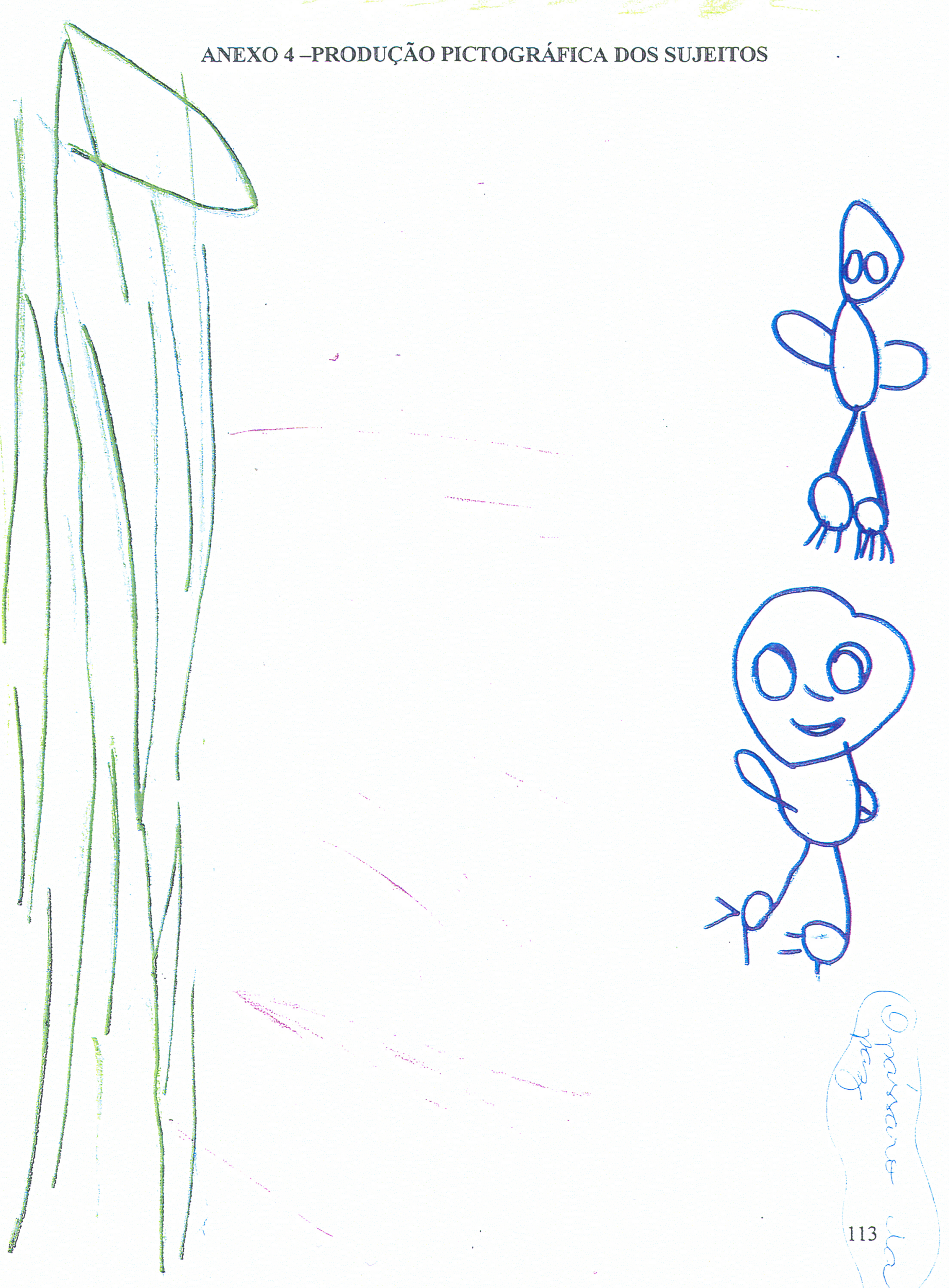




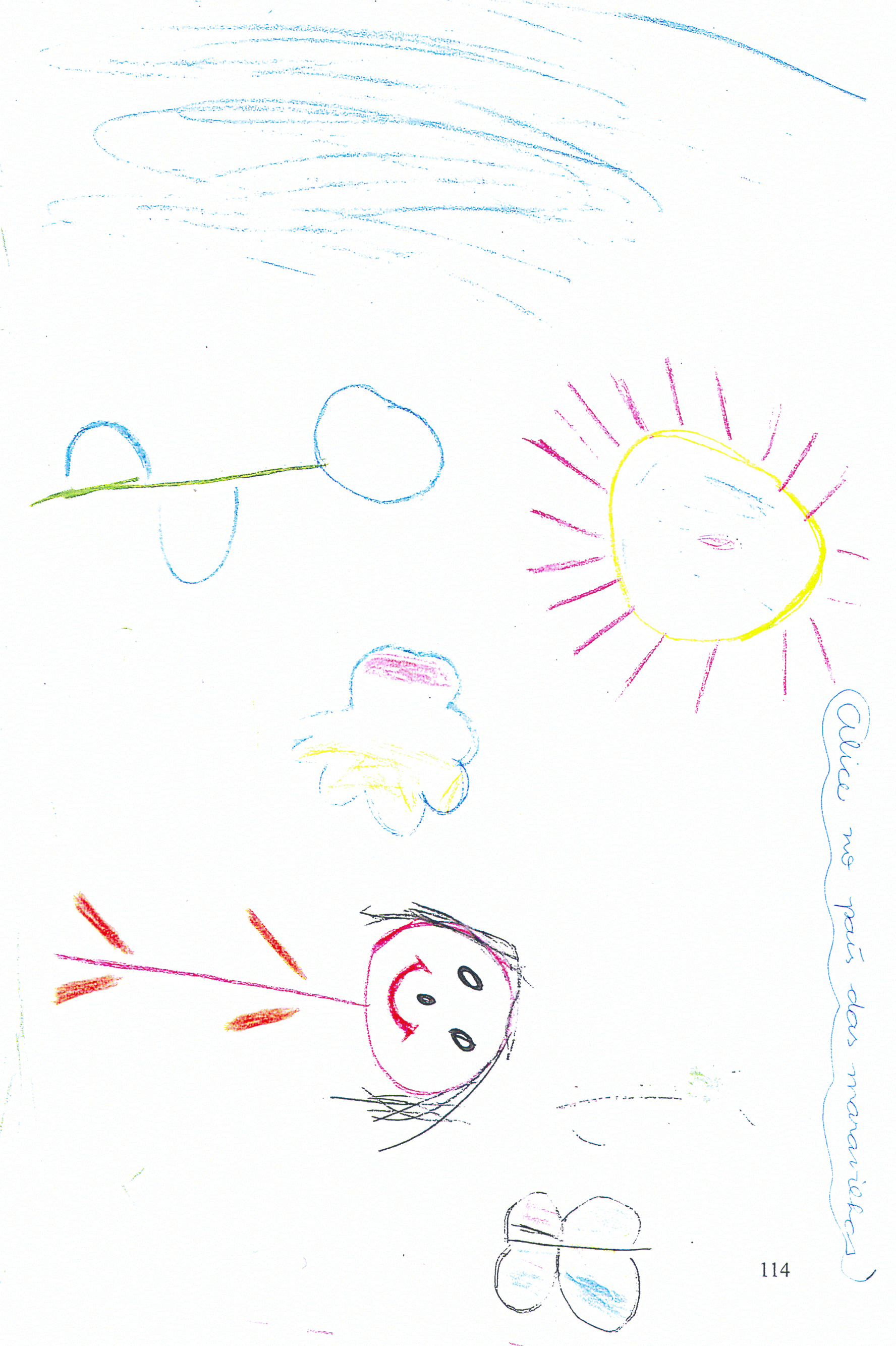





$$
\text { FERNANDO GOLFINHO }
$$

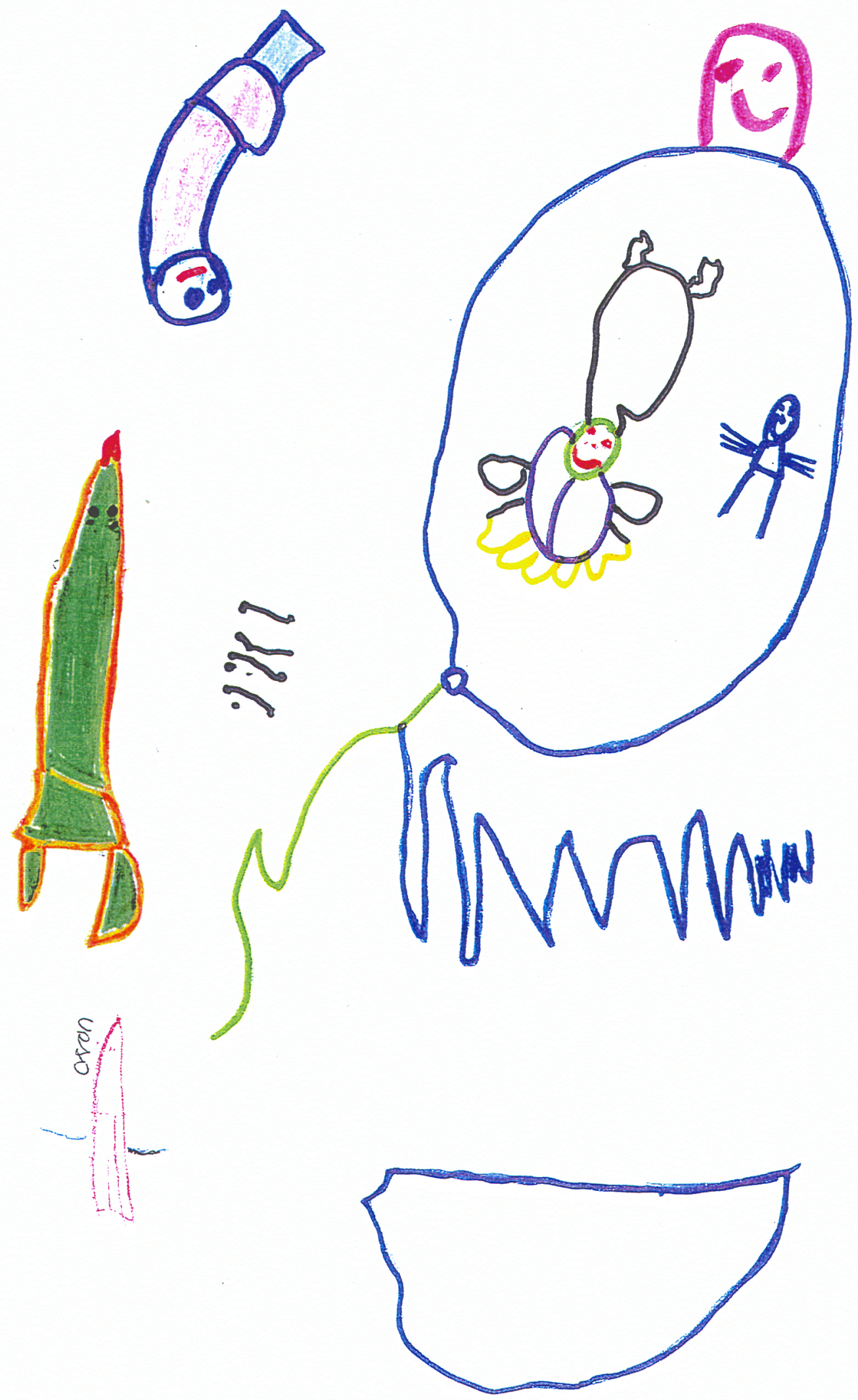




\section{As duas menunas sem braco}

,

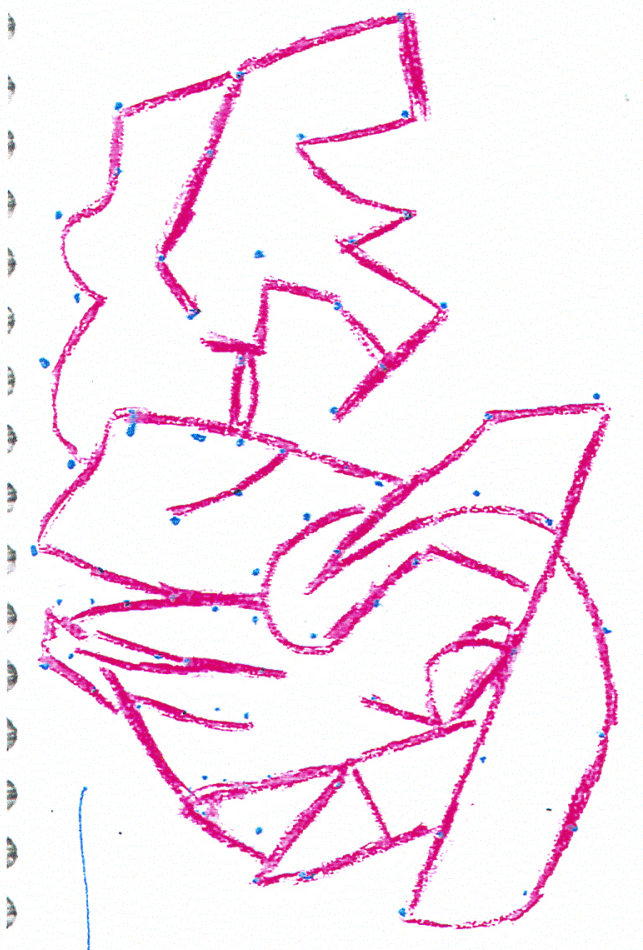

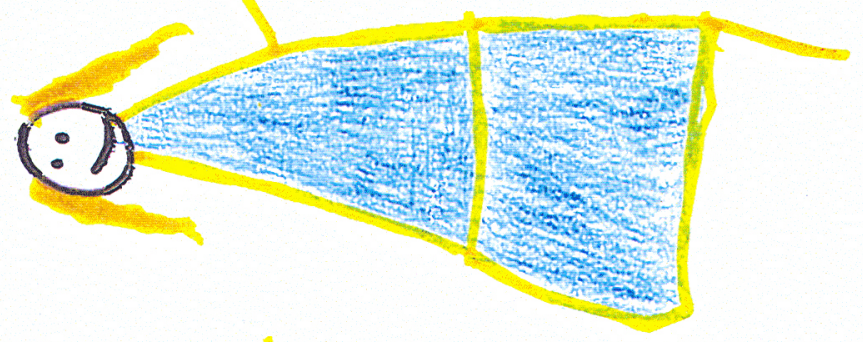

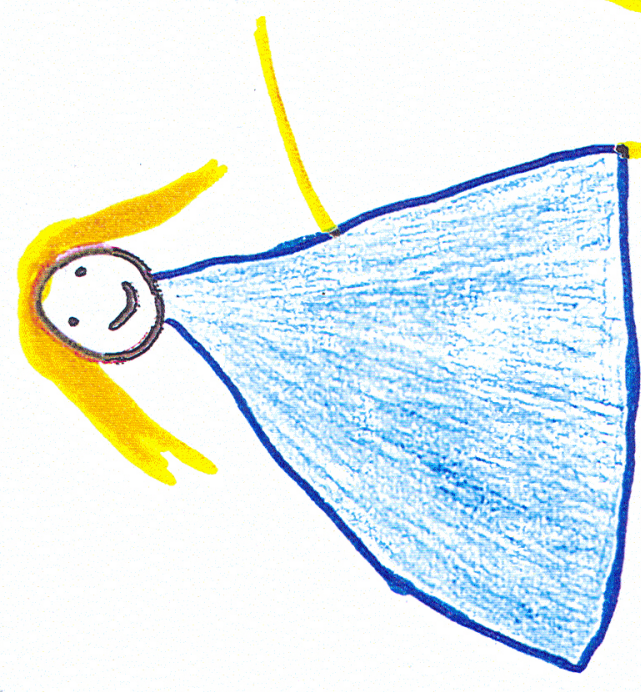


$\xi$

$\Theta$ dinossauro

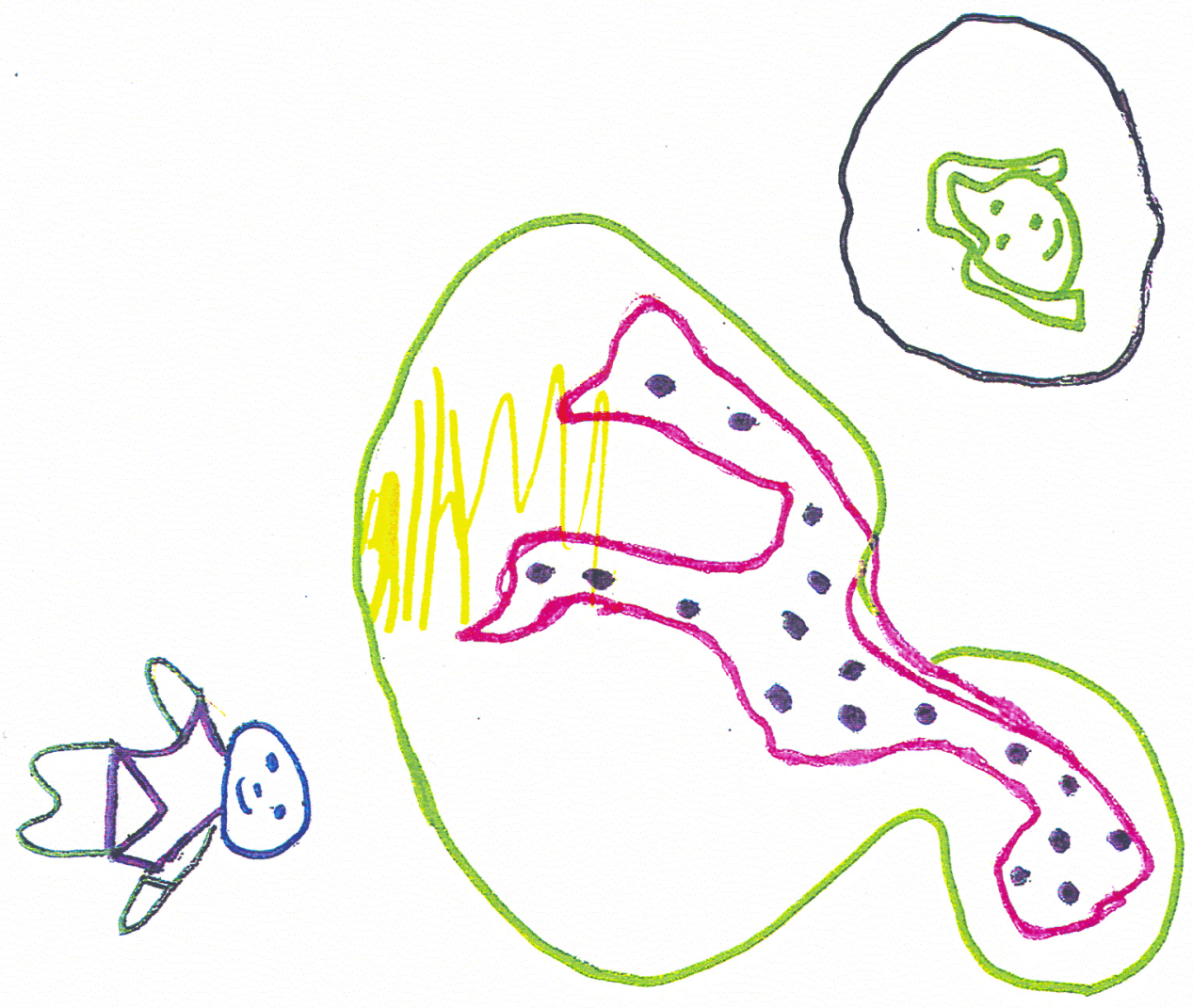

118 